\title{
WestVirginiaUniversity
}

THE RESEARCH REPOSITORY @ WVU

Graduate Theses, Dissertations, and Problem Reports

2017

\section{Three Essays on International Mobility and Economic Development}

Imran Arif

Follow this and additional works at: https://researchrepository.wvu.edu/etd

\section{Recommended Citation}

Arif, Imran, "Three Essays on International Mobility and Economic Development" (2017). Graduate Theses, Dissertations, and Problem Reports. 5121.

https://researchrepository.wvu.edu/etd/5121

This Dissertation is protected by copyright and/or related rights. It has been brought to you by the The Research Repository @ WVU with permission from the rights-holder(s). You are free to use this Dissertation in any way that is permitted by the copyright and related rights legislation that applies to your use. For other uses you must obtain permission from the rights-holder(s) directly, unless additional rights are indicated by a Creative Commons license in the record and/ or on the work itself. This Dissertation has been accepted for inclusion in WVU Graduate Theses, Dissertations, and Problem Reports collection by an authorized administrator of The Research Repository @ WVU.

For more information, please contact researchrepository@mail.wvu.edu. 


\title{
Three Essays on International Mobility and Economic Development
}

\author{
Imran Arif \\ Dissertation submitted to the \\ College of Business and Economics \\ at West Virginia University \\ in partial fulfillment of the requirements \\ for the degree of \\ Doctor of Philosophy \\ in \\ Economics \\ Joshua C. Hall, Ph.D. \\ Arabinda Basistha, Ph.D. \\ Maryam Naghsh, Ph.D. \\ Shuichiro Nishioka, Ph.D., Chair \\ Department of Economics \\ Morgantown, West Virginia \\ 2017
}

Keywords: Technology diffusion, Foreign education, TFP, Institutions and growth, International travel, Visa restrictions

Copyright 2017 Imran Arif 


\begin{abstract}
Three Essays on International Mobility and Economic Development
\end{abstract}

\author{
Imran Arif
}

This dissertation contains research on three topics in economic development. The main argument of this dissertation is that when societies interact they learn new ideas, superior technologies, and new production processes from each other. Any barriers to this interaction can hurt the diffusion of ideas across nations. Chapter 1 features a neglected channel of institution convergence among countries, i.e., international travel. International travel clearly increases human interaction over space and exposes societies to foreign influences, foreign ideas, and foreign institutions. Does international travel promote institutional change in a traveler's home country? This paper uses panel data on 149 countries from 1995-2012 to test the hypothesis of institutional convergence among countries stemming from international travel. Our instrumental variable results indicate that institutions are very persistent over time and that international travel itself is not a significant determinant of institution quality in the home country. However, institutional quality in host countries visited by travelers has a significant effect on home country institutions, and this effect increases with the number of travelers. In the system GMM settings, we do find evidence for institutional convergence among countries. Chapter 2 investigates whether foreign qualified students bring new ideas and technical expertise from abroad, disperse them, and stimulate aggregate productivity in their home countries. An instrumental variable is derived from a fitted gravity equation model. An unbalanced panel data of 111 countries during the period 1950-2012 shows that foreign education has a statistically significant effect on technology diffusion. The results are robust across different sub-samples and to the inclusion of other channels of technology diffusion. These findings should prove helpful to policy makers in developing economies to adopt more open education policies and to increase public spending on foreign education. Chapter 3 tests the relationship between barriers to international mobility and technology diffusion. Barriers to international mobility are the critical factors to impede the process of international technology diffusion. Using bilateral visa restrictions data from 30 host and 198 home countries over the period of 2001-2012, this paper shows that the international technology gap increases as the barriers to international mobility increase. These results are robust across three different measures of visa restrictions and even after taking care of econometric problem of endogeneity. The results suggest that visa facilitation programs by advanced countries could promote international technology diffusion. 


\section{Acknowledgements}

I would like to thank my dissertation committee of Dr. Shuichiro Nishioka, Dr. Joshua C. Hall, Dr. Arabinda Basistha, and Dr. Maryam Naghsh for all the support and guidance in this process. I would like to express the deepest appreciation to my committee chair Dr. Shuichiro Nishioka, who spent countless hours meeting with me to improve the quality of my research. Without his guidance and persistent help this dissertation would not have been possible. I am also very grateful to Dr. Joshua C. Hall who has been a great coauthor and mentor. His help on my dissertation is invaluable. I would also like to thank other graduate students in my cohort, particularly Danko Tarabar, and Zachary McGurk, who have been a constant source of support and guidance. I especially thank Dr. Antonio Spilimbergo and the World Tourism Organization staff for sharing their data. This research would not have possible without these two databases. 


\section{Contents}

Acknowledgements $\quad$ iii

List of Figures $\quad$ vii

List of Tables $\quad$ viii

$1 \quad$ International Flows of People and Institutional Convergence $\quad 1$

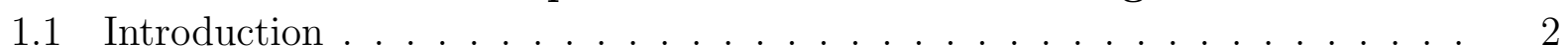

1.2 How does International Travel Affect Institutions? . . . . . . . . . . . . . . . 5

1.3 Trends in International Travel . . . . . . . . . . . . . . . . . . . . . . . . . . 7

1.4 Empirical Analysis . . . . . . . . . . . . . . . . . . . . . . . . . . . . . . . . . . . . . . . . . .

1.4 .1 Data . . . . . . . . . . . . . . . . . . . . . . . . . . . . . . . . . . . . . . .

1.4 .2 Baseline Specification . . . . . . . . . . . . . . . . . . . . . . . . . . . . . . . .

$1.4 .3 \quad$ A First Look at the Relationship . . . . . . . . . . . . . . . . . . . . 12

1.4 .4 Instrument Construction . . . . . . . . . . . . . . . . . . . . . . . 13

$1.4 .5 \quad$ Instrument Validity . . . . . . . . . . . . . . . . . . . . . . . . . . . . . 14

$1.4 .6 \quad$ Bilateral Travel Gravity Equation Estimation . . . . . . . . . . . . . . 15

1.4 .7 Instrumental Variable Estimation . . . . . . . . . . . . . . . . . . 16

1.4 .8 Alternative Dependent Variables . . . . . . . . . . . . . . . . . . 17

1.4 .9 Institutional Convergence and System GMM . . . . . . . . . . . . . . 18

1.5 Conclusion . . . . . . . . . . . . . . . . . . . . . . . . . . . 19

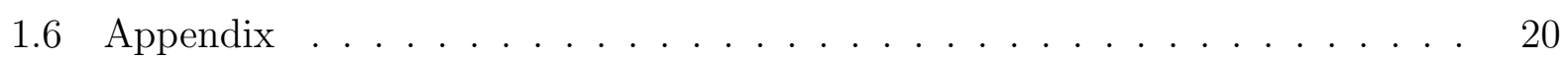

2 Foreign Education, Technology Diffusion, and Productivity 38

2.1 Introduction $\ldots \ldots \ldots \ldots \ldots \ldots \ldots$

$2.2 \quad$ How Does Foreign Education Help Technology Diffusion? . . . . . . . . . . . 41

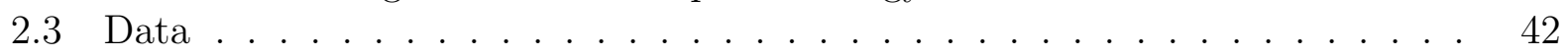

2.4 Empirical Methodology . . . . . . . . . . . . . . . . . . . . . . . . . . . . . . . . . . . . . . . . . . . . 43

2.4 .1 Partial Correlations . . . . . . . . . . . . . . . . . . . . . 43

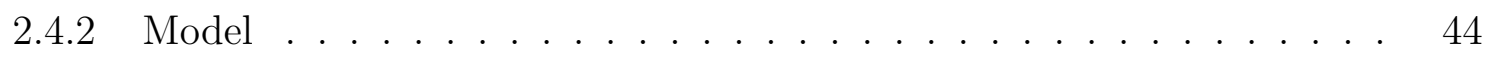

2.4 .3 Bilateral Equation Estimation . . . . . . . . . . . . . . . . . . . . . . . . . 44

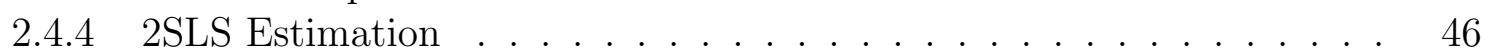

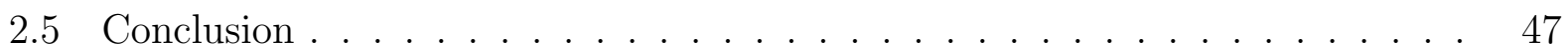

2.6 Appendix $\ldots \ldots \ldots \ldots \ldots \ldots$ 
$3 \quad$ Barriers to International Mobility and Technology Diffusion 59

$3.1 \quad$ Introduction $\ldots \ldots \ldots \ldots \ldots \ldots \ldots$

3.2 How Do Barriers to Mobility Affect International Technology Diffusion? . . . 63

3.3 Trends in International Travel and Barriers to Mobility . . . . . . . . . . . . 66

3.4 A Brief History of Barriers to Mobility . . . . . . . . . . . . . . . . . . . 67

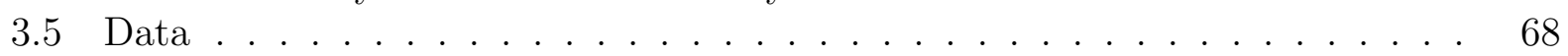

3.6 Empirical Analysis . . . . . . . . . . . . . . . . . . . . . . . . . . . . . . . . . . . . . . . . . .

3.6 .1 Partial Correlations . . . . . . . . . . . . . . . . . . . . . . 70

3.6 .2 Specification . . . . . . . . . . . . . . . . . . . . . . . . . . . . . . . . . . . . . . . . . . .

3.6 .3 OLS Estimation . . . . . . . . . . . . . . . . . . . . . . . . . . . . . . . . . . . . . . . . . . . . . . . . 72

3.6 .4 IV Estimation . . . . . . . . . . . . . . . . . . . . . . . . . . . . . . . . . . . . . . . . . .

3.6 .5 Logit Model Estimation . . . . . . . . . . . . . . . . . 76

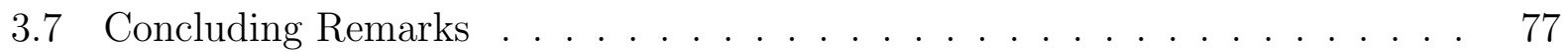

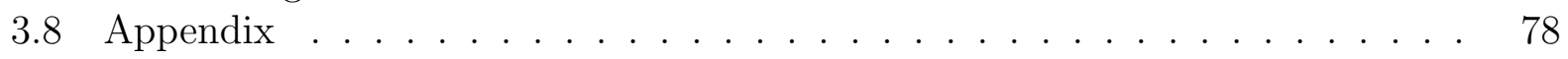




\section{List of Figures}

1.1 Total Number of International Travelers (million) . . . . . . . . . . . . . . . . 20

1.2 International Travel (annual percentage change) . . . . . . . . . . . . . . . . 21

1.3 Top Ten Destination Countries for International Travel (in 2012) . . . . . . . 22

1.4 Top Ten Origin Countries for International Travel (in 2012) $\ldots . . . . . . . .23$

1.5 International Travel (Region-wise) $\ldots \ldots \ldots \ldots$. . . . . . . . . . . . . 24

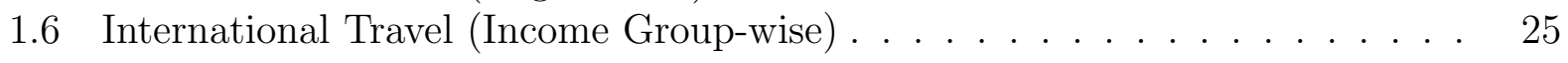

2.1 Total Number of International Tertiary Level Students . . . . . . . . . . . . 49

2.2 Top Ten Origin Countries for International Students (thousands) . . . . . . . 50

2.3 Top Ten Destination Countries for International Students . . . . . . . . . . . 51

$3.1 \quad$ Relationship between Visa Refusal Rate and TFP Gap . . . . . . . . . . . . 79

3.2 Most Restricted Countries of the World . . . . . . . . . . . . . . . . . . . . . 80

3.3 South Africa . . . . . . . . . . . . . . . . . . . . . . . . . . . . . . . . . 81 


\section{List of Tables}

1.1 Descriptive Statistics $\ldots \ldots \ldots \ldots \ldots$

1.2 Dependent Variable: Polity IV Index (OLS) . . . . . . . . . . . . . . . . . . . . 27

1.3 Bilateral Travel Gravity Equation . . . . . . . . . . . . . . . . . . . . . . . 28

1.4 Dependent Variable: Polity IV Index (2SLS) . . . . . . . . . . . . . . . . . . . . . 29

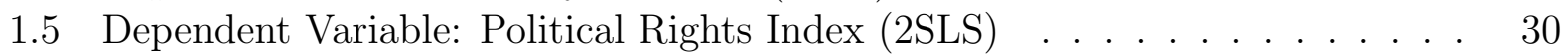

1.6 Dependent Variable: Civil Liberties Index (2SLS) . . . . . . . . . . . . . . . . . . . . 31

1.7 Institutional Convergence (System GMM) $\quad \ldots \ldots \ldots \ldots$

1.8 Correlation Matrix $\ldots \ldots \ldots \ldots$. . . . . . . . . . . . . . . . . . . . . . . . . . . 33

1.9 Region-wise Travel Patterns (in million) . . . . . . . . . . . . . . . . . . . . 34

1.10 Region-wise Travel Patterns (percentage share) . . . . . . . . . . . . . . . . 35

1.11 Travel Patterns (Income Group-wise) . . . . . . . . . . . . . . . . . . . . . . . . . . 36

1.12 List of Countries in the Sample . . . . . . . . . . . . . . . . . . 37

$2.1 \quad$ Descriptive Statistics $\ldots \ldots \ldots \ldots$. . . . . . . . . . . . . . . . . . . . 52

2.2 Correlation Matrix . . . . . . . . . . . . . . . . . . . . . . . . . . 53

2.3 Bilateral Foreign Education Equation . . . . . . . . . . . . . . . . . . . . . . 54

2.4 Dependent Variable: $\ln (\mathrm{TFP}) \quad \ldots \ldots \ldots$. . . . . . . . . . . . . . . . 55

2.5 Medium Run and Long Run (Pooled 2SLS) . . . . . . . . . . . . . . . . . . . . 56

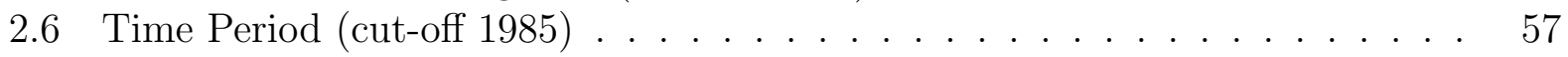

2.7 List of Countries in the Sample . . . . . . . . . . . . . . . . . . . . . 58

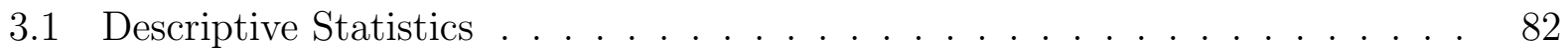

3.2 Correlation Matrix . . . . . . . . . . . . . . . . . . . . . . . . . . 83

$3.3 \quad$ Dependent Variable: Bilateral TFP Gap (percent) . . . . . . . . . . . . . . . . . 84

3.4 Dependent Variable: Bilateral TFP Gap (percent) . . . . . . . . . . . . . . . . 85

3.5 Correlation between Endogenous Variables . . . . . . . . . . . . . . . . . . . 86

$3.6 \quad$ Dependent Variable: $\ln$ (Visa Refusal Rate) $\ldots \ldots$. . . . . . . . . . . . . . . . 86

3.7 IV Estimation . . . . . . . . . . . . . . . . . . . . . . . . . . . . . . . . . 87

3.8 Dependent Variable: Does TFP Gap between Country $i$ and Country $j$ Exist?

$(\mathrm{Yes}=1, \mathrm{No}=0) \ldots \ldots \ldots \ldots 8 \ldots \ldots$

A1 Country-wise Average Visa Refusal Rates (2001-2012) . . . . . . . . . . . . . 89

A2 $\quad$ World Passport Ranking . . . . . . . . . . . . . . . . . . . . . . . . . 90

A3 List of Host Countries in the Sample . . . . . . . . . . . . . . . . . . . . . . 91

A4 $\quad$ List of Origin Countries in the Sample . . . . . . . . . . . . . . . . . . . . . 92 


\section{Chapter 1}

\section{International Flows of People and Institutional Convergence}

This paper features a neglected channel of institution convergence among countries, i.e., international travel. International travel clearly increases human interaction over space and exposes societies to foreign influences, foreign ideas, and foreign institutions. Does international travel promote institutional change in a traveler's home country? This paper uses panel data on 149 countries from 1995-2012 to test the hypothesis of institutional convergence among countries stemming from international travel. Our instrumental variable results indicate that institutions are very persistent over time and that international travel itself is not a significant determinant of institution quality in the home country. However, institutional quality in host countries visited by travelers has a significant effect on home country institutions, and this effect increases with the number of travelers. In the system GMM settings, we do find evidence for institutional convergence among countries. 


\section{$1.1 \quad$ Introduction}

People travel abroad for a variety of reasons: vacation, business, academic, religious work, performing athletic or artistic work, medical treatment, etc. These travelers are exposed to foreign influences, foreign ideas, and foreign institutions. Does this exposure help them improve institutions in their home countries? In order to explore the statistical relationship between institutions and temporary cross border travel, this study follows Spilimbergo (2009), Glaeser et al. (2007), Acemoglu et al. (2005), La Porta et al. (1999), and Barro (1999) and features an institution quality index as a dependent variable. The baseline specification follows Spilimbergo (2009) and includes three explanatory variables: international travel as a share of population, average institutions in host countries, and an interaction term between the two. The average institutions in host countries variable captures the idea that travelers experience different types of institutions in different countries, and hence bring back different institutional knowledge from abroad. For example, an international traveler experiences different type of institutions in Saudi Arabia than in the U.S. The interaction term shows whether the marginal effect of international travel depends on the institutions in the host countries. We use the well-known Polity IV index as a primary dependent variable, and test the robustness of the results by using two additional measures of political institutions: a political rights index and a civil liberties index. $]^{1}$

International travel is likely to be endogenous in the model. Countries with better quality institutions may show more travel intensity due to reasons unrelated to institutions. To deal with this endogeneity, we construct an instrument for international travel by estimating a bilateral travel gravity equation containing bilateral geographic factors. These geographic factors are distinct from those effecting institutions directly $\left.\right|^{2}$ The estimated values of the bilateral travel equation are then summed up to calculate aggregate predicted travel values, and used as an instrument for the international travel. In using a bilateral travel equation as an instrument for the international flows of people, we are following the work of Andersen and Dalgaard (2011) and Spilimbergo (2009).

\footnotetext{
${ }^{1}$ Polity IV is a widely used measure of political institutions in cross-country literature. See, for example, Leeson (2008), Leeson and Dean (2009), Sobel and Coyne (2011), and Dutta et al. (2013).

${ }^{2}$ We further discuss the validity of these instruments in section 1.4.5.
} 
We use an annual unbalanced panel of 149 countries from 1995-2012 to estimate the relationship between institutions and international travel. Our two-stage least squares estimates show that (1) institutions are very persistent over time, (2) there is no direct evidence that international travel, as a share of population, is a significant determinant of institution quality in the country of origin, (3) institutions in the host countries have a significant effect on home country institutions, and (4) the marginal effect of average institutions in host countries is positive and increases with the number of travelers. The results are almost consistent across three measures of political institutions: the Polity IV index, the political rights index, and the civil liberties index. These results show that there is little support of institutional convergence among countries via international flows of people. Although, our results in the system GMM settings are not consistent with OLS and two-stage least squares, but we do find evidence for institutional convergence among countries.

Our paper adds to the literature in that we explore the effects of international flows of people on home country institutions. Earlier research primarily focuses on the impact of emigration on development and democracy in the country of origin. Spilimbergo (2009) is an exception as he analyzes the effects of foreign educated individuals on the level of democracy in the home country. However, Spilimbergo (2009) focuses on a specific group of cross-border travelers, tertiary level international students. Here we are able to look at all international travelers who stayed in another country for less than a year.

We expect our results to further expand upon the insights of Spilimbergo (2009) for four reasons. First, most people travel to other countries for non-academic reasons. We might, therefore, expect that non-academic international travelers might have a larger effect on their home country institutions given that they comprise a larger share of the home country population. Second, the majority of international students belong to the elite of their country (Spilimbergo, 2009). These students may be more interested in the status quo in their home countries. This may be due to the political and economic rents that the elite accrue from the status quo (Acemoglu and Robinson, 2000). Ordinary citizens, on the other hand, can directly gain from changing the political system in the home country. Third, students, while their time in the host country, spend most of their time on-campus and they may be too busy studying and have a little time to take interest in host country politics. Ordinary citizens, 
however, travel to other countries for personal and business reasons and are likely to have more direct interaction or discussion regarding host country political institutions. Fourth, and perhaps most pragmatic, is the element of time. The data set on international tertiary level students contains students who cross national borders to study outside their country of citizenship for more than a year, while our international travel data set contains data for international travelers who stayed in another country for less than a year.

In addition to the literature on student flows, our paper relates to two other important topics in the institutional literature. First, our paper clearly relates to the literature exploring the relationship between migration and home country institutions. For example, Dos Santos and Postel-Vinay (2003) and Dustmann et al. (2011) find that migrants accumulate knowledge in foreign countries, and return migrants use this knowledge for economic expansion in the home country. Docquier and Rapoport (2012), Beine et al. (2001), and Mountford (1997) explore the effects of brain drain in the home country. Li et al. (2016) analyze the impact of migration on both economic and political institutions. They argue that migration has a direct effect on the human capital and thus on institutional development in the home country. Their findings suggest that brain drain has a positive effect on political institutions and a negative effect on economic institutions. Docquier et al. (2010) split migration data into two parts: skilled and unskilled migrants. They find that both openness to migration and human capital has a positive effect on institutions in the home country, unskilled migration improves institutional quality, and brain drain has an ambiguous effect. Second, our work relates to a smaller, emerging literature on institutional convergence (Elert and Halvarsson, 2012; Heckelman and Young, 2014; Hall, 2016).

We organize our paper as follows: section 1.2 explores how does international travel affect institutions, section 1.3 presents trends in international travel, section 1.4 describes our empirical strategy, a description of our data, and regression results, and section 1.5 concludes. 


\subsection{How does International Travel Affect Institutions?}

So, how does international travel affect institutions in the home country? Before turning to the channels through which international travel may affect institutions, it is worthwhile to define institutions, why they are important, how they emerge, and then relate international travel with institutions. North (1990) states that, "institutions are the rules of the game in a society or, more formally, are the humanly devised constraints that shape human interaction," and refers to them as critical determinants of economic development. Similarly, Acemoglu et al. (2002) and Acemoglu and Johnson (2005) argue that institutions shape the society and provide a framework for economic growth by reducing uncertainty.

Better quality institutions comprise of well-defined property rights and the rule of law. Economic activity flourishes in the environment of better quality institutions, people have an incentive to invest in physical capital, human capital, technology, and innovation Glaeser et al., 2004). Who would invest in a country without the rule of law and without a political and judicial system that respects property rights? A political system that ensures property rights performs better than a system with a high probability of expropriation. Given this, institutions are considered a necessary condition for economic growth Knack and Keefer, 1995; Acemoglu et al., 2002; Acemoglu and Johnson, 2005).

Why do different institutions emerge in different countries and how does international travel affect them? There are four popular views about the emergence of different institutions in different countries: the efficient institution view, social conflict theory, the incidental view, and the ideology view. According to the efficient institutions view, societies choose the type of institutions that maximize their total surplus. Demsetz (1967) argues that societies enforce property rights when the benefits of enforcing exceed the costs. Some societies may choose not to enforce property rights because the net benefits are less than the costs.

Frankel and Romer (1999) argue that international human interaction increases international trade. Andersen and Dalgaard (2011) and Tani and Joyeux (2013) argue that international travel increases productivity and technology diffusion in the home country. This implies that international travel increases the total wealth of a country. An increase in wealth increases the benefits of enforcing property rights relative to the costs, because (1) 
there is more wealth to protect from other individuals and the state and (2) the society can better afford to enforce property rights. The notion that as societies become richer they can afford to enforce property rights can be traced to North (1990) and Przeworski (2005).

According to social conflict theory, institutions emerge not as a choice by the whole society, but by the groups holding the political power at that time. These groups choose institutions which increase their own economic rents instead of maximizing the total surplus of the whole society. International human interaction not only increases the income of the home country, as stated above, but also exposes travelers to alternative institutions in other countries. As a result of an increase in wealth, individuals gain more de facto political power, which often results in an increase in the demand for better institutions. For example, Batista and Vicente (2011) find evidence that migrants learn governance and accountability in the host country, which helps to improve governance and accountability in their home countries. International travelers may also increase the demand for better quality institutions in their home countries. International travelers are in a better position to raise their voice, because they have an option to leave their country and have access to the international community and foreign media.

International travel has played a major role in developing and shaping the political philosophies of many leaders. For example, Gandhi developed most of his political ideas and leadership skills in South Africa (Power, 1969). According to some authors, even a small minority can change the fate of the whole country. For example, Jones et al. (2005) find evidence in favor of individual leaders having an effect on the economic development of a country. Similarly, Spilimbergo (2009) argues that foreign educated leaders can change the institutional structure of a country.

The ideology view of institutions suggests that societies may have different institutions because they have different ideologies and beliefs. International travel may expose societies to new ideologies and beliefs. Greater interaction with foreign ideologies and beliefs may change the ideologies and beliefs of the home country. $]^{3}$ This change may provide roots to reform the political institutions in the home country. Sheehan and Young (2015) find

\footnotetext{
${ }^{3}$ One recent unfortunate example of traveling and a change in belief is the Boston Marathon bombing (2012) perpetrator, Tamerlan Tsarnaev, who was radicalized while traveling to Russia.
} 
that greater interaction via the Internet increases institution quality. Similarly, Bergh et al. (2014) finds that globalization has positive effects on institution quality.

While the previous three views of institutions argue that societies or some groups choose institutions in a country, the incidental view of institutions suggests that institutions are the by-product of other social interactions. For example, La Porta et al. (1999), Acemoglu et al. (2002), and Acemoglu and Johnson (2005) argue that institutions today depend on the colonial history of a country. Many countries, today, have the same type of institutions as their ex-colonizers. For example, the countries colonized by the British have a commonlaw tradition and those colonized by the Spanish, such as Latin American countries, have a civil-law tradition. La Porta et al. (1998) find that common-law, relative to French-law and other law systems, is the best at protecting property rights. Similarly, Acemoglu and Cantoni (2011) argue about the institutional reforms in Europe brought about by the French Revolution and by Napoleon. While our paper cannot directly distinguish across these channels, our results provide an important mechanism through which institutions evolve.

\subsection{Trends in International Travel}

International travel data show a strong increasing trend from 1995-2012 and is expected to increase by 3.3 percent a year from 2010 to 2030 (World Tourism Organization, 2014). About 1.60 billion people crossed international borders in 2012 compared to 0.85 billion in 1995. This shows an increase of 86 percent in the total number of international travelers from 1995 to 2012. Figure 1.1 in the appendix shows a snap shot of the total number of international travelers over the period 1995-2012. This figure shows an upward trend in the number of international travelers; more people are crossing international borders today than ever before.

Figure 1.2 represents the annual growth rate of international travel during 1995-2012. The average annual growth rate of international travel is about 4.0 percent during 19952012. Most of the years show a steady and positive growth in international travel. This figure shows the highest growth rate of 10.3 percent in 2004 and the lowest growth rate of -3.9 in 2009 (post-Great Recession). Figure 1.3 shows the top ten destination countries for 
international travelers. In 2012, France was the top destination country for international travelers and hosted about 83 million visitors. France is followed by the U.S. and China, each hosted 67 million and 57 million visitors, respectively. Other countries in this list include Spain, Italy, Turkey, Germany, the U.K., Russia, and Malaysia. Figure 1.4 shows top ten origin countries for international travel. This list includes the U.S. (27.6 million), Germany (20 million), France (11.1 million), the UK (10.4 million), Russia (6.7 million), Austria (4.9 million), China (4.8 million), Malaysia (4.4 million), Switzerland (4.3 million), and the Netherlands (4.2 million).

International travel data also reveals that international mobility depends on the location and income group of the home country. Figure 1.5 (see, also Table 1.9, and Table 1.10) shows the regional distribution of international travelers during the period 1995-2012. In 2012, about 890 million travelers originated from Europe and Central Asia, 342 million from East Asia and Pacific, 172 million from North America, 62 million from Latin America and Caribbean, 63 million from the Middle East and North Africa, and about 24 million from both South Asia and Sub-Saharan Africa. From 1995 to 2012, the travel share of Europe and Central Asia decreased from 61 percent in 1995 to 56 percent in 2012 while the share of East Asia and Pacific increased from 15 percent to 22 percent, the Middle East and North Africa increased from 2.13 percent to 4 percent, Latin America and the Caribbean increased from 3.23 percent to about 4 percent, South Asia increased from 0.87 percent to 1.57 percent, and for Sub-Saharan Africa increased from 1.33 percent to 1.52 percent. ${ }^{4}$ Overall, during 18 years of sample period, about 59 percent of international travelers originated from Europe and Central Asia, 18 percent from East Asia and Pacific, 13.3 from North America, 3.50 percent from Latin America and Caribbean, 3.35 percent from Middle East and North Africa, 1.60 percent from Sub-Saharan Africa, and 1.20 percent from South Asia.

The distribution of international travel based on the income level of the home country also shows the same dispersion. Figure 1.6 shows the distribution of international travel based on the income level of the home country!5 In 1995, high income countries had the largest share in international travel (about 90 percent), followed by upper middle income countries

\footnotetext{
${ }^{4}$ Table 1.10 shows the travel share of each region.

${ }^{5}$ Income group classifications are taken from WDI. The data for Figure 1.6 can be found in Table 1.11.
} 
(6.54 percent), lower middle income countries (3.16 percent), and low income countries (0.56 percent). From 1995 to 2012, the travel share decreased from 90 percent to 79 percent for high income countries, increased from 6.54 percent to 14 percent for upper income countries, increased from 3.16 percent to 6.30 percent for lower middle income countries, and increased from 0.56 percent to 0.96 percent for low income countries. Travel share, during 18 years of sample period, shows the same pattern. About 84.74 percent of international travelers originated from high income countries, 9.59 percent from upper middle income countries, 4.84 percent from lower middle income countries, and 0.82 percent from low income countries. This shows that citizens from some regions and high income group have an advantage in international mobility, and they are more exposed to foreign influences, ideas and institutions.

\subsection{Empirical Analysis}

\subsubsection{Data}

This paper uses an annual unbalanced panel of 149 countries from 1995-2012 to estimate the relationship between institutions and international travel. This section briefly describes our variables and data sources.

Travel: This variable shows the number of international outbound travelers as a share of population from the home country and is denoted by Travel. The data for this variable are taken from the UN World Tourism Organization (UNWTO). UNWTO reports the annual number of arriving and departing travelers who stayed in another country for less than a year for business, leisure, and any other purpose. UNWTO reports the data of international travelers in 12 different categories. The data series begins with 1995 and we construct the variable Travel as the mean value across these 12 categories.

Polity IV Index: Polity IV is our primary measure of political institutions. Some economists believe that the Polity index, compared to other measures of institutions, is a better measure of institution quality. The argument is that it shows the constraint on the executive while other measures of institutions are policy outcomes (Glaeser et al., 2004). The Polity IV dataset covers all major and independent states over the period 1800-2012 
and reports polity scores on a scale ranging from -10 to 10, where 10 indicates a consolidated democracy and -10 indicates an autocracy. Our paper, similar to other studies such as Spilimbergo (2009) and Barro (1999), normalizes this index on a scale ranging from 0 to 1 for an easier interpretation, where 0 indicates low institution quality and 1 indicates high quality institutions.

Political Rights Index: Political rights index shows the extent to which citizens of a country enjoy free and fair elections, opposition parties are competitive and enjoy real power, and minority groups have representation in the country. The data for this index are taken from Freedom House. Freedom House reports this index on a scale ranging from 1 to 7, with 1 indicating a wide range of political rights and 7 indicating a few or no political rights. In our analysis, we normalized this variable on a scale ranging from 0 to 1 , where 0 indicates no political rights and 1 indicates a wide range of political rights.

Civil Liberties Index: Civil liberties index shows the extent to which citizens of a country enjoy freedom of expression, assembly, association, education, religion, a fair legal system to ensure rule of law, free economic activity, and equal opportunities for everyone. This index is also reported by Freedom House on a scale ranging from 1 to 7 , with 1 indicating a wide range of civil liberties and 7 indicating a few or no civil liberties. This index is also normalized on a scale ranging from 0 to 1 , where 0 indicates no civil liberties and 1 indicates a wide range of civil liberties.

Institutions in Host Countries: Institutions in host countries variable shows the type of institutions travelers experience while traveling abroad. This variable is constructed as the weighted average of institutions in host countries, where weights are given as the share of total travelers to that host country over total international travelers from the home country. The value of this index lies between 0 and 1 , where 1 indicates that all international travelers from the home country went to host countries with better quality institutions, and 0 indicates that all international travelers from the home country went to host countries with low quality political institutions. Average institutional quality in the host countries is calculated as

$$
\text { Average institutions in host countries }=\sum_{i} \frac{\text { Travel }_{i j, t}}{\sum_{i} \text { Travel }_{i j, t}} \text { host }_{\text {institution }}, t
$$


Students: This variable shows the number of tertiary level international students (university education and higher) as a share of population, and is denoted by Students. This variable refers to students who cross national border to study outside their country of citizenship, or are enrolled in a distance learning program abroad for more than a year. The data for this variable are taken from UNESCO.

Other Control Variables: We also include Infant Mortality Rate- the number of infants dying before reaching one year of age per 1,000 live births in a given yearLife Expectancy at Birth - the average number of years a newborn infant would liveUrbanization Rate - the annual percentage growth rate of population living in the urban areas - GDP per capita, Primary Education, and Population. The data for these variables are taken from WDI. Data for geographic factors are taken from the well-known CEPII database.

\subsubsection{Baseline Specification}

To test the statistical relationship between institution quality and the international flows of people, this paper follows Spilimbergo (2009), Glaeser et al. (2007), Acemoglu et al. (2005), La Porta et al. (1999), and Barro (1999) and uses an index of institution quality as a dependent variable. The baseline specification follows Spilimbergo (2009) and estimates the following regression equation

$$
\begin{aligned}
\text { Inst }_{i, t}=\beta_{0} \text { Inst }_{i, t-5} & +\beta_{1} \ln \left(\text { Travel }_{i, t-5}\right)+\beta_{2} \text { Inst. }_{\text {in host countries }} \text { crt }-5 \\
& +\beta_{3} \ln \left(\text { Travel }_{i, t-5}\right){ }^{*} \text { Inst. in host countries } \text { Irt }_{i, 5} \\
& +\beta_{4} X_{i, t-5}+\epsilon_{i, t}
\end{aligned}
$$

where Inst $_{i, t}$ is the index of institution quality at time $t$ in country $i$. Although the primary dependent variable of this paper is the Polity IV index, this paper checks the robustness of the regression results by using two additional dependent variables: the civil liberties index and the political rights index. Other explanatory variables are $\ln \left(\right.$ Travel $\left._{t-5}\right)$; the total number of outbound travelers as a share of population, Inst. in host countries ${ }_{i, t-5}$; the type of institutions travelers experience in the host country, and the interaction term between the two variables. 
Variable Inst. in host countries ${ }_{i, t-5}$ shows the average institution quality in the host countries. This variable is constructed as the weighted average of institutions in the host countries where weights are given as the share of total travelers to that host country over all international travelers from the home country.6 This index lies between 0 and 1, where 1 indicates that all international travelers went to the host countries with better quality institutions, and 0 indicates that all international travelers went to the host countries with weak institutions. The interaction term between Travel and Inst. in host countries captures whether the marginal effect of international travel depends on the institutions in the host countries. $X_{i, t-5}$ is a vector of control variables ${ }^{7}$ and contains the number of tertiary level international students (university education and higher) as a share of population, GDP per capita, primary education, urbanization rate, the infant mortality rate, and life expectancy at birth. All control variables are lagged five years. Finally, $\epsilon_{i, t}$ captures the omitted variables and noise.

\subsubsection{A First Look at the Relationship}

The correlation coefficient value between Travel and Polity $I V$ is about 0.62 , which is relatively high. The correlation coefficient for Polity in Host Countries, evaluated at total number of travelers is 0.61 . These numbers show that a basic relationship between international travel and institutions does exist 8

As a next step to show the correlation between the independent variables and institutions, table 1.2 columns (1)-(3) represent the ordinary least squares estimates for the dependent variable Polity IV. Column (1) shows our baseline specification, with Travel, Polity, Average Polity in Host Countries, and Average Polity in Host Countries * Travel included. All variables are lagged five years to reflect the fact that institutions change slowly. Columns (2) and (3) show the robustness of our baseline results to the inclusion of additional control variables. These specifications explains roughly 0.80 percent of the variation in the dependent variable. The high $\mathrm{R}$-squared value reflects the presence of the lagged dependent variable

\footnotetext{
${ }^{6}$ The data section for more detail on the construction of all variables.

${ }^{7}$ All control variables are adopted from Barro (1999)

${ }^{8}$ Appendix table 1.8 reports partial correlations between institutions and all other explanatory variables.
} 
on the right hand side.

The five-year lagged dependent variable, Polity $I V_{i t-5}$, shows a strong statistical significance and a coefficient value of 0.488 . This indicates that institutions are persistent over time. Variable Travel is statistically significant and has a negative coefficient value of 0.03. This shows that international travel is negatively related to home country institutions once the effect of institutions in host countries is taken into account.$^{9}$ Polity in Host Countries it-5 is positive and statistically significant. This indicates that the effects of international travel on home country institutions depend on the type of institutions in the host countries. The interaction term, showing the marginal effect of travel, has positive and statistically significant value. This reflect that the marginal effect of institutions in the host countries increases with the number of travelers.

\subsubsection{Instrument Construction}

The travel variable is likely to be endogenous in equation 1.2 , as countries with better institutions may experience higher travel intensity due to reasons unrelated to institution quality. Ordinary least squares estimates would be biased and inconsistent in this case. We deal with this endogeneity by constructing an instrumental variable for international travel. This instrument is constructed by using a travel bilateral gravity equation 10 We follow Andersen and Dalgaard (2011) and estimate a travel bilateral gravity equation using different geographic factors.

$$
\text { Travel }_{i j, t}=a^{\prime} Z_{i j, t}+\delta_{i j, t}
$$

where Travel $_{i j, t}$ indicates the number of outbound travelers, as a share of population, from the home country $i$ to the host country $j$ at time $t, Z_{i j, t}$ is a set of regressors used by Andersen and Dalgaard (2011) and Frankel and Romer (1999) and includes the distance between the home country and the host country, population of the home country, population of the host country, area of the home country, area of the host country, and dummy variables indicating 1 if the home country is landlocked and 0 otherwise, 1 if the host country is landlocked and

\footnotetext{
${ }^{9}$ Travel $_{i t-5}$ is positively related to institutions when not interacted with Polity in Host Countries $i t-5$.

${ }^{10}$ Andersen and Dalgaard (2011) and Frankel and Romer (1999) motivate our choice of explanatory variables in the gravity equation.
} 
0 otherwise, and 1 if a country pair shares a border and 0 otherwise $\left(\right.$ Contiguity $\left._{i, j}\right)$. The above regression equation also contains interaction terms between Contiguity $_{i, j}$ and all other variables.

The predicted values of travel variable from Equation 1.3 are calculated, and then summed up to find the aggregate travel variable as follows.

$$
(\widehat{\text { Travel }})_{i t}=\sum_{j \neq i} e^{\widehat{a}^{\prime} Z_{i j, t}}
$$

The values of travel variable obtained from equation 1.4 are used to instrument international travel in the equation 1.2 .

\subsubsection{Instrument Validity}

We use geographic factors to instrument for Travel. Geography has been shown to influence institutions. Easterly and Levine (2003); Rodrik et al. (2004) argue that geography affected income through institutions. This would be problematic for our identification strategy if we were to use geographic factors associated with institutional quality to instrument for Travel. However, we avoid the geographic measures found to be associated with institutions, such as latitude, area in the tropics, settler mortality, malaria proportion, etc. Acemoglu and Robinson, 2001; Easterly and Levine, 2003; Rodrik et al., 2004). Instead, we employ geographic factors related to international travel but unrelated to institution quality.

We use the following geographic factors as instruments: distance between a country pair, population size of both countries, area of both countries, whether the countries have a sea shore, and whether the country pair shares a border. These geographic factors are different than those factors directly related to institutions. For example, distance between a country pair explains the flows of people between them but would have no direct effect on institutions in those countries. Countries located close to each other can have very different institutions, such as Austria and Serbia. Similarly, countries with a common border often have very different levels of institutional quality. Consider, for example, the United States and Mexico, or South Korea and North Korea.

The second set of instrumental variables, population size and area of both countries, determines the outflow and inflow of people, but does not affect institution quality in either 
country. We may expect high flows of people from large countries, but we may not expect large countries to have the same set of institutions (Canada vs. Russia). The final geographic variable, landlocked, does not define political institutions, but affects international flows of people. We may expect a high flows of people from countries with a seaport. This may reflect that countries with a seaport trade more with the rest of the world, and hence show more travel intensity.

\subsubsection{Bilateral Travel Gravity Equation Estimation}

As discussed previously, Travel is likely to be endogenous in the above model. People from countries with better quality institutions may travel more due to reasons unrelated with institutions. The Durbin-Wu-Hausman test confirms endogeneity in the model. To deal with this endogeneity an instrumental variable is needed. Andersen and Dalgaard (2011), based on the argument by Frankel and Romer (1999), use geographic factors to instrument for travel. We follow Andersen and Dalgaard (2011) and use the same instruments as Frankel and Romer (1999) to estimate a bilateral travel gravity equation. Bilateral travel flows $\ln \left(\right.$ Travel $\left._{i, j t}\right)$ is the dependent variable in this equation, and shows the number of international travelers from the home country $i$ to the host country $j$ at time $t$.

Table 1.3 provides OLS estimates for this bilateral travel gravity equation. This equation explains about 32 percent of the variation in the bilateral flows of people. International travel has a negative relationship with the distance between two countries. The elasticity of travel with respect to distance is -1.54 for countries not sharing a border. This elasticity drops to -1.24 if the country pair shares a border. This shows that as the distance between a country pair increases, fewer people travel between them. The intensity of travel between country $i$ and $j$ is decreasing with respect to the population size of the home country $i$, and increasing with respect to the population size of the host country, $j$. This shows that, small countries send, and large countries attract more international travelers. The intensity of travel between a country pair is decreasing with respect to the area of country $i$, and increasing with respect to the area of country $j$. The elasticity of travel with respect to home country area is -0.01 , if the country pair does not share a border, and -0.23 if the country pair shares a border. 
The elasticity of travel with respect to host country area is 0.25 if the country pair does not share a border, and increases to 0.42 if they share a border.

On average, landlocked countries send and attract fewer international travelers. This is shown by the negative and statistically significant coefficients for both variables Landlocked $_{i}$ and Landlocked $_{j}$. Variable Contiguity ${ }_{i, j}$ shows whether two countries share a border or not. The coefficient for this variable is statistically insignificant. This shows that, on average, countries sharing a border do not show a higher flows of people between them. To test the correlation between the fitted and the original values of variable travel, a simple OLS regression equation is estimated. The results show an R-squared of 0.88 , and the fitted values show a coefficient value of 0.8411

\subsubsection{Instrumental Variable Estimation}

Table 1.4 reports the Two-Stage Least Squares estimates for equation 1.2 where the aggregate predicted values of international travel are used as an instrument for the endogenous variable, Travel. The table repeats the specifications from equation 1.2 across the three columns. The explanatory power of model improves, with the 2SLS estimates now explaining $84 \%$ of the variation in a country's Polity IV measure. The five-year lagged dependent variable, Polity $I V_{i t-5}$, shows a statistically significant and economically large coefficient value of 0.846 in Column (3). This indicates that institutions are persistent over time. Travel $_{i t-5}$ has a statistically insignificant and negative coefficient value of -0.045 in Column (3), showing that international travel, stripped of its institutional context, is not a positive determinant of institutions in the home country. Our control variables, with the exception of

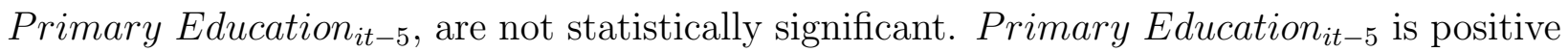
and statistically significant in both specifications in which it is included. This finding is consistent with Barro (1999) and indicates that a more educated society seems to be conducive to more democratic political institutions.

Average Polity in Host Countries ${ }_{t-5}$, our primary independent variables of interests, has a positive but statistically insignificant coefficient in Column (1) but is positive and

\footnotetext{
${ }^{11}$ Results not reported here but available upon request.
} 
statistically significant once additional controls are included in Columns (2) and (3). This indicates that the effects of international travel on home country institutions does appear to depend on the type of institutions in the host countries once we control for the endogeneity of Travel and other variables that help to explain political institutions, such as

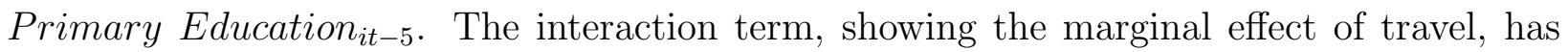
positive and statistically significant value in Columns (2) and (3), showing that the effect of travel through host countries institutions increases with the extent of travel.

\subsubsection{Alternative Dependent Variables}

To further test the robustness of regression results, we employ two additional measures of institutions as dependent variables: political rights index and civil liberties index. Table 1.5 shows regression results for political rights index from Freedom House as a dependent variable. Political rights score is based on the extent to which citizens of a country enjoy free and fair elections, competitive opposition, and representation of women and minority groups. We repeat the same three specifications from table 1.4 and find very similar results. Average PR in Host Countries ${ }_{i t-5}$ is positive and statistically significant across all three specifications. Average political rights in host countries have a positive effect on political rights in the home country and this effect increases with the number of travelers, as shown by the interaction term Average PR in Host Countries ${ }_{i t-5} * \ln \left(\right.$ Travel $\left._{i t-5}\right)$. This implies that international travel has a positive effect on the political rights in the home country only if the flows of people is towards the host countries with better political rights and this effect increases with the number of travelers.

Table 1.6 represents the TSLS regression results for civil liberties index as a dependent variable. This index shows the extent to which citizens of a country enjoy freedom of expression, assembly, association, education, religion, a fair legal system, free economic activity, and equal opportunities for everyone. Repeating our three primary specifications. The positive and statistically significant value on Civil Rights Index $x_{i t-5}$ in Columns (1)-(3) shows that civil liberties variable are very persistent over time. In terms of our primary variables of interest, Average CL in Host Countriesit - 5 is positive and statistically significantly 
related to civil liberties in a country. The interaction term with lagged travel is also positive and statistically significant. Combined these results are consistent with the view that average civil liberties in host countries have a positive effect on civil liberties in the home country and this effect increases with the number of travelers. This implies that international travel only influences civil liberties in the home country through citizen flows towards host countries with better civil liberties, and that this effects increases with the number of travelers.

\subsubsection{Institutional Convergence and System GMM}

There are two concerns estimating a model like equation 1.2 (1) country specific effects e.g. difference in taste or technologies (2) endogeneity of the explanatory variables. Taking advantage of our panel data, we were able to exploit methodology suggested by Caselli et al. (1996). Following Caselli et al. (1996) and Arellano and Bond (1991), we re-write the main regression equation 1.2 as a dynamic model in the level of institution quality. We then take the difference of the equation to eliminate any individual effects from the model. We then used the lagged variables of all the regressors to instrument for the endogenous variable.

The system GMM results are presented in table 1.7. Column 1-3 report the polity iv index, the political rights index, and the civil liberties index as dependent variables, respectively. The lagged dependent variable, Institution $s_{t-1}$, has a positive and statistically significant coefficient value in all three columns. This indicates that institutions are converging over time. A higher coefficient value implies that the rate of convergence is very slow. International travel has a statistically insignificant coefficient for the polity iv, political rights, and civil liberties. Average institutions in the host countries is statistically significant coefficient for political rights at 10 percent level of significance, and statistically insignificant for the polity iv and civil liberties. This shows that if travelers go to countries with better political rights, they will help improve political rights in their home countries. Although, our results in the system GMM settings are not consistent with OLS and twostage least squares, we do find evidence for institutional convergence among countries in the system GMM settings. 


\subsection{Conclusion}

Recent research shows that institutions are the key determinants of economic growth. Economic activity flourishes in the environment of good institutions, as people have an incentive to invest in physical and human capital. This paper adds to the existing literature by exploring whether institutions can transmit from one country to another country through human interaction. In that respect, this paper hypothesizes that as people travel abroad, they come into contact with foreign ideas, beliefs, and institutions. This exposure may help them to improve institutions in their home countries. Specifically, this paper analyzes whether international travel improve institution quality in the home country.

To test the relationship between international travel and institutions, this study uses UNWTO dyadic travel data and three measures of institutions: polity iv index, political rights index, and civil liberties index. International travel is likely to be endogenous in the model, as countries with better quality institutions may experience a high volume of international travel due to reasons unrelated with institutions. To deal with this endogeneity, an instrument variable is constructed by estimating a bilateral travel gravity equation, the predicted travel values are aggregated, and used as an instrument for international travel.

An unbalanced panel data of 149 countries during the period 1995-2012 in the TSLS settings reveal that institutions are very persistent over time. There is no direct evidence that international travel is a significant determinant of institutions in the home country. However, institution quality in the host countries has a positive effect on home country institutions and this effect increases with the number of international travelers. These results are, mostly, robust to the inclusion of other control variables and across three measures of institutions: polity iv index, political rights index, and civil liberties index. Although, our results in the system GMM settings are not consistent with OLS and two-stage least squares, but we do find evidence for institutional convergence among countries in the system GMM settings. An important policy suggestion from this study is to adopt an open foreign policy, to promote international good will, start soft visa programs with other countries to stimulate flows of people, so that the citizens of a country can learn from foreigners, and promote institutions in their home countries. 


\subsection{Appendix}

Figure 1.1: Total Number of International Travelers (million)

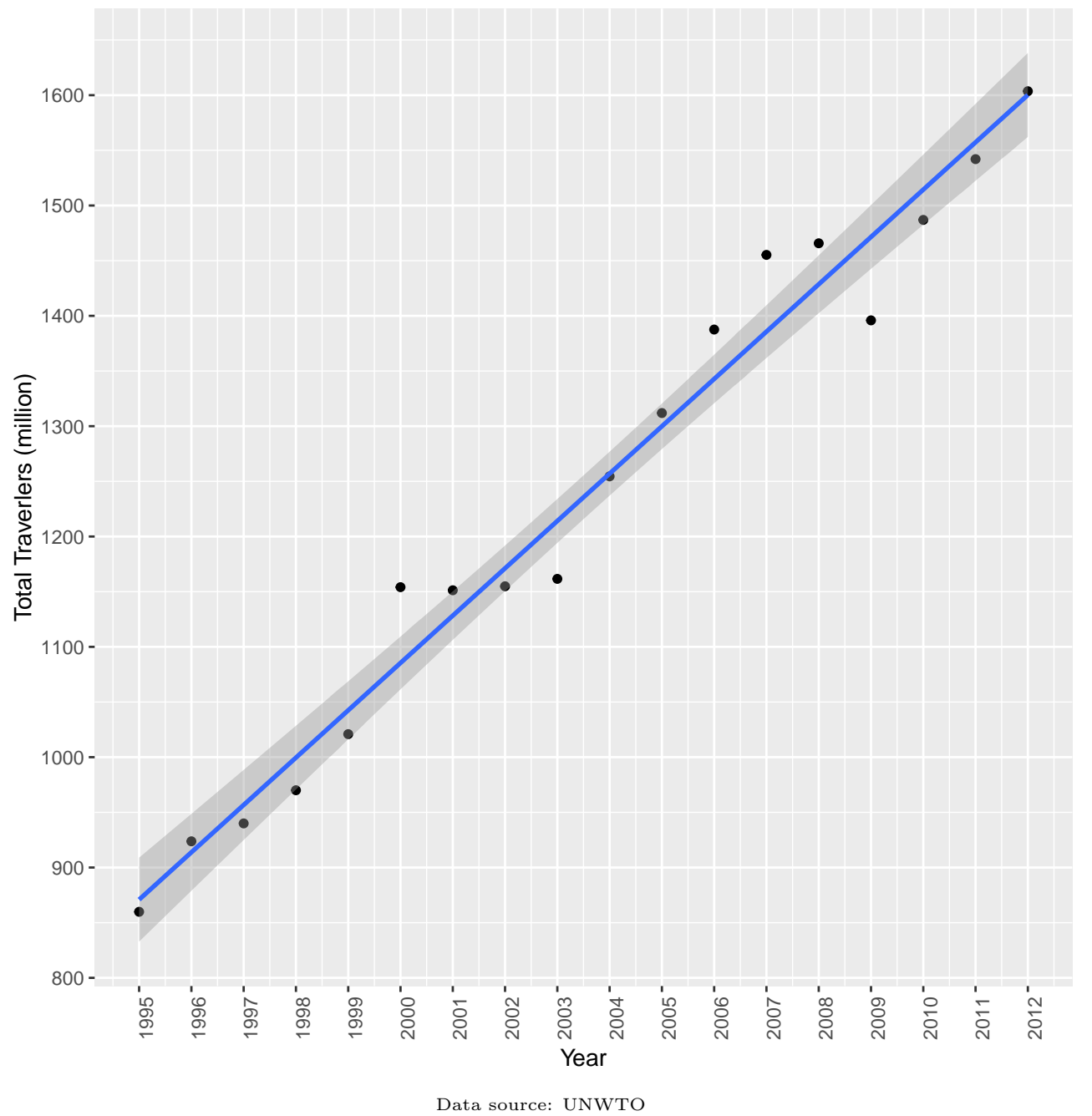


Figure 1.2: International Travel (annual percentage change)

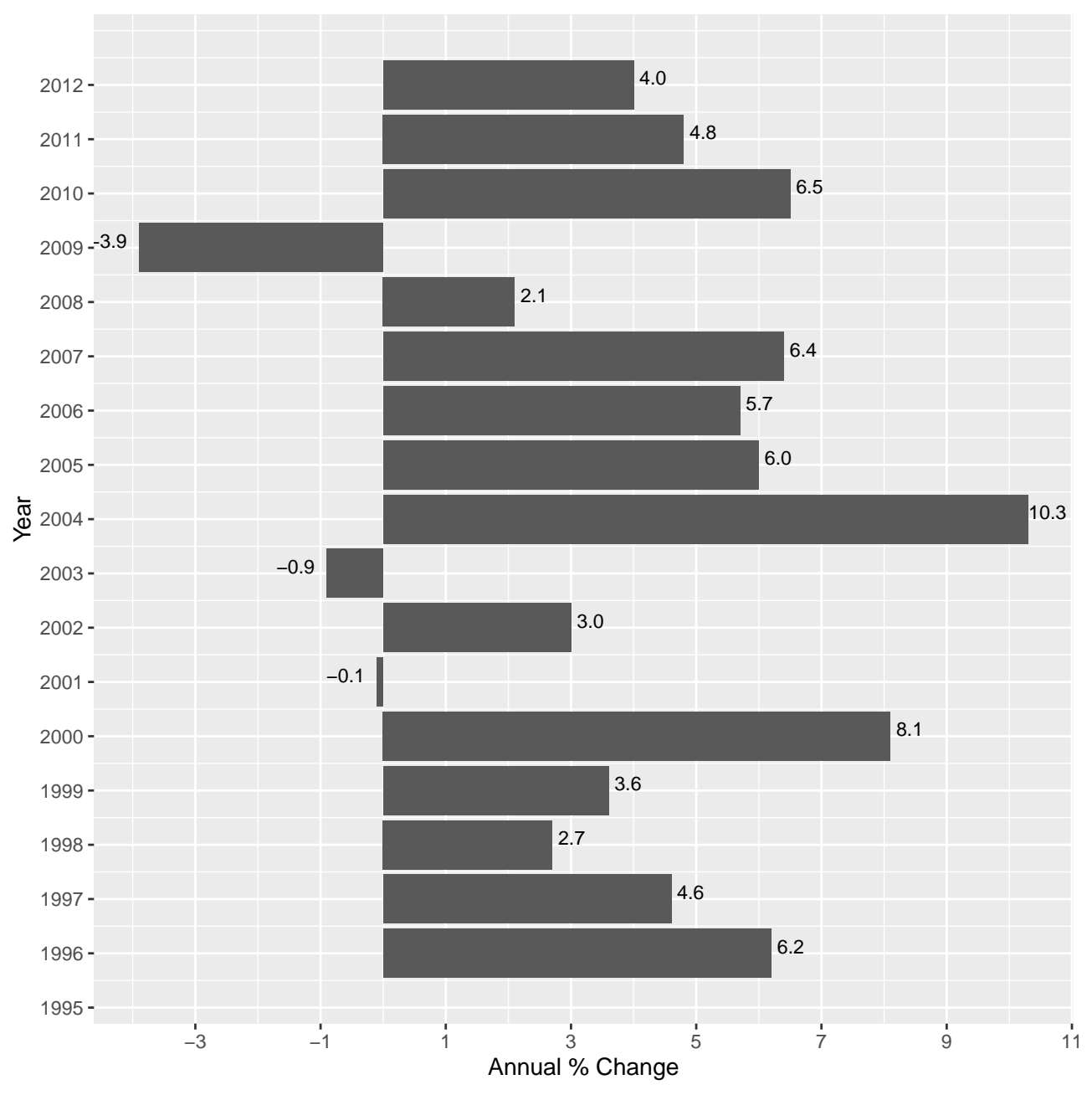

Source: UNWTO Annual Report 2013 
Figure 1.3: Top Ten Destination Countries for International Travel (in 2012)

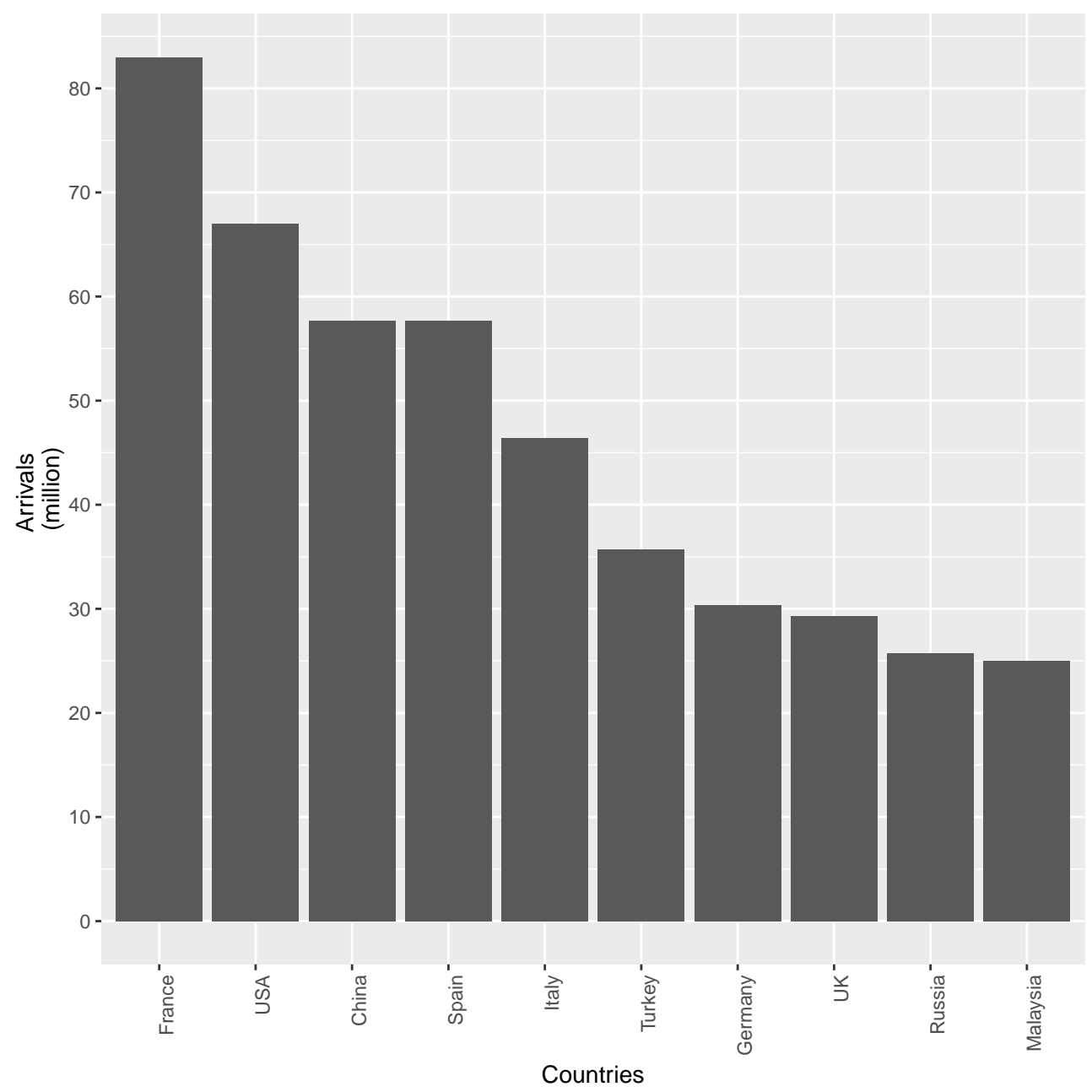

Source: UNWTO Tourism Highlights 2013 Edition. 
Figure 1.4: Top Ten Origin Countries for International Travel (in 2012)

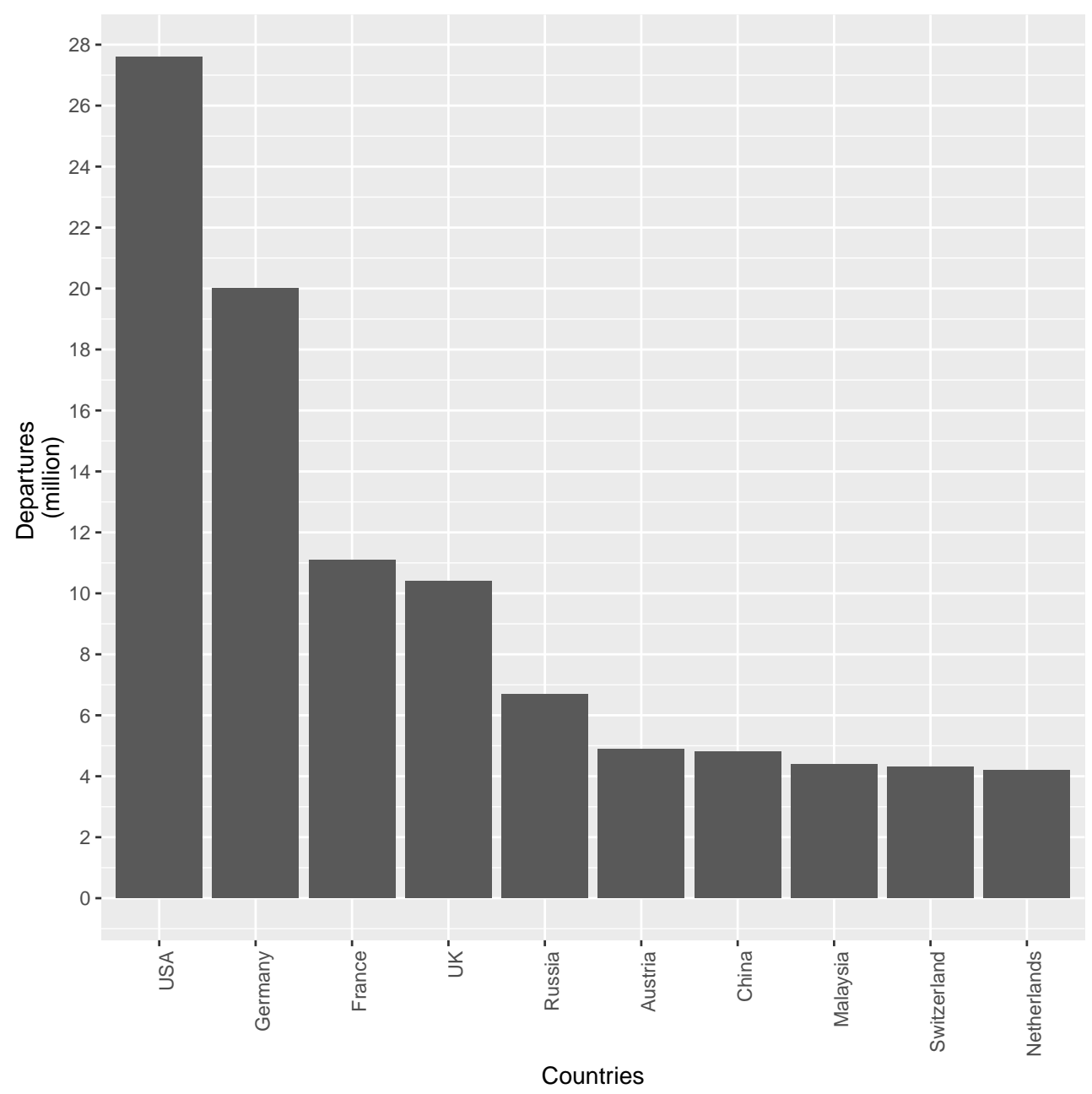

Notes: Author's own calculations, based on the UNWTO data 
Figure 1.5: International Travel (Region-wise)
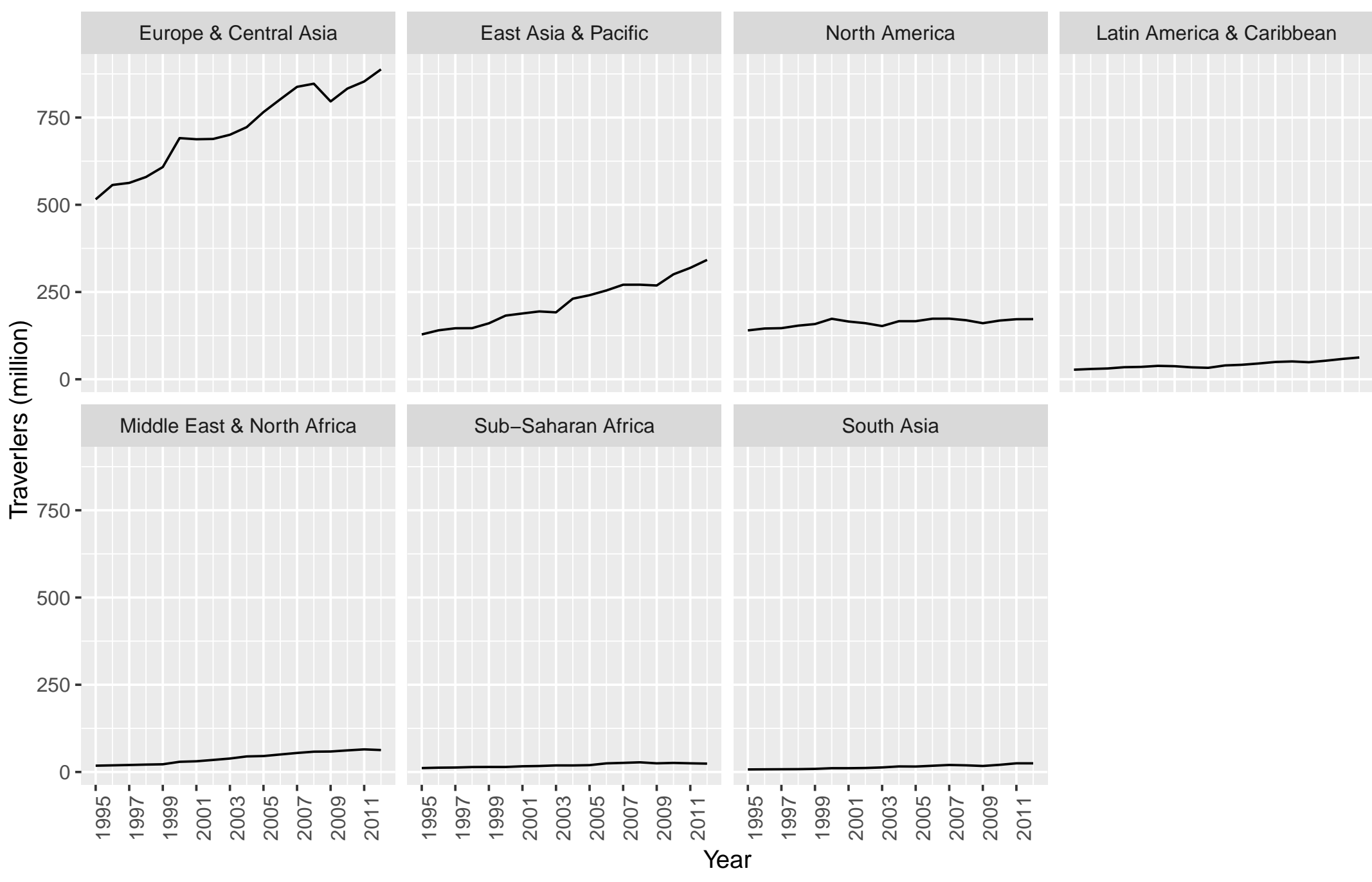
Figure 1.6: International Travel (Income Group-wise)

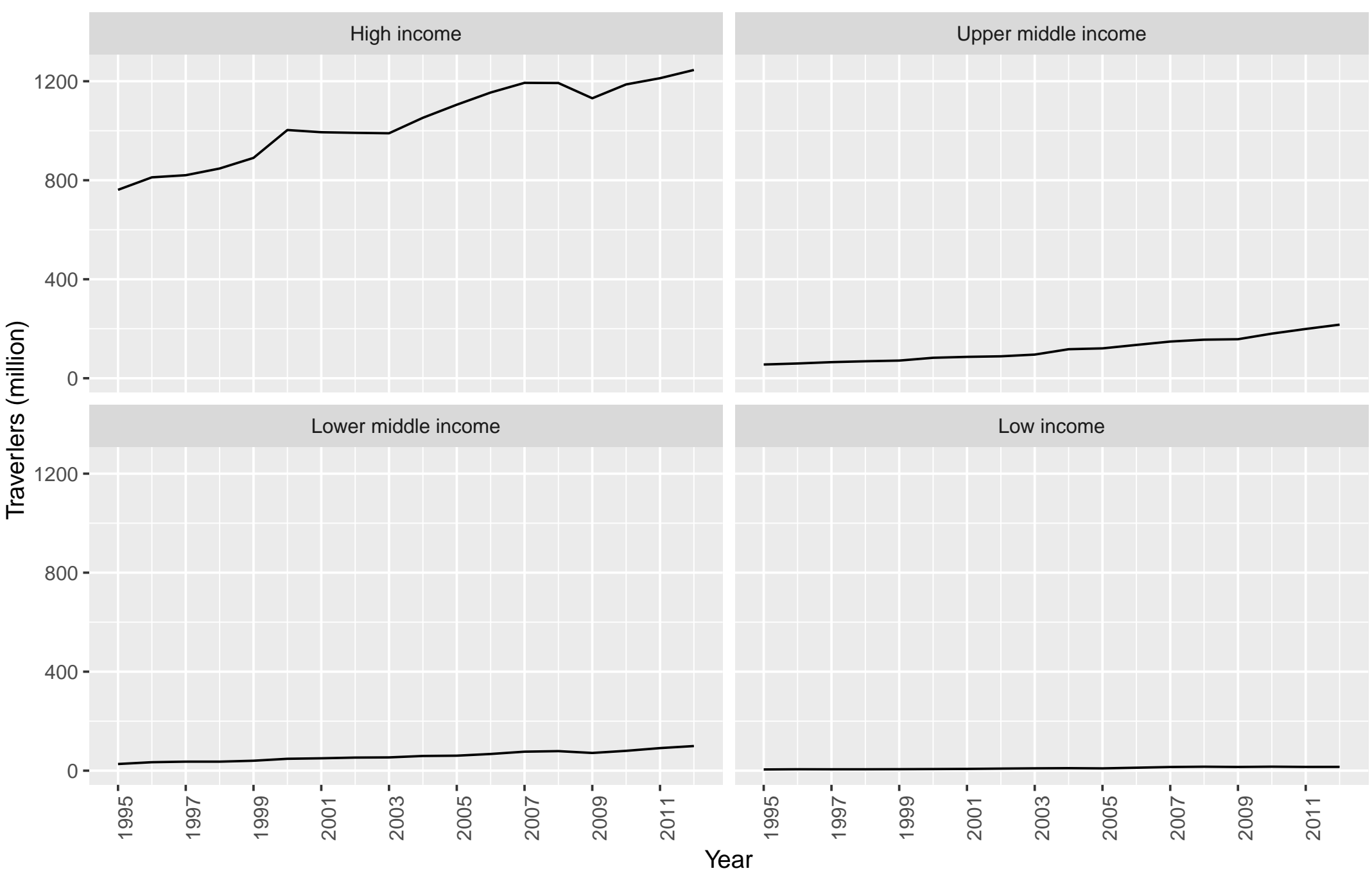

Notes: Income classifications are taken from the World Bank (see WDI) and the data source is the UNWTO 
Table 1.1: Descriptive Statistics

\begin{tabular}{lccccc}
\hline Statistic & N & Mean & St. Dev. & Min & Max \\
\hline Polity IV & 2509 & 0.68 & 0.32 & 0.00 & 1.00 \\
Political Rights & 2764 & 0.61 & 0.36 & 0.00 & 1.00 \\
Civil Liberties & 2764 & 0.61 & 0.30 & 0.00 & 1.00 \\
ln(Travel) & 2950 & -2.24 & 1.90 & -7.22 & 2.12 \\
Polity in Host Countries & 2950 & 0.70 & 0.23 & 0.02 & 1.00 \\
Political Rights in Host Countries & 2950 & 0.61 & 0.27 & 0.02 & 1.00 \\
Civil Liberties in Host Countries & 2950 & 0.60 & 0.24 & 0.02 & 1.00 \\
ln(Students) & 2950 & -7.51 & 1.81 & -16.51 & -3.22 \\
Infant Mortality Rate & 2906 & 34.69 & 31.70 & 1.60 & 158.30 \\
$\ln ($ Life Expectancy) & 2864 & 4.21 & 0.16 & 3.45 & 4.42 \\
Urbanization Rate & 2949 & 2.23 & 2.07 & -4.36 & 17.90 \\
$\ln ($ GDP per capita) & 2866 & 8.08 & 1.63 & 4.17 & 11.64 \\
Primary Education & 2946 & 5.68 & 0.90 & 3 & 8 \\
\hline
\end{tabular}


Table 1.2: Dependent Variable: Polity IV Index (OLS)

\begin{tabular}{|c|c|c|c|}
\hline & (1) & $(2)$ & $(3)$ \\
\hline VARIABLES & OLS & OLS & OLS \\
\hline \multirow[t]{2}{*}{$\ln \left(\right.$ Travel $\left._{i t-5}\right)$} & $-0.026^{* * *}$ & $-0.027^{* * *}$ & $-0.029 * * *$ \\
\hline & $(0.008)$ & $(0.009)$ & $(0.009)$ \\
\hline \multirow[t]{2}{*}{ Polity IV Index $i t-5$} & $0.488^{* * *}$ & $0.524^{* * *}$ & $0.513^{* * *}$ \\
\hline & $(0.019)$ & $(0.019)$ & $(0.019)$ \\
\hline \multirow[t]{2}{*}{ Average Polity in Host Countries $i t-5$} & $0.361^{* * *}$ & $0.353^{* * *}$ & $0.343^{* * *}$ \\
\hline & $(0.041)$ & $(0.040)$ & $(0.041)$ \\
\hline \multirow[t]{2}{*}{ Average Polity in Host Countries $i t-5 * \ln \left(\right.$ Travel $\left._{i t-5}\right)$} & $0.067^{* * *}$ & $0.064^{* * *}$ & $0.061^{* * *}$ \\
\hline & $(0.011)$ & $(0.011)$ & $(0.011)$ \\
\hline \multirow[t]{2}{*}{$\ln (\text { Students })_{i t-5}$} & & -0.002 & -0.002 \\
\hline & & $(0.002)$ & $(0.002)$ \\
\hline \multirow[t]{2}{*}{$\ln ($ GDP per capita $i t-5)$} & & 0.001 & -0.004 \\
\hline & & $(0.005)$ & $(0.006)$ \\
\hline \multirow[t]{2}{*}{ Primary Education $_{i t-5}$} & & $0.010^{*}$ & $0.014^{* *}$ \\
\hline & & $(0.005)$ & $(0.006)$ \\
\hline \multirow[t]{2}{*}{ 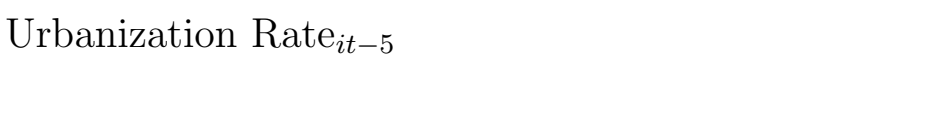 } & & & $-0.012^{* *}$ \\
\hline & & & $(0.005)$ \\
\hline \multirow[t]{2}{*}{ Infant Mortality Rate $_{i t-5}$} & & & -0.013 \\
\hline & & & $(0.014)$ \\
\hline \multirow[t]{2}{*}{ Life Expectancy $_{i t-5}$} & & & -0.000 \\
\hline & & & $(0.013)$ \\
\hline \multirow[t]{2}{*}{ Constant } & $0.150^{* * *}$ & $0.106^{*}$ & $0.145^{* *}$ \\
\hline & $(0.032)$ & $(0.057)$ & $(0.062)$ \\
\hline Observations & 1,746 & 1,722 & 1,721 \\
\hline R-squared & 0.797 & 0.808 & 0.804 \\
\hline Number of countries & 149 & 145 & 145 \\
\hline
\end{tabular}

Notes: ${ }^{* * *} \mathrm{p}<0.01,{ }^{* *} \mathrm{p}<0.05,{ }^{*} \mathrm{p}<0.1$. Robust standard errors in parentheses. The dependent variable is polity iv index. Ordinary least squares estimates. The sample is an unbalanced panel comprising annual data between 1995-2012. 
Table 1.3: Bilateral Travel Gravity Equation

\begin{tabular}{|c|c|c|}
\hline VARIABLES & $\ln \left(\right.$ Travel $\left._{i, j t}\right)$ & Interaction with Contiguity \\
\hline $\ln \left(\right.$ Distance $\left._{i, j}\right)$ & $\begin{array}{c}-1.540^{* * *} \\
(0.007)\end{array}$ & $\begin{array}{l}0.300^{* * *} \\
(0.085)\end{array}$ \\
\hline $\ln \left(\right.$ Population $\left._{i, t}\right)$ & $\begin{array}{c}-0.653^{* * *} \\
(0.051)\end{array}$ & $\begin{array}{r}-0.092 \\
(0.113)\end{array}$ \\
\hline $\ln \left(\right.$ Population $\left._{j, t}\right)$ & $\begin{array}{c}0.334^{* * *} \\
(0.051)\end{array}$ & $\begin{array}{l}0.055 \\
(0.113)\end{array}$ \\
\hline $\ln \left(\right.$ Area $\left._{i}\right)$ & $\begin{array}{c}-0.012^{* * *} \\
(0.005)\end{array}$ & $\begin{array}{l}-0.219^{* * *} \\
(0.035)\end{array}$ \\
\hline $\ln \left(\right.$ Area $\left._{j}\right)$ & $\begin{array}{c}0.245^{* * *} \\
(0.002)\end{array}$ & $\begin{array}{l}0.172^{* * *} \\
(0.031)\end{array}$ \\
\hline Landlocked $_{i}$ & $\begin{array}{c}-1.101^{* * *} \\
(0.018)\end{array}$ & $\begin{array}{l}0.960^{* * *} \\
(0.072)\end{array}$ \\
\hline Landlocked $_{j}$ & $\begin{array}{c}-1.263^{* * *} \\
(0.021)\end{array}$ & $\begin{array}{l}0.524^{* * *} \\
(0.075)\end{array}$ \\
\hline Contiguity $_{i, j}$ & $\begin{array}{c}0.349 \\
(0.389)\end{array}$ & \\
\hline Observations & 185,775 & \\
\hline R-squared & 0.322 & \\
\hline Time effects? & Yes & \\
\hline
\end{tabular}

Notes: $* * * \mathrm{p}<0.01,{ }^{* *} \mathrm{p}<0.05{ }^{*} \mathrm{p}<0.1$. Robust standard errors in parentheses. Pooled OLS estimates. The dependent variable is the total number of international travelers as a share of population, from country $i$ to country $j$. The sample is an unbalanced panel comprising bilateral annual data between 1995-2012. 
Table 1.4: Dependent Variable: Polity IV Index (2SLS)

\begin{tabular}{|c|c|c|c|}
\hline & (1) & $(2)$ & $(3)$ \\
\hline VARIABLES & TSLS & TSLS & TSLS \\
\hline \multirow[t]{2}{*}{$\ln \left(\right.$ Travel $\left._{i t-5}\right)$} & -0.016 & $-0.047^{*}$ & $-0.045^{*}$ \\
\hline & $(0.028)$ & $(0.026)$ & $(0.027)$ \\
\hline \multirow[t]{2}{*}{ Polity IV Index $i t-5$} & $0.857^{* * *}$ & $0.849^{* * *}$ & $0.846^{* * *}$ \\
\hline & $(0.013)$ & $(0.013)$ & $(0.014)$ \\
\hline \multirow[t]{2}{*}{ Average Polity in Host Countries $i t-5$} & 0.127 & $0.235^{* * *}$ & $0.222^{* * *}$ \\
\hline & $(0.090)$ & $(0.072)$ & $(0.077)$ \\
\hline \multirow[t]{2}{*}{ Average Polity in Host Countries $i t-5 * \ln \left(\operatorname{Travel}_{i t-5}\right)$} & 0.025 & $0.068^{* *}$ & $0.064^{* *}$ \\
\hline & $(0.037)$ & $(0.029)$ & $(0.030)$ \\
\hline \multirow[t]{2}{*}{$\ln (\text { Students })_{i t-5}$} & & -0.000 & -0.000 \\
\hline & & $(0.002)$ & $(0.002)$ \\
\hline \multirow[t]{2}{*}{$\ln ($ GDP per capita $i t-5)$} & & -0.004 & -0.006 \\
\hline & & $(0.005)$ & $(0.005)$ \\
\hline \multirow[t]{2}{*}{ Primary Education $_{i t-5}$} & & $0.007^{*}$ & $0.009 * *$ \\
\hline & & $(0.004)$ & $(0.004)$ \\
\hline \multirow[t]{2}{*}{ Urbanization Rate $_{i t-5}$} & & & -0.006 \\
\hline & & & $(0.005)$ \\
\hline \multirow[t]{2}{*}{ Infant Mortality Rate $_{i t-5}$} & & & -0.004 \\
\hline & & & $(0.012)$ \\
\hline \multirow[t]{2}{*}{ Life Expectancy $i t-5$} & & & -0.001 \\
\hline & & & $(0.009)$ \\
\hline \multirow[t]{2}{*}{ Constant } & 0.029 & -0.020 & 0.001 \\
\hline & $(0.072)$ & $(0.094)$ & $(0.088)$ \\
\hline Observations & 1,708 & 1,699 & 1,698 \\
\hline R-squared & 0.843 & 0.841 & 0.841 \\
\hline
\end{tabular}

Notes: ${ }^{* * *} \mathrm{p}<0.01,{ }^{* *} \mathrm{p}<0.05,{ }^{*} \mathrm{p}<0.1$. Robust standard errors in parentheses. The dependent variable is Polity IV index. Two-stage least squares estimates. The predicted values of variable travel are used as an instrument for the travel. The sample is an unbalanced panel comprising annual data between 1995-2012. 
Table 1.5: Dependent Variable: Political Rights Index (2SLS)

\begin{tabular}{|c|c|c|c|}
\hline & (1) & $(2)$ & $(3)$ \\
\hline VARIABLES & TSLS & TSLS & TSLS \\
\hline \multirow[t]{2}{*}{$\ln \left(\right.$ Travel $\left._{i t-5}\right)$} & $-0.037 * *$ & $-0.049 * * *$ & $-0.046^{* *}$ \\
\hline & $(0.016)$ & $(0.017)$ & $(0.018)$ \\
\hline \multirow[t]{2}{*}{ Political Rights Index $(\mathrm{PR})_{i t-5}$} & $0.857^{* * *}$ & $0.851^{* * *}$ & $0.837^{* * *}$ \\
\hline & $(0.012)$ & $(0.012)$ & $(0.013)$ \\
\hline \multirow[t]{2}{*}{ Average PR in Host Countries $i t-5$} & $0.202^{* * *}$ & $0.201^{* * *}$ & $0.211^{* * *}$ \\
\hline & $(0.051)$ & $(0.045)$ & $(0.049)$ \\
\hline \multirow{2}{*}{ Average PR in Host Countries ${ }_{i t-5}{ }^{*} \ln \left(\operatorname{Travel}_{i t-5}\right)$} & $0.065^{* * *}$ & $0.068^{* * *}$ & $0.066^{* * *}$ \\
\hline & $(0.022)$ & $(0.019)$ & $(0.020)$ \\
\hline \multirow[t]{2}{*}{$\ln (\text { Students })_{i t-5}$} & & 0.002 & 0.001 \\
\hline & & $(0.002)$ & $(0.002)$ \\
\hline \multirow[t]{2}{*}{$\ln ($ GDP per capita $i t-5)$} & & $0.014^{* *}$ & 0.002 \\
\hline & & $(0.006)$ & $(0.005)$ \\
\hline \multirow[t]{2}{*}{ Primary Education $_{i t-5}$} & & 0.003 & $0.009^{* *}$ \\
\hline & & $(0.004)$ & $(0.004)$ \\
\hline \multirow[t]{2}{*}{ Urbanization Rate $i t-5$} & & & -0.002 \\
\hline & & & $(0.004)$ \\
\hline \multirow[t]{2}{*}{ Infant Mortality Rate $_{i t-5}$} & & & 0.001 \\
\hline & & & $(0.013)$ \\
\hline \multirow[t]{2}{*}{ Life Expectancy $i t-5$} & & & $0.021^{* *}$ \\
\hline & & & $(0.010)$ \\
\hline \multirow[t]{2}{*}{ Constant } & -0.037 & $-0.155^{* *}$ & -0.055 \\
\hline & $(0.043)$ & $(0.075)$ & $(0.071)$ \\
\hline Observations & 1,822 & 1,812 & 1,788 \\
\hline R-squared & 0.845 & 0.843 & 0.843 \\
\hline
\end{tabular}

Notes: $* * * \mathrm{p}<0.01,{ }^{*} \mathrm{p}<0.05, * \mathrm{p}<0.1$. Robust standard errors in parentheses. The dependent variable is political rights index. Two-stage least squares estimates. The predicted values of variable travel are used as an instrument for the travel. The sample is an unbalanced panel comprising annual data between 1995-2012. 
Table 1.6: Dependent Variable: Civil Liberties Index (2SLS)

\begin{tabular}{|c|c|c|c|}
\hline & (1) & $(2)$ & $(3)$ \\
\hline VARIABLES & TSLS & TSLS & TSLS \\
\hline \multirow[t]{2}{*}{$\ln \left(\right.$ Travel $\left._{i t-5}\right)$} & $-0.030^{* *}$ & $-0.039 * * *$ & $-0.035^{* *}$ \\
\hline & $(0.013)$ & $(0.014)$ & $(0.015)$ \\
\hline \multirow[t]{2}{*}{ Civil Rights Index $(\mathrm{CL})_{i t-5}$} & $0.902^{* * *}$ & $0.900^{* * *}$ & $0.883^{* * *}$ \\
\hline & $(0.011)$ & $(0.012)$ & $(0.012)$ \\
\hline \multirow[t]{2}{*}{ Average CL in Host Countries $i t-5$} & $0.138^{* * *}$ & $0.146^{* * *}$ & $0.147^{* * *}$ \\
\hline & $(0.045)$ & $(0.038)$ & $(0.042)$ \\
\hline \multirow[t]{2}{*}{ Average CL in Host Countries $i t-5 * \ln \left(\operatorname{Travel}_{i t-5}\right)$} & $0.051^{* * *}$ & $0.054^{* * *}$ & $0.049^{* * *}$ \\
\hline & $(0.019)$ & $(0.016)$ & $(0.017)$ \\
\hline \multirow[t]{2}{*}{$\ln (\text { Students })_{i t-5}$} & & 0.002 & 0.001 \\
\hline & & $(0.002)$ & $(0.002)$ \\
\hline \multirow[t]{2}{*}{$\ln ($ GDP per capita $i t-5)$} & & $0.010^{* *}$ & 0.000 \\
\hline & & $(0.004)$ & $(0.004)$ \\
\hline \multirow[t]{2}{*}{ Primary Education $_{i t-5}$} & & $-0.007 * * *$ & -0.002 \\
\hline & & $(0.003)$ & $(0.003)$ \\
\hline \multirow[t]{2}{*}{ Urbanization Rate $_{i t-5}$} & & & $-0.006^{* *}$ \\
\hline & & & $(0.003)$ \\
\hline \multirow[t]{2}{*}{ Infant Mortality Rate $_{i t-5}$} & & & -0.008 \\
\hline & & & $(0.010)$ \\
\hline \multirow[t]{2}{*}{ Life Expectancy ${ }_{i t-5}$} & & & 0.008 \\
\hline & & & $(0.007)$ \\
\hline \multirow[t]{2}{*}{ Constant } & -0.004 & -0.089 & -0.009 \\
\hline & $(0.035)$ & $(0.056)$ & $(0.052)$ \\
\hline Observations & 1,822 & 1,812 & 1,788 \\
\hline R-squared & 0.877 & 0.876 & 0.877 \\
\hline
\end{tabular}

Notes: ${ }^{* * *} \mathrm{p}<0.01,{ }^{* *} \mathrm{p}<0.05,{ }^{*} \mathrm{p}<0.1$. Robust standard errors in parentheses. The dependent variable is civil liberties index. Two-stage least squares estimates. The predicted values of variable travel are used as an instrument for the travel. The sample is an unbalanced panel comprising annual data between 1995-2012. 
Table 1.7: Institutional Convergence (System GMM)

\begin{tabular}{lccc}
\hline & $(1)$ & $(2)$ & $(3)$ \\
VARIABLES & Polity IV & Political Rights & Civil Liberties \\
\hline Institutions $_{t-1}$ & $0.888^{* * *}$ & $0.862^{* * *}$ & $0.928^{* * *}$ \\
& $(0.039)$ & $(0.047)$ & $(0.028)$ \\
Travel ${ }_{t-1}$ & 0.004 & -0.010 & -0.004 \\
& $(0.012)$ & $(0.011)$ & $(0.006)$ \\
Average Institutions in Host Countries $_{t-1}$ & 0.093 & $0.096^{*}$ & 0.007 \\
& $(0.060)$ & $(0.051)$ & $(0.032)$ \\
Average Institutions in Host Countries $_{t-1}{ }^{*}$ Travel & -0.008 & 0.007 & 0.005 \\
& $(0.016)$ & $(0.017)$ & $(0.010)$ \\
Constant & & & 0.027 \\
& -0.008 & 0.108 & $(0.020)$ \\
Time Effects & $(0.088)$ & $(0.103)$ & Yes \\
\hline Observations & & & 2,422 \\
Number of countries & Yes & Yes & -0.06 \\
\hline
\end{tabular}

Notes: $* * * \mathrm{p}<0.01,{ }^{* *} \mathrm{p}<0.05,{ }^{*} \mathrm{p}<0.1$. System GMM estimates. The dependent variable is polity iv in column 1, political rights in column 2, and civil liberties in column3. Long-run elasticity (Travel)=beta (Travel $\left.{ }_{t-1}\right) /\left(1-\right.$ beta(Institutions $\left.{ }_{t-1}\right)$. The sample is an unbalanced panel comprising annual data between 1995-2012. 
Table 1.8: Correlation Matrix

\begin{tabular}{|c|c|c|c|c|c|c|c|c|c|c|c|c|}
\hline Polity IV & 1 & & & & & & & & & & & \\
\hline Political Rights & 0.94 & 1 & & & & & & & & & & \\
\hline Civil Liberties & 0.91 & 0.94 & 1 & & & & & & & & & \\
\hline Travel & 0.62 & 0.61 & 0.66 & 1 & & & & & & & & \\
\hline Polity in Host Countries & 0.61 & 0.62 & 0.64 & 0.56 & 1 & & & & & & & \\
\hline Political Rights in Host Countries & 0.63 & 0.64 & 0.65 & 0.53 & 0.91 & 1 & & & & & & \\
\hline Civil Liberties in Host Countries & 0.65 & 0.66 & 0.69 & 0.54 & 0.87 & 0.95 & 1 & & & & & \\
\hline Students & 0.29 & 0.29 & 0.32 & 0.56 & 0.22 & 0.19 & 0.22 & 1 & & & & \\
\hline Infant Mortality Rate & -0.65 & -0.65 & -0.67 & -0.81 & -0.52 & -0.52 & -0.56 & -0.45 & 1 & & & \\
\hline Life Expectancy & 0.61 & 0.6 & 0.62 & 0.74 & 0.47 & 0.49 & 0.53 & 0.39 & -0.94 & 1 & & \\
\hline Urbanization Rate & -0.45 & -0.46 & -0.44 & -0.58 & -0.43 & -0.36 & -0.37 & -0.36 & 0.64 & -0.52 & 1 & \\
\hline GDP per capita & 0.63 & 0.64 & 0.67 & 0.82 & 0.51 & 0.54 & 0.6 & 0.48 & -0.92 & 0.9 & -0.51 & 1 \\
\hline Primary Education & 0.11 & 0.12 & 0.16 & 0.01 & 0.1 & 0.2 & 0.22 & 0.01 & 0.02 & 0.03 & 0.32 & 0.14 \\
\hline
\end{tabular}


Table 1.9: Region-wise Travel Patterns (in million)

\begin{tabular}{|c|c|c|c|c|c|c|c|c|}
\hline Year & $\begin{array}{c}\text { East Asia \& } \\
\text { Pacific }\end{array}$ & $\begin{array}{c}\text { Europe \& } \\
\text { Central Asia }\end{array}$ & $\begin{array}{c}\text { Latin } \\
\text { America \& } \\
\text { Caribbean }\end{array}$ & $\begin{array}{c}\text { Middle East } \\
\text { \& North } \\
\text { Africa }\end{array}$ & $\begin{array}{l}\text { North } \\
\text { America }\end{array}$ & South Asia & $\begin{array}{c}\text { Sub-Saharan } \\
\text { Africa }\end{array}$ & $\begin{array}{c}\text { Total } \\
\text { Outbound }\end{array}$ \\
\hline 1995 & 128.50 & 515.56 & 27.42 & 18.08 & 140.03 & 7.34 & 11.31 & 848.23 \\
\hline 1996 & 140.25 & 556.75 & 29.44 & 19.06 & 145.48 & 7.63 & 12.39 & 911.00 \\
\hline 1997 & 146.17 & 562.70 & 30.90 & 20.05 & 146.45 & 7.87 & 12.82 & 926.96 \\
\hline 1998 & 146.43 & 579.65 & 34.59 & 21.22 & 153.68 & 8.12 & 14.17 & 957.85 \\
\hline 1999 & 160.33 & 608.10 & 35.45 & 22.13 & 158.24 & 8.90 & 14.42 & 1007.57 \\
\hline 2000 & 182.48 & 691.05 & 38.42 & 29.25 & 173.32 & 10.91 & 14.37 & 1139.80 \\
\hline 2001 & 188.56 & 687.74 & 37.43 & 30.74 & 165.48 & 10.89 & 16.39 & 1137.23 \\
\hline 2002 & 194.37 & 688.62 & 34.21 & 34.55 & 160.74 & 11.50 & 17.19 & 1141.18 \\
\hline 2003 & 191.76 & 700.62 & 32.78 & 38.61 & 152.43 & 13.06 & 18.83 & 1148.10 \\
\hline 2004 & 230.94 & 722.46 & 39.63 & 44.63 & 166.43 & 15.94 & 18.79 & 1238.82 \\
\hline 2005 & 240.91 & 765.56 & 41.47 & 45.74 & 166.44 & 15.65 & 19.62 & 1295.38 \\
\hline 2006 & 254.45 & 802.20 & 45.19 & 50.19 & 173.56 & 17.88 & 24.74 & 1368.20 \\
\hline 2007 & 270.93 & 837.97 & 49.57 & 54.59 & 173.69 & 20.12 & 26.16 & 1433.04 \\
\hline 2008 & 270.95 & 846.95 & 51.08 & 58.21 & 169.26 & 19.09 & 27.74 & 1443.27 \\
\hline 2009 & 268.75 & 796.11 & 48.80 & 58.76 & 160.66 & 17.28 & 24.80 & 1375.16 \\
\hline 2010 & 300.76 & 832.94 & 53.14 & 61.92 & 168.25 & 20.58 & 26.01 & 1463.60 \\
\hline 2011 & 319.24 & 853.25 & 58.31 & 64.81 & 172.07 & 24.85 & 24.90 & 1517.43 \\
\hline 2012 & 342.10 & 887.97 & 62.45 & 62.91 & 172.34 & 24.81 & 23.98 & 1576.56 \\
\hline Total & 3977.88 & 12936.20 & 750.27 & 735.44 & 2918.54 & 262.42 & 348.62 & 21929.37 \\
\hline
\end{tabular}


Table 1.10: Region-wise Travel Patterns (percentage share)

\begin{tabular}{|c|c|c|c|c|c|c|c|}
\hline Year & $\begin{array}{c}\text { East Asia \& } \\
\text { Pacific }\end{array}$ & $\begin{array}{c}\text { Europe \& } \\
\text { Central Asia }\end{array}$ & $\begin{array}{c}\text { Latin } \\
\text { America \& } \\
\text { Caribbean }\end{array}$ & $\begin{array}{c}\text { Middle East } \\
\text { \& North } \\
\text { Africa }\end{array}$ & $\begin{array}{c}\text { North } \\
\text { America }\end{array}$ & South Asia & $\begin{array}{c}\text { Sub-Saharan } \\
\text { Africa }\end{array}$ \\
\hline 1995 & $15.15 \%$ & $60.78 \%$ & $3.23 \%$ & $2.13 \%$ & $16.51 \%$ & $0.87 \%$ & $1.33 \%$ \\
\hline 1996 & $15.40 \%$ & $61.11 \%$ & $3.23 \%$ & $2.09 \%$ & $15.97 \%$ & $0.84 \%$ & $1.36 \%$ \\
\hline 1997 & $15.77 \%$ & $60.70 \%$ & $3.33 \%$ & $2.16 \%$ & $15.80 \%$ & $0.85 \%$ & $1.38 \%$ \\
\hline 1998 & $15.29 \%$ & $60.52 \%$ & $3.61 \%$ & $2.22 \%$ & $16.04 \%$ & $0.85 \%$ & $1.48 \%$ \\
\hline 1999 & $15.91 \%$ & $60.35 \%$ & $3.52 \%$ & $2.20 \%$ & $15.71 \%$ & $0.88 \%$ & $1.43 \%$ \\
\hline 2000 & $16.01 \%$ & $60.63 \%$ & $3.37 \%$ & $2.57 \%$ & $15.21 \%$ & $0.96 \%$ & $1.26 \%$ \\
\hline 2001 & $16.58 \%$ & $60.48 \%$ & $3.29 \%$ & $2.70 \%$ & $14.55 \%$ & $0.96 \%$ & $1.44 \%$ \\
\hline 2002 & $17.03 \%$ & $60.34 \%$ & $3.00 \%$ & $3.03 \%$ & $14.09 \%$ & $1.01 \%$ & $1.51 \%$ \\
\hline 2003 & $16.70 \%$ & $61.02 \%$ & $2.85 \%$ & $3.36 \%$ & $13.28 \%$ & $1.14 \%$ & $1.64 \%$ \\
\hline 2004 & $18.64 \%$ & $58.32 \%$ & $3.20 \%$ & $3.60 \%$ & $13.43 \%$ & $1.29 \%$ & $1.52 \%$ \\
\hline 2005 & $18.60 \%$ & $59.10 \%$ & $3.20 \%$ & $3.53 \%$ & $12.85 \%$ & $1.21 \%$ & $1.51 \%$ \\
\hline 2006 & $18.60 \%$ & $58.63 \%$ & $3.30 \%$ & $3.67 \%$ & $12.69 \%$ & $1.31 \%$ & $1.81 \%$ \\
\hline 2007 & $18.91 \%$ & $58.48 \%$ & $3.46 \%$ & $3.81 \%$ & $12.12 \%$ & $1.40 \%$ & $1.83 \%$ \\
\hline 2008 & $18.77 \%$ & $58.68 \%$ & $3.54 \%$ & $4.03 \%$ & $11.73 \%$ & $1.32 \%$ & $1.92 \%$ \\
\hline 2009 & $19.54 \%$ & $57.89 \%$ & $3.55 \%$ & $4.27 \%$ & $11.68 \%$ & $1.26 \%$ & $1.80 \%$ \\
\hline 2010 & $20.55 \%$ & $56.91 \%$ & $3.63 \%$ & $4.23 \%$ & $11.50 \%$ & $1.41 \%$ & $1.78 \%$ \\
\hline 2011 & $21.04 \%$ & $56.23 \%$ & $3.84 \%$ & $4.27 \%$ & $11.34 \%$ & $1.64 \%$ & $1.64 \%$ \\
\hline 2012 & $21.70 \%$ & $56.32 \%$ & $3.96 \%$ & $3.99 \%$ & $10.93 \%$ & $1.57 \%$ & $1.52 \%$ \\
\hline Total & $18.14 \%$ & $58.99 \%$ & $3.42 \%$ & $3.35 \%$ & $13.31 \%$ & $1.20 \%$ & $1.59 \%$ \\
\hline
\end{tabular}


Table 1.11: Travel Patterns (Income Group-wise)

\begin{tabular}{c|cc|cc|cc|cc|c}
\hline Year & \multicolumn{2}{|c|}{ High income } & \multicolumn{2}{|c}{ Low income } & Lower middle income & Upper middle income & Total \\
\hline & (Million) & (\%Share) & (Million) & (\%Share) & (Million) & (\%Share) & (Million) & (\%Share) & \\
1995 & 761.22 & $89.74 \%$ & $477.69 \%$ & $0.56 \%$ & 26.80 & $3.16 \%$ & 55.44 & $6.54 \%$ & 848.23 \\
1996 & 811.71 & $89.10 \%$ & $557.95 \%$ & $0.61 \%$ & 34.13 & $3.75 \%$ & 59.58 & $6.54 \%$ & 911.00 \\
1997 & 820.29 & $88.49 \%$ & $536.95 \%$ & $0.58 \%$ & 36.32 & $3.92 \%$ & 64.98 & $7.01 \%$ & 926.96 \\
1998 & 847.42 & $88.47 \%$ & $549.70 \%$ & $0.57 \%$ & 36.36 & $3.80 \%$ & 68.57 & $7.16 \%$ & 957.85 \\
1999 & 890.36 & $88.37 \%$ & $587.12 \%$ & $0.58 \%$ & 40.03 & $3.97 \%$ & 71.32 & $7.08 \%$ & 1007.57 \\
2000 & 1002.91 & $87.99 \%$ & $637.14 \%$ & $0.56 \%$ & 47.93 & $4.20 \%$ & 82.60 & $7.25 \%$ & 1139.80 \\
2001 & 993.97 & $87.40 \%$ & $701.62 \%$ & $0.62 \%$ & 49.94 & $4.39 \%$ & 86.30 & $7.59 \%$ & 1137.23 \\
2002 & 991.58 & $86.89 \%$ & $826.59 \%$ & $0.72 \%$ & 52.79 & $4.63 \%$ & 88.54 & $7.76 \%$ & 1141.18 \\
2003 & 989.77 & $86.21 \%$ & $933.84 \%$ & $0.81 \%$ & 53.49 & $4.66 \%$ & 95.51 & $8.32 \%$ & 1148.10 \\
2004 & 1052.34 & $84.95 \%$ & $1001.07 \%$ & $0.81 \%$ & 59.28 & $4.79 \%$ & 117.18 & $9.46 \%$ & 1238.82 \\
2005 & 1105.15 & $85.31 \%$ & $919.63 \%$ & $0.71 \%$ & 60.43 & $4.67 \%$ & 120.60 & $9.31 \%$ & 1295.38 \\
2006 & 1154.44 & $84.38 \%$ & $1188.27 \%$ & $0.87 \%$ & 67.36 & $4.92 \%$ & 134.52 & $9.83 \%$ & 1368.20 \\
2007 & 1193.52 & $83.29 \%$ & $1465.11 \%$ & $1.02 \%$ & 76.64 & $5.35 \%$ & 148.22 & $10.34 \%$ & 1433.04 \\
2008 & 1192.79 & $82.64 \%$ & $1591.11 \%$ & $1.10 \%$ & 78.82 & $5.46 \%$ & 155.76 & $10.79 \%$ & 1443.27 \\
2009 & 1131.17 & $82.26 \%$ & $1489.84 \%$ & $1.08 \%$ & 71.52 & $5.20 \%$ & 157.57 & $11.46 \%$ & 1375.16 \\
2010 & 1187.22 & $81.12 \%$ & $1602.64 \%$ & $1.10 \%$ & 80.08 & $5.47 \%$ & 180.27 & $12.32 \%$ & 1463.60 \\
2011 & 1212.26 & $79.89 \%$ & $1505.82 \%$ & $0.99 \%$ & 91.12 & $6.00 \%$ & 199.00 & $13.11 \%$ & 1517.43 \\
2012 & 1245.56 & $79.00 \%$ & $1519.04 \%$ & $0.96 \%$ & 99.36 & $6.30 \%$ & 216.45 & $13.73 \%$ & 1576.56 \\
\hline Total & 18583.67 & $84.74 \%$ & $18091.15 \%$ & $0.82 \%$ & 1062.40 & $4.84 \%$ & 2102.39 & $9.59 \%$ & 21929.37 \\
\hline
\end{tabular}


Table 1.12: List of Countries in the Sample

\begin{tabular}{|c|c|c|c|c|}
\hline Afghanistan & Colombia & Iceland & Mozambique & Slovenia \\
\hline Albania & Comoros & India & Oman & Somalia \\
\hline Algeria & Congo, Rep. & Indonesia & Namibia & South Africa \\
\hline Andorra & Costa Rica & Iran, Islamic Rep. & Nepal & Zimbabwe \\
\hline Angola & Croatia & Iraq & Netherlands & Spain \\
\hline Antigua and Barbuda & Cuba & Ireland & Aruba & Swaziland \\
\hline Azerbaijan & Cyprus & Israel & Vanuatu & Sweden \\
\hline Argentina & Czech Republic & Italy & New Zealand & Switzerland \\
\hline Australia & Benin & Cote d'Ivoire & Nicaragua & Syrian Arab Republic \\
\hline Austria & Denmark & Jamaica & Niger & Tajikistan \\
\hline Bahamas, The & Dominica & Japan & Nigeria & Thailand \\
\hline Bahrain & Dominican Republic & Kazakhstan & Norway & Togo \\
\hline Bangladesh & Ecuador & Jordan & Palau & Tonga \\
\hline Armenia & El Salvador & Kenya & Pakistan & Trinidad and Tobago \\
\hline Barbados & Ethiopia & Korea, Dem. People's Rep. & Panama & United Arab Emirates \\
\hline Bermuda & Eritrea & Korea, Rep. & Papua New Guinea & Tunisia \\
\hline Bhutan & Estonia & Kuwait & Paraguay & Turkey \\
\hline Bolivia & Fiji & Kyrgyz Republic & Peru & Turkmenistan \\
\hline Bosnia and Herzegovina & Finland & Lebanon & Philippines & Tuvalu \\
\hline Botswana & France & Lesotho & Poland & Uganda \\
\hline Brazil & Djibouti & Latvia & Portugal & Ukraine \\
\hline Belize & Gabon & Liberia & Guinea-Bissau & Macedonia, FYR \\
\hline Brunei Darussalam & Georgia & Libya & Puerto Rico & Egypt, Arab Rep. \\
\hline Bulgaria & Gambia, The & Lithuania & Qatar & United Kingdom \\
\hline Myanmar & Germany & Luxembourg & Russian Federation & Tanzania \\
\hline Burundi & Ghana & Madagascar & Rwanda & United States \\
\hline Belarus & Greece & Malawi & San Marino & Uruguay \\
\hline Cambodia & Greenland & Malaysia & Sao Tome and Principe & Uzbekistan \\
\hline Cameroon & Grenada & Maldives & Saudi Arabia & Venezuela, RB \\
\hline Canada & Guatemala & Mali & Senegal & Samoa \\
\hline Central African Republic & Guinea & Malta & Seychelles & Yemen, Rep. \\
\hline Sri Lanka & Guyana & Mexico & Sierra Leone & Zambia \\
\hline Chad & Haiti & Mongolia & Singapore & \\
\hline Chile & Honduras & Moldova & Slovak Republic & \\
\hline China & Hungary & Morocco & Vietnam & \\
\hline
\end{tabular}




\section{Chapter 2}

\section{Foreign Education, Technology Diffusion, and Productivity}

This paper investigates whether foreign qualified students bring new ideas and technical expertise from abroad, disperse them, and stimulate aggregate productivity in their home countries. An instrumental variable is derived from a fitted gravity equation model. An unbalanced panel data of 111 countries during the period 1950-2012 shows that foreign education has a statistically significant effect on technology diffusion. The results are robust across different sub-samples and to the inclusion of other channels of technology diffusion. These findings should prove helpful to policy makers in developing economies to adopt more open education policies and to increase public spending on foreign education.

\section{$2.1 \quad$ Introduction}

Differences in total factor productivity (TFP) explain a major part of the differences in income across countries, 1] but why does TFP differ across countries and what can be learned about the mechanisms through which technologies disperse across countries? Economic literature ascribes difference in total factor productivity to two factors: geographic factors and cross country movement of goods and services.2 Some countries are geographically closer to technological frontiers and can benefit from the technological progress of these

${ }^{1}$ see (Caselli, 2005; Klenow and Rodriguez-Clare, 1997; Hall and Jones, 1999)

${ }^{2}$ see Keller (2004) for the review of the literature. Also see Andersen and Dalgaard (2011) 
technology leaders.3 $3^{3}$ Cross country movement of goods and services is important because foreign technologies can be imported by the flows of goods and services across borders. To explore these channels of technology transfer, earlier research focuses on two channels of technology transfer: international trade ${ }^{4}$ and foreign direct investment (FDI).$^{5}$ This paper expands this literature and explores whether technologies diffuse across countries as a result of foreign education.

Relatively few studies have focused on the relationship between foreign education and technology transfer. To the author's knowledge, Park (2004) and Le (2010) are the only papers considering the R\&D spillover across countries via international student mobility. Park (2004) explores the relationship between international student flow and R\&D spillovers, and finds a positive and statistically significant role of foreign education on TFP in 21 OECD countries. Le (2010) finds strong evidence in favor of R\&D spillovers from developed countries to less developed countries during 1998-2005 as a result of student mobility.

This paper extends and improves Park (2004) and Le (2010) in the following ways. First, this paper uses a larger data set: both in terms of countries and time period. Foreign educated students need to graduate before returning to their home countries. The data set used in this study comprise of 111 countries during the period 1950-2012. This long observation period allows to test the long run effects of foreign education on technology diffusion as well as helps us understand the process of technology diffusion during different time periods. Second, this paper corrects for the likely endogeneity in the model using an instrumental variables method.

To empirically investigate the relationship between the technology diffusion and foreign education and to deal with the omitted variables and unobserved factors, this paper correct for endogeneity by constructing an instrument for foreign education. High TFP (advanced) countries may exchange more foreign students than low TFP (developing) countries due to reason unrelated to TFP. As we can see from figure 2.3 that top ten countries host more than 50 percent of total international students. All these countries have relatively high TFP

\footnotetext{
${ }^{3}$ see Howitt (2000) and Eaton and Kortum (2002). Also see Gallup et al. (1999).

${ }^{4}$ see for example Coe and Helpman (1995), Engelbrecht (1997), Keller (1998), Lee (2006), and Edmond (2001)

${ }^{5}$ see De La Potterie and Lichtenberg (2001) and Lee (2006).
} 
and are technologically advanced. Some unobserved factors can also affect foreign education as well as technology diffusion. For example, Spilimbergo (2009), Kim (1998), and Barnett and $\mathrm{Wu}(1995)$ argue that foreign education is motivated by geographic factors and bilateral links. Geographic factors are also correlated with technology diffusion (Diamond, 1999; Gallup et al., 1999; Andersen and Dalgaard, 2011). This shows that geographic factors can affect both technology level and foreign education.

To deal with this endogeneity, this paper constructs an instrument for the endogenous variable 'Students Abroad'. This instrument is constructed using bilateral student flows across countries and contains three explanatory variables: home country population, host country population, and the popularity of the destination country among international students. These variables show the choice of destination country by the international students. The popularity of the host country variable shows the total number of international students enrolled in the host country excluding students from the home country. These variables are valid instrument because they explain the choice of host country and do not affect technology level in the home country.

First stage pooled OLS results show that foreign education is strongly and positively correlated with host country population size and negatively correlated with home country population size. This shows that large countries, on average, attract more students, and small countries send more students abroad. Variable popularity of the host country captures the popularity of the destination country among international students. The results show that popularity of the host country (among international students) is a statistically significant determinant of bilateral flows of students. International students are 65 percent more likely to choose the same host country which other students are choosing. The fitted values of bilateral flows of people are then summed up and used as an instrument for student abroad.

Two-stage least squares estimates show that foreign education has a statistically significant and positive effect on TFP. The TFP has an elasticity of 0.04 with respect to student abroad. These results are robust across different time periods and to the inclusion of other channels of technology diffusion: trade flow and foreign direct investment. These findings support the main hypothesis of this paper that foreign education is a significant source of technology diffusion and productivity growth for the home country. Foreign-educated indi- 
viduals learn new ideas while studying abroad, bring new knowledge to their home countries, promote technology diffusion, and boost productivity growth.

Rest of the paper is organized as follows: section 2.2 highlights the channels through which foreign education helps international technology diffusion, section 2.3 describes the data, section 2.4 presents the empirical methodology and estimation results, and section 2.5 concludes this paper.

\subsection{How Does Foreign Education Help Technology Dif- fusion?}

So how does foreign education helps cross country technology diffusion? Foreign education increases human interaction and help foreign students learn tacit part of new technologies. Many authors believe that a major part of knowledge is tacit in nature and some type of human interaction is required to learn this tacit technology ${ }^{6}$. Learning by interaction and imitation is not a new concept. For example, Arrow (1969) argues that technological knowledge transfers through human international, Frankel and Romer (1999) argue that income grows through the exchange of ideas through communication and travel, Andersen and Dalgaard (2011); Tani and Joyeux (2013) argue that international flows of people increase productivity of the home country, Hildebrandt et al. (2005); Pfutze (2012) argue that the knowledge of health and democracy transfers through international human interaction, and Durand et al. (1996) argue that international human interaction stimulates economic activity. Le (2008) uses a pooled dataset of OECD countries and finds that highly skilled workers import R\&D from other countries. Similarly, Le (2012) uses data during the period 1998-2006 to find R\&D spillovers by highly skilled workers from industrialized countries to African countries.

Foreign education also helps developing countries to import new technologies from abroad. Import of technology is, specifically, important for developing countries to increase their productivity These countries, by sending their students abroad, can take advantage of the stock

\footnotetext{
${ }^{6}$ See Agrawal et al. (2006); Almeida and Kogut (1999); Foster and Rosenzweig (1995) for empirical evidence in favor of knowledge diffusion by personal contact.
} 
of knowledge, produced outside their national borders. The role of foreign education, in the country of origin, is explored by some authors. For example, Spilimbergo (2009) finds that the foreign educated individuals promote democracy in the country of origin. Bergerhoff et al. (2013) find international student mobility increases steady state growth rate of both the host and origin country by 0.013 percent.

\subsection{Data}

This paper uses an unbalanced annual panel data of 111 countrie: $7^{7}$ during the period 1950-2012. This section briefly describes the variables and data sources of this paper.

Total Factor Productivity: The main dependent variable of this paper, total factor productivity, is taken from Penn World Table version 8.1 (PWT 8.1) 8 PWT 8.1 reports TFP accounting for variable labor share in GDP and variable depreciation rates across countries ${ }^{9}$ PWT 8.1 data are different from earlier studies, for example, Hall and Jones (1999) and Caselli (2005) constructed TFP by assuming a constant depreciation rate across countries and over time.

Students Abroad: The main explanatory variable of this paper is the total number of tertiary level international students (university education and higher) as a share of population, denoted by 'Students Abroad'. This variable refers to students who cross national border to study outside their country of citizenship, or are enrolled in a distance learning program abroad. The data for this variable are taken from UNESCO 10 These data cover those students who are pursuing a higher education degree outside their country of residence and exclude those students who are studying abroad for less than a full school year.

These data are reported by the receiving countries, which collect these data from local education institutions. These data are available only for few countries before 1960 but covers almost all host countries and majority of home countries for the period 1960-2012. These data have some limitation (1) some countries do not specify the country of origin of the arriving

\footnotetext{
${ }^{7}$ List of countries in the appendix.

8 variable 'ctfp' in Penn World Table version 8.1.

${ }^{9}$ see Inklaar and Timmer (2013) and Feenstra et al. (2015) for a complete discussion

${ }^{10}$ UNESCO online data is available only from 2000 to 2012. The author is thankful to Antonio Spilimbergo (Spilimbergo, 2009) for sharing UNESCO data for the period 1950-2002.
} 
students. This makes the number of students from the origin country underreported (2) UNESCO do not split data according to the field of study. The contribution of a foreign educated engineer on home country technology is likely to be different than that of a history major.

Geographic Factors: Following Andersen and Dalgaard (2011), this paper uses three geographic factors to account for cross country differences in technology and productivity due to geography: a dummy variable denoted as 'Landlocked', which takes a value of 1 if the country is landlocked and 0 otherwise, fraction of land area in the tropics (\% Area in Tropics), and latitude of a country (Latitude). Data for landlocked and fraction of area in the tropics are taken from Gallup et al. (1999), and data for latitude are taken from Hall and Jones (1999).

Other Variables: This paper uses polity IV index (denoted as 'Institutions') as a measure of institution quality in the home country. Data for trade flow (imports and exports as a percentage of GDP) and FDI (percentage of GDP) are taken from World Development Indicators, and data for real per capita GDP and population are taken from Penn World Table version 8.1.

\subsection{Empirical Methodology}

\subsubsection{Partial Correlations}

Partial correlations give the first impression about the relationship between two variables. Table 2.2 reports partial correlations between the dependent variable 'TFP; and all other explanatory variables. The table shows that the correlation between TFP and student is positive. The correlation is positive between TFP and institutions, and latitude, and negative for landlocked, percent area in the tropics. This provides the first evidence that foreign education promotes the process of technology diffusion across countries. 


\subsubsection{Model}

This paper employs a simple model to analyze the relationship between foreign education and technology diffusion.

$$
\ln \left(\text { TFP }_{i t}\right)=\beta_{0}+\beta_{1} \ln \left(\text { Students }_{i, t-5}\right)+\beta_{2} X_{i t}+v_{i t}
$$

Here the primary variable of interest is Students $_{i, t}$. The dependent variable of this paper is total factor productivity, $\ln (T F P) . \quad X_{i t}$ is the vector of control variables and includes the percentage area of a country in the tropical zone (\% Area in Tropics), latitude of home country (Latitude), polity IV index (Institutions), total trade flow of country (Trade), foreign direct investment (FDI), and landlocked dummy variable indicating 1 if the country is landlocked and 0 otherwise (Landlocked).

This paper analyzes the impact of foreign education on technology diffusion in three time periods: the short run (5-year lag), the medium run (10-year lag), and the long run (20year lag). These lags capture the idea, that students need to graduate and return to their home countries before they disperse the knowledge that they acquired in the foreign country. These lags also reveal the long run effects of foreign education on technology diffusion in home country.

\subsubsection{Bilateral Equation Estimation}

Foreign education is likely to be endogenous in the above model as high TFP (advanced) countries may exchange more foreign students than low TFP (developing) countries. Some unobserved factors may also affect foreign education as well as technology diffusion. For example, Spilimbergo (2009), Kim (1998), and Barnett and Wu (1995) argue that foreign education is motivated by geographic factors and bilateral links. This implies that countries close to each other may exchange more students and hence transfer more technologies between them. Geographic factors are also correlated with technology diffusion (Diamond, 1999; Gallup et al., 1999; Andersen and Dalgaard, 2011).

This paper deals with this endogeniety problem by an instrumental variable method. In the first stage, this paper follows Spilimbergo (2009) strategy and uses population of home 
country, population of host country, and the popularity of the host country to instrument for student. Variable popularity is calculated as the total number of international students in host country excluding students from the home country. The popularity of the host country among international students may depend on the availability of scholarships, ease to get into the host country, and other factors. This variable is a good instrument for foreign education as it satisfies the exclusion restriction. It explains the choice of destination country but does not affect technology level in home country. This paper, therefore, estimates below bilateral gravity equation.

$$
\text { Students }_{i j, t}=a^{\prime} Z_{i j, t}+\delta_{i j, t}
$$

Where $Z_{i j, t}$ is the set of regressors including home country population, host country population, and the populatrity of the host country among international students. Specifically, this paper estimates the following bilateral equation:

$$
\ln \left(\text { Students }_{i j, t}\right)=\alpha_{0}+\alpha_{1} \ln \left(\text { Pop }_{i, t}\right)+\alpha_{2} \ln \left(\text { Pop }_{j, t}\right)+\alpha_{3} \ln \left(\text { Popularity }_{j t}\right)+\epsilon_{i j}
$$

Where $P o p_{i}$ is the population size of home country, $P o p_{j}$ is the population size of host country, and Popularity $j \mathrm{i}$ is the total number of students in host country excluding students from home country. In the first stage, this paper uses the above gravity equation and predicts foreign students flow. These predicted values are then summed up to find fitted foreign education values as follows.

$$
(\widehat{\text { Students }})_{i t}=\sum_{j \neq i} e^{\widehat{a}^{\prime} Z_{i j, t}}
$$

In the second stage, above fitted values from equation 2.4 are used as an instrument for Student variable in equation 2.1.

The bilateral foreign education equation results are presented in table 2.3 in the appendix. Column 1 represents pooled OLS regression results without including any fixed and time effects. This model explains about 45 percent of the variation in the bilateral student flows. Home country population size has a negative and host country population size has a positive effect on the students flows from country $i$ to country $j$. The elasticity of bilateral student flows with respect to home and host country population is 0.64 and 0.13 , respectively. This 
shows that 10 percent increase in the host and the home country population is associated 1.3 percent increase in the inflows of students for the host country and 6.4 percent decrease in the outflows of students from the host country. As expected, some countries are more popular among international students than other countries, as shown by the positive and statistically significant coefficient for popularity. Students are 60 percent more likely to choose the destination country which other students are choosing.

Column 2 reports fixed effects estimates and include both time and fixed effect in the model. This model explains about 45 percent of the variation in the dependent variable. The elasticity of bilateral student flows with respect to home country population, host country population, and the popularity of host country is $0.63,0.09$, and 0.65 respectively. Where the first two elasticities are lower while elasticity of popularity of host country is about 8 percent greater than pooled OLS model. This paper uses pooled OLS model to predict bilateral student flows variable.

\subsubsection{SLS Estimation}

Table 2.4 in the appendix presents $\ln (\mathrm{TFP})$ as a dependent variable. Column 1 reports pooled OLS estimate for $\ln (\mathrm{TFP})$ as a dependent variable and only main explanatory variable, student abroad, on the right hand side. Students abroad has a positive and statistically significant coefficient value. TFP has an elasticity of 0.01 with respect to student abroad. The results does not change much in the fixed effects settings in column 2 , while the coefficient value stays the same, standard error decreases by 60 percent in the fixed effects settings. Column 3 reports two-stage least squares estimate for student abroad and column 4-7 include additional control variables. In two-stage least squares settings students abroad has a positive and statistically significant coefficient value. The elasticity of TFP with respect to student abroad increases from 0.014, in OLS setting, to 0.065 in the two-stage least squares setting. This indicates that reverse causality is not a big issue in the model. This also shows that an increase in the student abroad by 10 percent is associated with an increase in the TFP by 0.6 percent. The coefficient for student abroad remains positive and statistically significant after the inclusion of other control variables in column 4-7. 


\section{Other Control Variables:}

Institution quality index, in column 4 has a positive and statistically significant coefficient, depicting the critical role of institutions in the diffusion of technologies. Geographic factors in column 5 have their expected causal effect on technology diffusion. Landlocked and percent area in tropics has a negative while latitude has a positive effect on technology diffusion. Column 6 and 7 include foreign direct investment (percent of GDP) and total trade (percent of GDP) as control variables in the model, respectively. FDI has a statistically insignificant while trade has positive and statistically significant effect on technology diffusion.

\section{Robustness Tests:}

Table 2.5 reports 2SLS estimates for $\ln (\mathrm{TFP})$ as dependent variables and compares results in the short run, medium run and the long run. Here short run, medium run, and long run imply that the main explanatory variable, student abroad, is lagged 5-year, 10-year, and 20year, respectively. Student abroad has a positive and statistically significant coefficient in the short, medium, and long run. The coefficient values for other control variables are relatively stable. Table 2.6 presents 2SLS estimates for $\ln (\mathrm{TFP})$ as dependent variables and compares results during three time periods: over all sample (1950-2012), after 1985 (1984-2012), and before 1985 (1950-1985) 11 Students abroad variable has positive and statistically significant coefficient for all sample period. All other variables show stable and expected coefficients. Moreover, system GMM result: ${ }^{12}$ further confirm the robustness of the results.

\subsection{Conclusion}

Many developing countries invest significant public and private resources on foreign education. While individual spendings on foreign education are motivated by the economic and social returns, public spending, specifically, aims to import technological knowledge from abroad. This paper tests whether the investment in foreign education has any significant

\footnotetext{
${ }^{11}$ The choice of 1985 is arbitrary.

${ }^{12}$ Results are available upon request.
} 
effect on technology diffusion. To analyze the effects of foreign education on technology diffusion, this paper uses an instrumental variable method and an unbalanced data of 111 countries between the period 1950-2012. The results show that foreign education has a positive and statistically strong positive effect on total factor productivity. The effects of foreign education are robust to the inclusion of other channels of international technology diffusion and remain for a long period of time.

The policy makers in developing countries can draw some important policy recommendations from this paper. They can allocate more public resources for foreign education to provide more scholarships for study abroad programs, and to attract foreign qualified individuals by providing more research funding, fellowships, grants, and other opportunities in home country. Developing countries can also promote foreign education by following a friendly foreign policy to start soft visa programs to facilitate international student mobility. This can reduce the student visa refusal rate.

Other countries impose visa barriers to student (1) due to security, (2) due to the fear that foreigners may harm their culture, and (3) students will not leave their country after graduating and steal their jobs. A good foreign policy is essential to cope with (1) and (2) but a good visa facilitation program is required for number (3). One such program includes J1 visa program by the U.S. government. The U.S. government gives J1 visa to foreign students and scholars to study in the US on the condition that they will go back to their home country and serve in their home country not less than the period they spent in the US. Developing countries can start this type of visa programs with other developed countries to ensure that their student will come back. 


\subsection{Appendix}

Figure 2.1: Total Number of International Tertiary Level Students

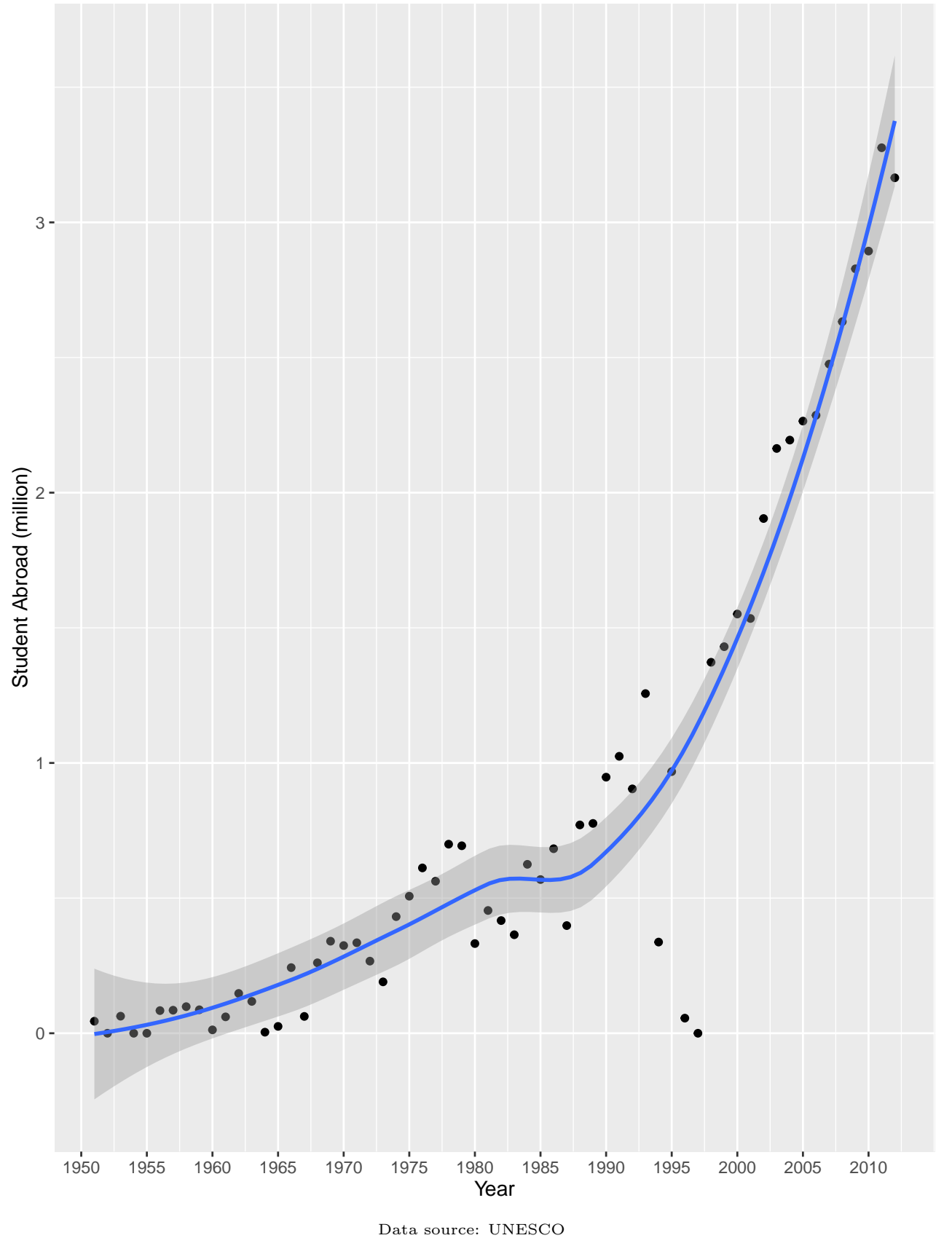


Figure 2.2: Top Ten Origin Countries for International Students (thousands)

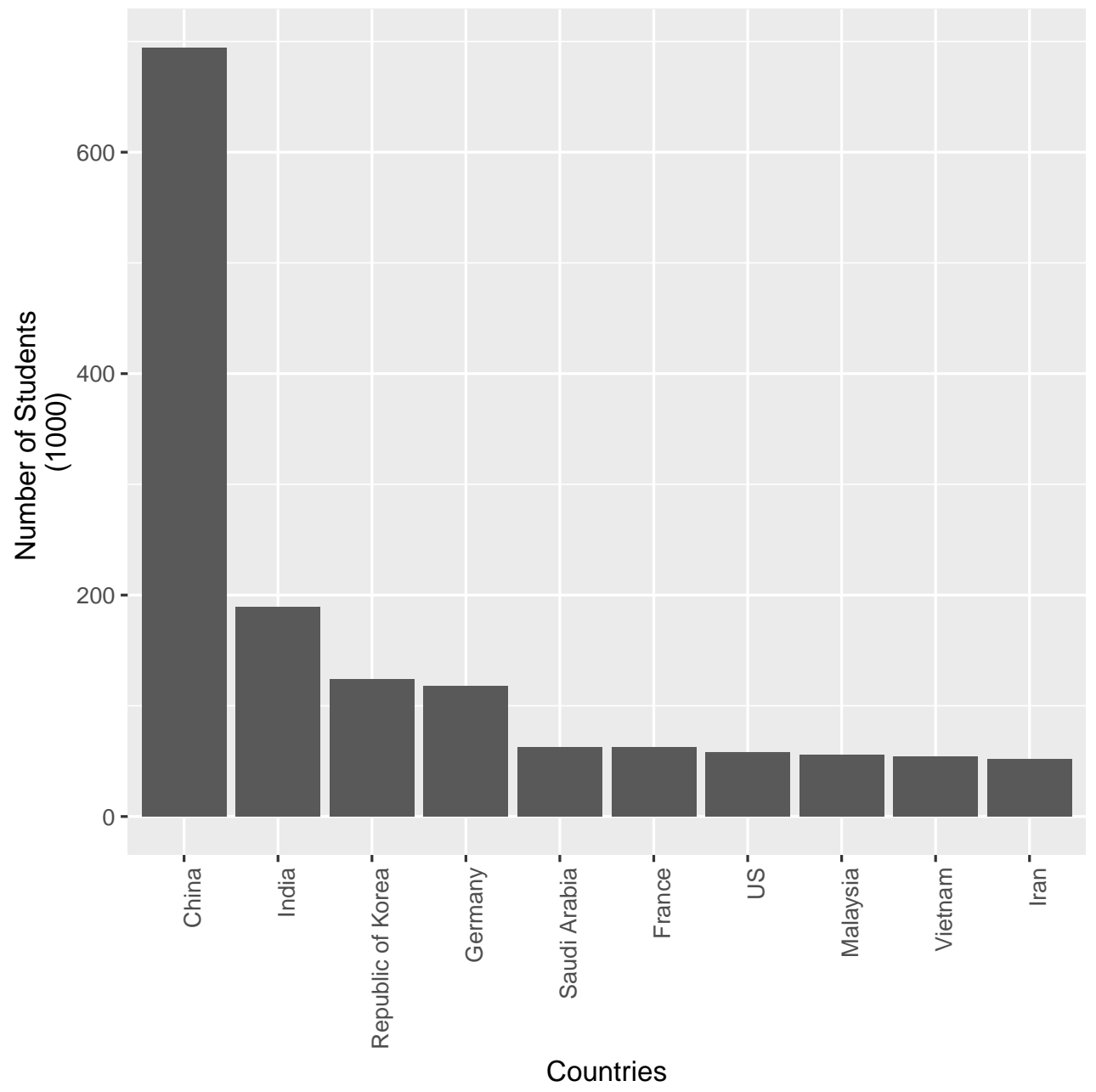

Data source: UNESCO 
Figure 2.3: Top Ten Destination Countries for International Students

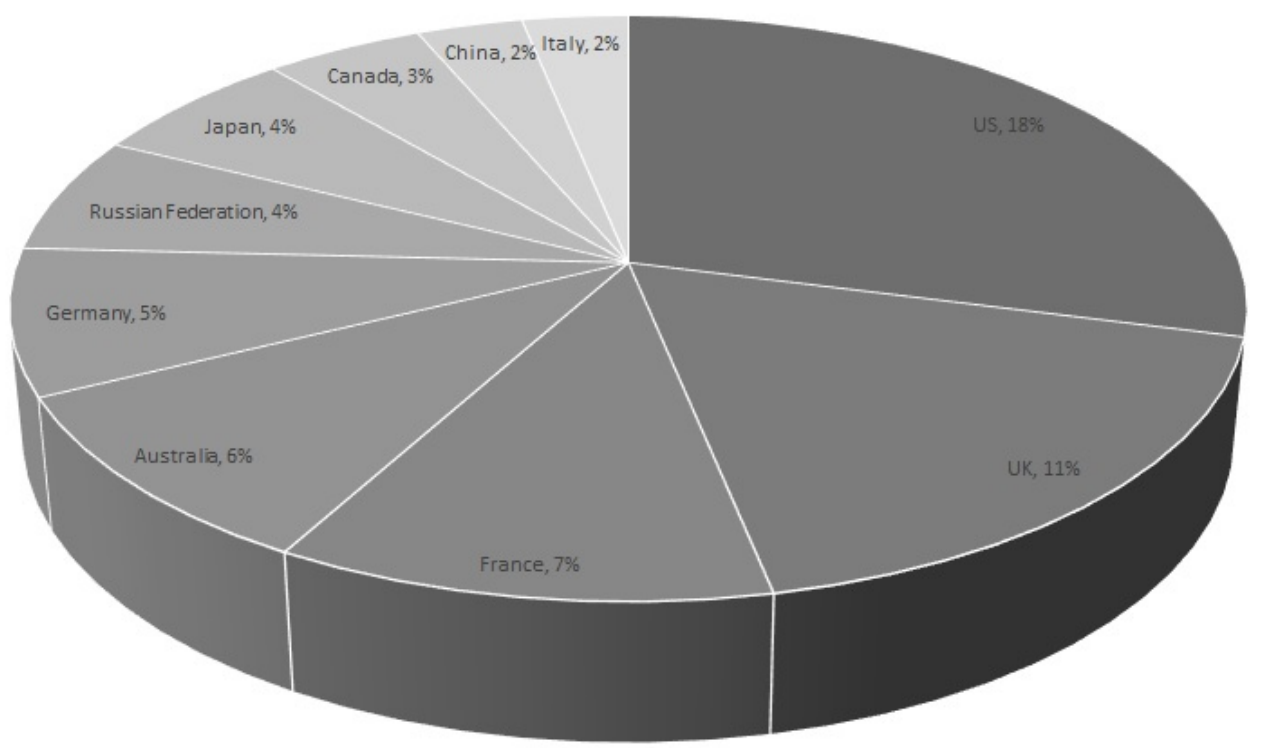

Data source: UNESCO 
Table 2.1: Descriptive Statistics

\begin{tabular}{lccccc}
\hline \hline Statistic & $\mathrm{N}$ & Mean & St. Dev. & Min & Max \\
\hline $\ln (\mathrm{TFP})$ & 4750 & -0.45 & 0.52 & -2.38 & 2.00 \\
$\ln ($ GDP per capita) & 7100 & 8.48 & 1.24 & 5.22 & 11.97 \\
$\ln ($ Student Abroad) & 7100 & 5.39 & 1.96 & -6.55 & 10.42 \\
$\ln ($ Student Abroad Fitted) & 7086 & 6.18 & 2.27 & -6.95 & 13.96 \\
Institutions & 7395 & 0.54 & 0.37 & 0.00 & 1.00 \\
Landlocked & 8400 & 0.18 & 0.38 & 0 & 1 \\
\% Area in Tropics & 7213 & 0.33 & 0.41 & 0.00 & 1.00 \\
Latitude & 7120 & 15.75 & 24.26 & -36.89 & 63.89 \\
FDI & 5562 & 3.17 & 7.46 & -82.89 & 173.45 \\
Trade & 6698 & 75.71 & 48.92 & 0.02 & 531.74 \\
\hline \hline
\end{tabular}


Table 2.2: Correlation Matrix

\begin{tabular}{llllllllllll}
\hline \hline TFP & 1 & & & & & & & & \\
GDP p.c. & 0.59 & 1 & & & & & & & & \\
Students & 0.15 & 0.25 & 1 & & & & & & & \\
Students (fitted) & 0.14 & 0.23 & 0.64 & 1 & & & & & & \\
Institutions & 0.21 & 0.44 & 0.13 & 0.12 & 1 & & & & & \\
Landlocked & -0.2 & -0.17 & 0 & -0.01 & -0.05 & 1 & & & & \\
\% Area in Tropics & -0.32 & -0.38 & -0.21 & -0.2 & -0.2 & -0.06 & 1 & & & \\
Latitude & 0.29 & 0.34 & 0.19 & 0.18 & 0.28 & -0.14 & -0.37 & 1 & & \\
FDI & -0.02 & 0.09 & 0.19 & 0.17 & 0.15 & 0.02 & 0.02 & -0.01 & 1 & \\
Trade & 0.03 & 0.08 & 0.38 & 0.29 & 0.01 & 0.12 & -0.05 & 0.08 & 0.27 & 1 \\
\hline \hline
\end{tabular}


Table 2.3: Bilateral Foreign Education Equation

\begin{tabular}{lcc}
\hline & $\ln ($ Bilateral Flow of Students $)$ \\
& Pooled & Fixed \\
\hline $\ln (\text { Home Country Population })_{i t}$ & $-0.640^{* * *}$ & $-0.631^{* * *}$ \\
& $(0.003)$ & $(0.003)$ \\
$\ln (\text { Destination Country Population })_{j t}$ & $0.134^{* * *}$ & $0.086^{* * *}$ \\
& $(0.004)$ & $(0.005)$ \\
$\ln (\text { Popularity of Host Country })_{i, j t}$ & $0.599^{* * *}$ & $0.648^{* * *}$ \\
& $(0.004)$ & $(0.004)$ \\
Constant & $-3.818^{* * *}$ & \\
& $(0.034)$ & \\
\hline Time effects? & No & Yes \\
Home country effects? & No & Yes \\
Host country effects? & No & Yes \\
\hline N & 125747 & 125747 \\
R-squared & 0.45 & 0.45 \\
\hline
\end{tabular}

Notes: $* * * \mathrm{p}<.01 ;{ }^{* *} \mathrm{p}<.05 ;{ }^{*} \mathrm{p}<.1$. Robust standard errors in parentheses.

The sample is an unbalanced panel comprising annual data between 1950-2012. 
Table 2.4: Dependent Variable: $\ln (\mathrm{TFP})$

\begin{tabular}{|c|c|c|c|c|c|c|c|}
\hline & (1) & (2) & (3) & (4) & (5) & (6) & (7) \\
\hline VARIABLES & OLS & $\mathrm{FE}$ & TSLS & TSLS & TSLS & TSLS & TSLS \\
\hline $\ln (\text { Student Abroad })_{i t-5}$ & $\begin{array}{c}0.014^{* * *} \\
(0.005)\end{array}$ & $\begin{array}{c}0.014^{* * *} \\
(0.002)\end{array}$ & $\begin{array}{c}0.065^{* * *} \\
(0.004)\end{array}$ & $\begin{array}{c}0.056^{* * *} \\
(0.005)\end{array}$ & $\begin{array}{c}0.044^{* * *} \\
(0.004)\end{array}$ & $\begin{array}{c}0.050^{* * *} \\
(0.007)\end{array}$ & $\begin{array}{c}0.026^{* * *} \\
(0.006)\end{array}$ \\
\hline Institutions $_{i t-5}$ & & & & $\begin{array}{c}0.224^{* * *} \\
(0.021)\end{array}$ & $\begin{array}{c}0.148^{* * *} \\
(0.019)\end{array}$ & $\begin{array}{c}0.069 * * * \\
(0.024)\end{array}$ & $\begin{array}{c}0.146^{* * *} \\
(0.021)\end{array}$ \\
\hline Landlocked & & & & & $\begin{array}{c}-0.345^{* * *} \\
(0.021)\end{array}$ & $\begin{array}{c}-0.400 * * * \\
(0.026)\end{array}$ & $\begin{array}{c}-0.420^{* * *} \\
(0.024)\end{array}$ \\
\hline$\%$ Area in Tropics & & & & & $\begin{array}{c}-0.364^{* * *} \\
(0.020)\end{array}$ & $\begin{array}{c}-0.427 * * * \\
(0.024)\end{array}$ & $\begin{array}{c}-0.380 * * * \\
(0.021)\end{array}$ \\
\hline Latitude & & & & & $\begin{array}{c}0.002^{* * *} \\
(0.000)\end{array}$ & $\begin{array}{c}0.003^{* * *} \\
(0.000)\end{array}$ & $\begin{array}{c}0.003^{* * *} \\
(0.000)\end{array}$ \\
\hline $\mathrm{FDI}_{i t-5}$ & & & & & & $\begin{array}{l}-0.002 \\
(0.003)\end{array}$ & \\
\hline $\ln \left(\operatorname{Trade}_{i t-5}\right)$ & & & & & & & $\begin{array}{c}0.001^{* * *} \\
(0.000)\end{array}$ \\
\hline Constant & $\begin{array}{c}-0.587^{* * *} \\
(0.056)\end{array}$ & $\begin{array}{c}-0.523^{* * *} \\
(0.012)\end{array}$ & $\begin{array}{c}-0.788^{* * *} \\
(0.024)\end{array}$ & $\begin{array}{c}-0.891^{* * *} \\
(0.027)\end{array}$ & $\begin{array}{c}-0.645^{* * *} \\
(0.027)\end{array}$ & $\begin{array}{c}-0.638^{* * *} \\
(0.044)\end{array}$ & $\begin{array}{c}-0.623^{* * *} \\
(0.030)\end{array}$ \\
\hline Observations & 4,190 & 4,190 & 4,189 & 3,995 & 3,523 & 2,474 & 3,068 \\
\hline R-squared & 0.056 & 0.010 & 0.056 & 0.073 & 0.249 & 0.302 & 0.287 \\
\hline Time effects? & No & No & Yes & Yes & Yes & Yes & Yes \\
\hline Country Effects? & No & Yes & Yes & Yes & Yes & Yes & Yes \\
\hline
\end{tabular}

Notes: $* * * \mathrm{p}<.01 ;{ }^{* *} \mathrm{p}<.05 ;{ }^{*} \mathrm{p}<.1$. Robust standard errors in parentheses. The sample is an unbalanced panel comprising annual data between 1950-2012. OLS estimates in column 1, fixed effects in column 2, and 2SLS in column 3-7. The dependent variable is $\ln (\mathrm{TFP})$. 
Table 2.5: Medium Run and Long Run (Pooled 2SLS)

\begin{tabular}{|c|c|c|c|}
\hline \multirow[b]{3}{*}{ VARIABLES } & \multicolumn{3}{|c|}{$\ln (\mathrm{TFP})$} \\
\hline & $(1)$ & $(2)$ & $(3)$ \\
\hline & Short-run & Medium-run & Long-run \\
\hline \multirow[t]{2}{*}{$\ln (\text { Student Abroad })_{i t-5}$} & $0.044^{* * *}$ & & \\
\hline & $(0.004)$ & & \\
\hline \multirow[t]{2}{*}{$\ln (\text { Student Abroad })_{i t-10}$} & & $0.035^{* * *}$ & \\
\hline & & $(0.005)$ & \\
\hline \multirow[t]{2}{*}{$\ln \left(\right.$ Student Abroad $_{i t-20}$} & & & $0.029^{* * *}$ \\
\hline & & & $(0.005)$ \\
\hline \multirow[t]{2}{*}{ Institutions $_{i t-5}$} & $0.148^{* * *}$ & & \\
\hline & $(0.019)$ & & \\
\hline \multirow[t]{2}{*}{ Institutions $_{i t-10}$} & & $0.247^{* * *}$ & \\
\hline & & $(0.019)$ & \\
\hline \multirow[t]{2}{*}{ Institutions $_{i t-20}$} & & & $0.374^{* * *}$ \\
\hline & & & $(0.021)$ \\
\hline \multirow[t]{2}{*}{ Landlocked } & $-0.345^{* * *}$ & $-0.329 * * *$ & $-0.328 * * *$ \\
\hline & $(0.021)$ & $(0.021)$ & $(0.022)$ \\
\hline \multirow[t]{2}{*}{$\%$ Area in Tropics } & $-0.364^{* * *}$ & $-0.362^{* * *}$ & $-0.374^{* * *}$ \\
\hline & $(0.020)$ & $(0.020)$ & $(0.021)$ \\
\hline \multirow[t]{2}{*}{ Latitude } & $0.002^{* * *}$ & $0.002^{* * *}$ & $0.002^{* * *}$ \\
\hline & $(0.000)$ & $(0.000)$ & $(0.000)$ \\
\hline \multirow[t]{2}{*}{ Constant } & $-0.645^{* * *}$ & $-0.656^{* * *}$ & $-0.700^{* * *}$ \\
\hline & $(0.027)$ & $(0.027)$ & $(0.028)$ \\
\hline Observations & 3,523 & 3,231 & 2,568 \\
\hline R-squared & 0.249 & 0.276 & 0.347 \\
\hline Time effects? & Yes & Yes & Yes \\
\hline Country Effects? & Yes & Yes & Yes \\
\hline
\end{tabular}

Notes: $* * * \mathrm{p}<.01 ;{ }^{* *} \mathrm{p}<.05 ;{ }^{*} \mathrm{p}<.1$. Robust standard errors in parentheses. The sample is an unbalanced panel comprising annual data between 1950-2012. Two-stage least squares estimates. The dependent variable is $\ln (\mathrm{TFP})$. 
Table 2.6: Time Period (cut-off 1985)

VARIABLES

$\ln (\mathrm{TFP})$

(1)

(2)

(3)

Over-all sample After 1985 Before 1985

$(1950-2012) \quad(1985-2012) \quad(1950-1985)$

$\begin{array}{lccc}\ln (\text { Student Abroad })_{i t-5} & 0.044^{* * *} & 0.057^{* * *} & 0.059^{* * *} \\ & (0.004) & (0.007) & (0.006) \\ & 0.148^{* * *} & 0.234^{* * *} & 0.143^{* * *} \\ \text { Institutions }_{i t-5} & (0.019) & (0.027) & (0.027) \\ & -0.345^{* * *} & -0.360^{* * *} & -0.237^{* * *} \\ \text { Landlocked } & (0.021) & (0.026) & (0.033) \\ & -0.364^{* * *} & -0.415^{* * *} & -0.274^{* * *} \\ \text { \% Area in Tropics } & (0.020) & (0.026) & (0.029) \\ & 0.002^{* * *} & 0.003^{* * *} & 0.001^{*} \\ \text { Latitude } & (0.000) & (0.000) & (0.000) \\ & -0.645^{* * *} & -0.867^{* * *} & -0.590^{* * *} \\ \text { Constant } & (0.027) & (0.043) & (0.034)\end{array}$

\begin{tabular}{lccc}
\hline Observations & 3,523 & 1,944 & 1,498 \\
R-squared & 0.249 & 0.349 & 0.185 \\
\hline Time effects? & Yes & Yes & Yes \\
Country Effects? & Yes & Yes & Yes \\
\hline
\end{tabular}

Notes: $* * * \mathrm{p}<.01 ;{ }^{* *} \mathrm{p}<.05 ;{ }^{*} \mathrm{p}<.1$. Robust standard errors in parentheses.

The sample is an unbalanced panel comprising annual data between 19502012. Two-stage least squares estimates. The dependent variable is $\ln (\mathrm{TFP})$. 
Table 2.7: List of Countries in the Sample

\begin{tabular}{|c|c|c|c|}
\hline Argentina & Estonia & Lesotho & Saudi Arabia \\
\hline Armenia & Fiji & Lithuania & Senegal \\
\hline Australia & Finland & Luxembourg & Serbia \\
\hline Austria & France & Macao & Sierra Leone \\
\hline Bahrain & Gabon & Malaysia & Singapore \\
\hline Barbados & Germany & Malta & Slovakia \\
\hline Belgium & Greece & Mauritania & Slovenia \\
\hline Benin & Guatemala & Mauritius & South Africa \\
\hline Bolivia & Honduras & Mexico & Spain \\
\hline Botswana & Hong Kong & Moldova & Sri Lanka \\
\hline Brazil & Hungary & Mongolia & Swaziland \\
\hline Bulgaria & Iceland & Morocco & Sweden \\
\hline Burundi & India & Mozambique & Switzerland \\
\hline Cameroon & Indonesia & Namibia & Taiwan \\
\hline Canada & Iran & Netherlands & Tajikistan \\
\hline Central African Republic & Iraq & New Zealand & Tanzania \\
\hline Chile & Ireland & Niger & Thailand \\
\hline China & Israel & Norway & Togo \\
\hline Colombia & Italy & Panama & Trinidad And Tobago \\
\hline Costa Rica & Jamaica & Paraguay & Tunisia \\
\hline Cote D'Ivoire & Japan & Peru & Turkey \\
\hline Croatia & Jordan & Philippines & Ukraine \\
\hline Cyprus & Kazakhstan & Poland & United Kingdom \\
\hline Czech Republic & Kenya & Portugal & United States \\
\hline Denmark & Korea & Qatar & Uruguay \\
\hline Dominican Republic & Kuwait & Romania & Venezuela \\
\hline Ecuador & Kyrgyzstan & Russian Federation & Zimbabwe \\
\hline Egypt & Latvia & Rwanda & \\
\hline
\end{tabular}




\section{Chapter 3}

\section{Barriers to International Mobility and Technology Diffusion}

Barriers to international mobility are the critical factors to impede the process of international technology diffusion. Using bilateral visa restrictions data from 30 host and 198 home countries over the period of 2001-2012, this paper shows that the international technology gap increases as the barriers to international mobility increase. These results are robust across three different measures of visa restrictions and even after taking care of econometric problem of endogeneity. The results suggest that visa facilitation programs by advanced countries could promote international technology diffusion.

\subsection{Introduction}

There remain significant differences in total factor productivity (TFP) across countries ${ }^{1}$ Some researchers believe that productivity differs across countries because of the slow process of international technology diffusion 2 This paper follows the previous research and assumes that technologies diffuse across countries when societies interact with other societies $3^{3}$ This exposure helps societies to adopt advanced technologies and new ideas prevailing in a foreign space.

\footnotetext{
${ }^{1}$ see Caselli (2005), Klenow and Rodriguez-Clare (1997), and Hall and Jones (1999)

${ }^{2}$ see Howitt (2000) and Klenow and Rodriguez-Clare (2005)

${ }^{3}$ see for example Keller (2004)
} 
However, not all societies enjoy an equal exposure to foreign space, which depends on the citizenship of the travelers and their destination countries. The U.S. citizens, for example, have visa free access to 155 countries, whereas Pakistani citizens have visa free access to 27 countries $4^{4}$ More passport power gives its holder easy access to more foreign space, to a larger stock of knowledge, and to superior technologies abroad. On the other hand, barriers to international mobility reduce the exchange of tourists, businessmen, and students across countries. Which slows down the process of international technology diffusion.

This paper sheds light on the slow process of international technology diffusion and advances the existing literature in the following ways. First, this paper analyzes the effects of barriers to international mobility on technology diffusion across countries, a topic not investigated heavily in economic literature. Most of the earlier research analyzes the effects of barriers to mobility on cross-country tourism and international trade.5 Second, this paper features bilateral TFP gap as the dependent variable, calculated as the absolute difference between the TFP of the home and the host country, which helps to further explore the effects of bilateral factors, such as geographical distance and common spoken language, on the bilateral TFP gap.

Third, earlier research uses a dummy variable as a measure of international barriers to mobility, which indicates whether a visa is required to enter a country or not; whereas, this paper uses visa refusal rate as the main measure of barriers to international mobility. The visa refusal rate is calculated as the number of visas refused divided by the total number of applications received. To check the robustness of the results, two additional measures of barriers to mobility, visa restriction index and visa requirement index, are also used. The data for visa refusal rate, visa restriction index, and visa requirement index are taken from Hobolth (2012).

Visa refusal rate, compared to the other two measures of barriers to mobility, shows the intensity of barriers to mobility from the home to the host country. For example, if

\footnotetext{
${ }^{4}$ see www.passportindex.org for the latest ranking of passports and Lawson and Lemke (2012) for a nice exposition to the political economy of visa restrictions.

${ }^{5}$ For example, Neumayer (2010) finds that visa requirements decrease business travel and tourism. Neumayer (2011) also finds that visa requirements reduce bilateral trade and foreign direct investment. Similarly, Lawson and Roychoudhury (2013) estimate that visa requirements reduce inbound travel.
} 
the citizens of two countries need a visa to travel to a host country, the citizens of the first country may get a visa very easily while excessive paperwork may be required for the citizens of the second country, where the majority of the visas are denied. Thus, the barriers to mobility will be higher for the second country. The second measure of barriers to mobility is visa restriction index, which encompasses three dimensions of barriers to mobility: (1) whether citizens of the home country need a visa to enter the host country, (2) the intensity of visa restrictions, and (3) whether a visa application can be submitted in the country of origin or not. Hobolth (2012) constructs this index on a scale that ranges from 0 to 3 , to simplify the results this paper merges and uses only two categories: no barriers to mobility and barriers to mobility. Visa requirement index, the third measure of barriers to mobility, is a dummy variable and indicates whether citizens of the home country need a visa to enter the host country.

To investigate the association between barriers to international mobility and technology diffusion, this paper uses bilateral data of 30 host OECD and 198 home countries over the period of 2001-2012. Empirically, the visa refusal rate may be endogenous with the TFP gap. A low TFP home (developing) country may face high barriers to mobility from high TFP host (advanced) countries. In this case, we may have a reverse causality issue. The advanced countries may impose high barriers to mobility on the citizens of the developing country to stop illegal immigration. To address this issue, this paper uses genetic distance as an instrumental variable for visa refusal rate. Genetic distance is the probability that two randomly selected individuals from two populations will be different. The genetic distance between two populations is zero if and only if the two populations are identical 6 The data for genetic distance are taken from Spolaore and Wacziarg (2009). The underlying assumption is that genetic dissimilarity (a larger genetic distance between two populations) increases mistrust between population: $\mathrm{7}^{7}$ and, hence, increases barriers to international mobility. A further concern is that current genetic distance may be correlated with the TFP gap. This may be due to the factors such as migration. For example, European colonizers settled in

\footnotetext{
${ }^{6}$ see Spolaore and Wacziarg (2009) for a complete exposition to genetic distance and its effect on barriers to technology transfer.

7 see for example Guiso et al. (2009).
} 
the regions suitable to them. This migration pattern may explain not only the TFP gap but also the genetic distance between populations today. This paper, therefore, uses genetic distance in 1500 as an instrumental variable for current genetic distance. Because, genetic distance in 1500 is from the period prior to industrial revolution and great migration, we can argue that genetic distance in 1500 does not affect bilateral TFP gap today.

This paper estimates the causal relationship between barriers to international mobility and bilateral TFP gap using different estimation methods: panel OLS, 2SLS, 3SLS, and logit model. In panel OLS settings, the bilateral TFP gap shows an elasticity of 0.04 percent with respect to the visa refusal rate, while this elasticity is 0.54 and 0.38 in 2SLS and 3SLS settings, respectively. The average visa refusal rate in the sample is about 12 percent. The average visa refusal rate, for top 20 most restricted countries, is about 40 percent. This indicates that the TFP gap is increasing in the range of 15-21 percent for these countries.

The other two additional measures of barriers to mobility, visa restriction index and visa requirement index, show the same results. The visa restriction index shows that if the partner country imposes barriers to mobility on the citizens of the home country, the TFP gap between the country pair increases by about 0.08 percent. The visa requirement index indicates that if the partner country changes its policy from a visa free to a visa required country, the TFP gap between the country pair increases by about 0.08 percent.

To further test the robustness of the results this paper converts the dependent variable, TFP gap, into a dummy variable. This dummy variable shows whether TFP gap between a country pair exists. This specification is then estimated using the logit model. The results indicate that if the visa refusal rate increases by 1 percent, there is 12 percent more chance that the home country has lower productivity relative to the partner country. This paper, hence, sheds light on the slow diffusion of international technologies by arguing that barriers to international mobility hinder international technology diffusion.

This paper is related to the economic literature, which has explored the effects of human interaction on technology diffusion (Lucas, 1988; Irwin and Klenow, 1994; Foster and Rosenzweig, 1995; Almeida and Kogut, 1999; Agrawal et al., 2006; Andersen and Dalgaard, 2011; Tani and Joyeux, 2013; Hovhannisyan and Keller, 2015). However, this paper is different from the above as it tests the flip-side of the Andersen and Dalgaard (2011) and Tani and 
Joyeux (2013) argument; what are the effects of barriers to international human interaction (international mobility) on technology diffusion?

This paper is also related to the economic literature, which investigates the effects of barriers to mobility on international trade, foreign direct investment, and tourism. For example, Neumayer (2010) finds that visa requirements decrease business travel and tourism. Neumayer (2011) also finds that visa requirements reduce bilateral trade and foreign direct investment. Similarly, Lawson and Roychoudhury (2013) estimate that visa requirements reduce inbound travel. However, the effects of international barriers to mobility on international technology diffusion are not explored in this literature, and this paper fills this gap.

The rest of the paper is organized as follows: Section 3.2 explores the channels through which barriers to mobility could affect technology diffusion; Section 3.3 discusses the trends in international travel and barriers to mobility; Section 3.4 presents a brief history of passports and visas; Section 3.5 describes the data; Section 3.6 presents empirical methodology and results; and Section 3.7 concludes.

\subsection{How Do Barriers to Mobility Affect International Technology Diffusion?}

This section explores different types of barriers to mobility that international travelers face, and then explores the link between barriers to mobility and international technology diffusion. International travelers face barriers to mobility in different forms, either in the form of requiring a visa before the physical entry into a host country, or in the form of a high visa rejection rate. 8 Most international travelers require a valid visa before entering a foreign space. A visa is defined as a "document issued in the country of origin (or residence) of the individual by the authorities of the state to which he or she wishes to go" (Guild, 2009). National states have always had the monopoly over who can enter or exit their national

\footnotetext{
${ }^{8}$ For natural barriers to international mobility, for example geography, see Gallup et al. (1999) and Diamond (1999).
} 
borders. Most democratic states use this monopoly for economic and political reasons $9^{9}$ and exercise exit control only for a few cases ${ }^{10}$ Autocratic and repressive regimes, on the other hand, may use this monopoly, specifically, for political reasons: to prevent entry and exit of their opponents and ordinary citizens ${ }^{11}$ These regimes may use this monopoly to subsidize the political threats and extend their own political power (La Porta et al., 1999). This paper, however, ignores the exit control and discusses the more ubiquitous case: controlling and restricting the foreigners to enter in the national borders.

Barriers to mobility can also take the form of a high visa refusal rate; a state can refuse to share its space with a foreigner. In 2015, the U.S. refused 3.1 million non-immigrant visas. ${ }^{12}$ a visa refusal rate of about 22 percent. Among these were 0.25 million student visas ${ }^{13}$ and 2.2 million business visas. The average visa refusal rate in the sample is about 12 percent. The average visa refusal rate for top 20 most restricted home countries is about 40 percent, with Somalia having average visa refusal rate of about 60 percent. Each visa refusal represents a missed learning or business opportunity for these countries and disconnects them from the rest of the world, consequently hindering the personal interaction and technology transfer towards the home countries.

How do barriers to mobility affect technology diffusion across countries? Barriers to mobility impede human interaction, which is a key source to diffuse international technologies. ${ }^{14}$ Human interaction is required to transmit a part of knowledge that cannot be codified. Research shows that human interaction increases the chance of doing business and promotes international trade ${ }^{15}$ Frankel and Romer (1999) associate greater human interaction with more international trade ${ }^{16}$ Barriers to mobility, on the other hand, impede business travel

\footnotetext{
${ }^{9}$ see Lawson and Lemke (2012) for an exposition to the political economy of visas.

${ }^{10}$ For example, to prevent high profile criminals to flee from the country during the trial.

${ }^{11}$ The East Germany, in recent history, is an extreme example of exit control by a repressive regime.

12 https://travel.state.gov

${ }^{13}$ Student visas include visa applications in the category of F1 and J1

${ }^{14}$ see, for example, Lucas (1988) and Irwin and Klenow (1994) provide the same notion. See Foster and Rosenzweig (1995), Almeida and Kogut (1999), and Agrawal et al. (2006) for empirical evidence in favor of knowledge diffusion by personal contact.

${ }^{15}$ For example, Cristea (2011) argues that personal human interaction promotes international trade and Oxford Economics (2012) argues that human interaction improves the chances of doing business with foreigners.

${ }^{16}$ Transfer of technology via international trade has been extensively studied in the economic literature, see for example, Engelbrecht (1997), Keller (1998), Edmond (2001), and Lee (2006)
} 
and subsequently prevent technologies to diffuse across countries.

Business trips increase human interaction with foreigners and help firms to obtain knowledge about international technologies, learn new ideas, and organizational strategies from their partner, which can increase their productivity. Tani and Joyeux (2013) argue that businessmen are highly educated individuals and international business trips help them access the knowledge produced somewhere else. Similarly, Dowrick and Tani (2011) associate international business trips with higher productivity gains for Australian firms, and these gains benefit firms in both countries. Hovhannisyan and Keller (2015) find that international business trips promote local innovation, patenting, and growth for both countries.

Only a fraction of countries invest in $\mathrm{R} \& \mathrm{D}$ and innovate new products and processes and these innovations and technologies transfer to other countries through international trade and international mobility of people (Keller, 2004). Oettl and Agrawal (2008) and Kim et al. (2009) find that the movement of researchers promotes exchange of scientific knowledge among countries. Andersen and Dalgaard (2011) and Tani and Joyeux (2013) find that international travel promotes technology diffusion and productivity growth. Similarly, Le (2008, 2012) finds that knowledge diffuses across countries due to the mobility of highly skilled workers. If international mobility promotes technology diffusion, then any barriers to mobility across borders obstruct technology transfer.

Barriers to international mobility also impose additional cost of time and resources to the travelers; travelers must go through a lot of paper work, submit an application, pay a visa fee, and wait for a visa before traveling. This process also carries the uncertainty that a traveler may not get a visa from the host country. This increased cost along with the uncertainty decreases the flow of people among countries. As we saw above, business trips promote international trade. Business visas are generally granted for one year and the process takes several months, which can delay business and give comparative advantage to the firms located in countries requiring no visa to enter the potential market. 


\subsection{Trends in International Travel and Barriers to Mo- bility}

People travel abroad for a variety of reasons including, vacation, business, academic, religious work, performing athletic or artistic work, medical treatment, etc. International travel data shows a strong increasing trend during 1995-2012 and is expected to increase by 3.3 percent a year from 2010 to $2030{ }^{17}$ About 1.60 billion people crossed international borders in 2012 compared to 0.85 billion in 1995. This shows an increase of 86 percent in the total number of international travelers from 1995 to 2012.

International travel data also reveals regional variations. In 2012, the travel share of Europe and Central Asia was about 56 percent; the share of East Asia and the Pacific was about 22 percent; the share of Middle East and North Africa was about 4 percent; the share of Latin America and the Caribbean was about 4 percent; the share of South Asia was about 1.57 percent; and the share of Sub-Saharan Africa was 1.52 percent.

The distribution of international travel based on the income level of the home country also shows the same dispersion. In 2012, high income countries had the largest share in international travel (about 79 percent), followed by upper middle income countries (14 percent), lower middle income countries (6 percent), and low income countries (1 percent). This shows that rich countries have access to more foreign space compared to the poor countries.

The data for barriers to international mobility also show huge variation across countries. Table A2 shows the 20 most powerful and the 20 weakest passports in the world ${ }^{18}$ The ranking of a passport is based on the the ability of the passport holder to travel to other countries without requiring a prior visa. The list puts the German passport at the top with 158 visa free entries. The weakest passport list has Afghanistan at the top with only 24 visa free entries.

\footnotetext{
${ }^{17}$ see The UNWTO Tourism Highlights 2013 at http://www.e-unwto.org/doi/pdf/10.18111/9789284415427

${ }^{18}$ see https://www.passportindex.org for the complete list.
} 


\subsection{A Brief History of Barriers to Mobility}

Almost all states control the entry and exit of travelers at their national borders. This entry and exit is governed using passport, visa, and other identity documents. Some states use passport as a political instrument - to restrict travel across countries. For example, Israeli citizens need special permission to travel to Iran, Pakistan, Iraq, Libya, Lebanon, Saudi Arabia, Syria and Yemen.19 Similarly, Israeli passport holders are not accepted in some countries ${ }^{20}$ A most recent example of travel restrictions is the US executive order number 13769, signed by president Donald J. Trump on January 27, 2017. This order suspended the entry of travelers from seven countries in the US for 90 days. ${ }^{21}$ These types of travel restrictions and passport control are not new.

The oldest reference to a passport is found in the Hebrew Bible, in the book of Nehemiah. Nehemiah was a cup-bearer of the King Artaxerxes, the king of Persia (455 BC). Nehemiah wanted to travel to Judah to build a wall in Jerusalem. He asked the king of Persia to write him a letter so that the governors of the provinces across the river may allow him to pass through their territory safely. These types of letters became popular in Europe during the reign of King Louis XIV in 17th century. However, this system was completely abolished before WWI due to the arrival of a train system in Europe. The train system increased the volume of tourism as well as administration cost of visas and passport in Europe.

The travel restrictions were re-introduced after the WWI among the warring states (France, Germany, and Italy). Other neutral states such as Spain, Denmark, and Switzerland followed. There was always an effort to revert to a pre-war passport and visa free world. To achieve this goal, the first passport conference was held in Paris in 1920. This goal could not be achieved as the political conditions of the world had changed dramatically since WWI. The discussion of a visa free world remained till 1962, although passports and visas became new normal after WWII.

\footnotetext{
${ }^{19}$ These states, under Israeli law, are designated as "enemy states".

${ }^{20}$ Algeria, Bangladesh, Brunei, Iran, Iraq, Kuwait, Lebanon, Libya, Malaysia, Oman, Pakistan, Saudi Arabia, Sudan, Syria, United Arab Emirates, and Yemen.

21 The countries included in this list are Iran, Iraq, Libya, Somalia, Sudan, Syria and Yemen.
} 


\subsection{Data}

This section presents data description and data sources in detail. Annual bilateral data of 198 home countries and 30 OECD host countries ${ }^{22}$ during the period 2001-2012 is used in this study.

TFP Gap: TFP Gap is the total factor productivity gap between the host country $j$ and the home country $i$ at time $t$. It is calculated as the absolute difference between the TFP of the home and the host country.

$$
T F P \operatorname{Gap}_{i, j t}=\left|\ln \left(T F P_{j, t}\right)-\ln \left(T F P_{i, t}\right)\right|
$$

Notice that if $T F P_{i}=T F P_{j}$ then the TFP gap will be zero. This paper uses an improved measure of TFP ${ }^{23}$ reported in the Penn World Table version 8.1 (PWT 8.1). PWT 8.1 reports TFP accounting for variable labor share in GDP and variable depreciation rates across countries ${ }^{24}$ PWT 8.1 data are different from earlier studies, for example, Hall and Jones (1999) and Caselli (2005) constructed TFP by assuming a constant depreciation rate across countries and over time.

TFP, in PWT 8.1, is defined as

$$
T F P_{i, U S A}=\frac{G D P_{i}}{G D P_{U S A}} / Q_{i, U S A}
$$

where $G D P_{i}$ is the real GDP of the home country and $G D P_{U S A}$ is the real GDP of the base country, the U.S. $Q_{i, U S A}$ is the Tornqvist quantity index of factor inputs. It is the second order approximation to the production function.

$$
Q_{i, U S A}=\frac{1}{2}\left(\alpha_{i}+\alpha_{U S A}\right) \ln \frac{K_{i}}{K_{U S A}}\left[1-\frac{1}{2}\left(\alpha_{i}+\alpha_{U S A}\right)\right] \ln \frac{L_{i}}{L_{U S A}}
$$

Here $\alpha$ is the output elasticity of capital, $K$ is capital, and $L$ is labor in the respective country.

Visa Refusal Rate: The visa refusal rate is calculated as the number of visas refused divided by the total number of applications received. The data for visa refusal rate are

\footnotetext{
${ }^{22}$ see list of countries in the appendix.

${ }^{23}$ variable 'ctfp' in Penn World Table version 8.1.

${ }^{24}$ see Inklaar and Timmer (2013) and Feenstra et al. (2015) for a complete discussion
} 
taken from Hobolth (2012). This variable shows the intensity of barriers to mobility and, to the author's opinion, a better indicator of barriers to mobility. Visa requirement index shows whether the visa is required to enter a country or not but does not show the extent of barriers to mobility. If the citizens of two countries need a visa to travel to a host country, the citizens of the first country may get a visa very easily while excessive paper work may be required for the citizens of the second country, where most of the visas are denied. Thus, the barriers to mobility will be higher for the second country. Data for visa refusal rate are available for the period of 2001-2012.

Visa Restriction Index: This index is constructed by Hobolth (2012) and covers three dimensions of the barriers to mobility: visa requirements, visa issuing practice, and consular services. Visa requirement shows whether citizens of the home country need a visa to enter the host country or not. The visa issuing practice shows the intensity of restrictions and how many visas were granted as a share of total applications, and the consular service shows whether a visa application can be submitted in the home country. All the above three dimensions are given equal weight to calculate this index. This index is reported on a scale ranging from 0 to 3 , where 0 implies no barriers to mobility from the home country to the host country, and 3 implies high barriers to mobility from the home to the host country. To simplify the results, this paper uses only two categories: no barriers to mobility and barriers to mobility by merging the categories.

Visa Requirement Index: This index shows whether the citizens of the home country need a valid visa to enter the host country. This index is a binary variable and takes the value of 1 if the citizens of the home country require a visa to enter the host country and 0 otherwise. The data for this dummy variable are taken from Hobolth (2012).

Institutional Gap: This paper uses polity iv index as a measure of institution quality in a country, normalizing this index on a scale ranging from 0 to 125 where 0 indicates weak institutions and 1 indicates better quality institutions. The variable institution gap is calculated as the difference between the institution quality in the host and home country.

Polity IV is reported by Center for Systemic Peace. Some economists believe that the Polity index, compared to other measures of institutions, is a better measure of institution

\footnotetext{
${ }^{25}$ Spilimbergo (2009) and Barro (1999) also normalize this index on a scale ranging from 0 to 1.
} 
quality. The argument is that it shows the constraint on the executive while other measures of institutions are policy outcomes (Glaeser et al., 2004). The Polity IV dataset covers all major and independent states over the period 1800-2012 and reports polity scores on a scale ranging from -10 to 10, where 10 indicates a consolidated democracy and -10 indicates an autocracy.

Common Spoken Language (CSL): CSL is the probability that two individuals selected at random from two countries will understand each other. The value of CSL lies between 0 and 1 , where 0 indicates that the probability is zero that the pair will understand each other and 1 indicates that the probability that the pair will understand each other is one. The data for CSL are taken from CEPII. ${ }^{26}$

Capital Intensity Gap: This variable is calculated as the difference between the capital stock of the host and the home country. This variable captures the stock of knowledge in a country. Capital stock ${ }^{27}$ (millions of US dollar at constant prices) data are taken from Penn World Table version 8.1.

Other Variables: Other variables include physical distance between a country pair, genetic distance, and a dummy variable showing whether two countries share a common WTO/GATT status. Genetic distance is the probability that two randomly selected individuals from two populations will be different. The genetic distance between two populations is zero if and only if the two populations are identical. Data for genetic distance are taken from Spolaore and Wacziarg (2009). Data for physical distance and common WTO status are taken from CEPII.

\subsection{Empirical Analysis}

\subsubsection{Partial Correlations}

Figure 3.1 plots the average TFP gap and average visa refusal rate of each country during the sample period. Visually, the average TFP gap and average visa refusal rate show a high positive correlation. Table 3.2 presents a quick view of partial correlations between the

\footnotetext{
${ }^{26}$ see Melitz and Toubal (2014) for a complete exploration.

${ }^{27}$ variable 'rkna' in PWT 8.1.
} 
dependent variable, TFP gap, and the regressors. The correlation coefficient between the bilateral TFP gap and visa refusal rate is 0.43 . The correlation coefficient between bilateral TFP gap and the other two measures of barriers to mobility, visa restriction index and visa requirement index, is 0.38 . This provides the first evidence that barriers to mobility slow down the process of technology diffusion across countries.

\subsubsection{Specification}

The next step is to explore empirical evidence in favor of the causal relationship between the TFP gap and barriers to international mobility. In that respect, this paper features the percent gap between the total factor productivity of a country pair as the dependent variable and barriers to international mobility as the main explanatory variable. Other key factors that affect bilateral technology diffusion include difference between the institutions and difference between capital intensity in a country pair. Institutions are important because if the property rights are not secured, powerful groups may prevent the adoption of new technologies due to the fear of losing economic and political influence (Acemoglu and Robinson, 2001; Parente and Prescott, 1999). In this case, many producers will not be willing to adopt new technologies. On the other hand, good institutions decrease the transaction cost (North, 1990) and stimulate economic growth (Knack and Keefer, 1995; Dawson, 1998; Acemoglu et al., 2002; Acemoglu and Johnson, 2005).

Technology diffusion also depends on the geographic location of a country; countries in the proximity to the technological hubs may adopt more technologies due to a lower transportation cost. ${ }^{28}$ This paper uses distance between a country pair to account for this factor. Technology transfer also depends on the volume of international trade and foreign direct investment. ${ }^{29}$ This paper uses common WTO/GATT status to account for international trade and foreign direct investment. Finally, language can play a key role in the diffusion of technologies across countries. Countries speaking the same language may share more technologies due to the ease of communication.

To account for the above determinants of technology diffusion, this paper uses institution

\footnotetext{
${ }^{28}$ see Gallup et al. (1999).

${ }^{29}$ see Keller (2004) for a complete discussion.
} 
gap (the difference between the institution quality in a country pair), capital intensity gap (the difference between the capital stock of two countries), the physical distance between two countries, common spoken language, and common WTO status as control variables. Specifically, the following model is used

$$
\text { TFP } \text { Gap }_{i, j t}=\beta_{0}+\beta_{1} \text { Barriers to Mobility }_{i, j t}+X_{i, j t}^{\prime} \beta_{2}+\epsilon_{i j t}
$$

where the TFP Gap is the absolute total factor productivity gap between the host country $j$ and the home country $i$ at time $t$. It is defined as

$$
T F P \operatorname{Gap}_{i, j t}=\left|\ln \left(T F P_{j, t}\right)-\ln \left(T F P_{i, t}\right)\right|
$$

Notice that if $T F P_{i}=T F P_{j}$ then the TFP gap will be zero.

Barriers to Mobility ${ }_{i, j t}$ indicate the barriers to mobility faced by the citizens of country $i$ from country $j$ in year $t$. To account for barriers to mobility, this paper uses three measures: visa refusal rate, visa restriction index, and visa requirement index. $X_{i, j t}$ is a vector of control variables containing institution gap (Institution Gap $p_{i, j t}$ ), distance between $i t h$ and $j$ th country $\left(\right.$ Distance $_{i, j}$ ), difference in the capital intensity in a country pair (Capital Intensity Gap I $_{i, j t}$ ), dummy variable indicating whether ith and $j$ th countries have a common WTO/GATT status (Common WTO Status $_{i, j t}$ ), and the probability that two randomly selected individuals from two countries speak the same language (Common Spoken Language). Finally, $\epsilon_{i j t}$ captures the omitted variables and noise.

\subsubsection{OLS Estimation}

Table 3.3 shows OLS estimates for TFP gap as a dependent variable and visa refusal rate as the main explanatory variable. Column 1-3 reports estimation results for visa refusal rate as the only explanatory variable. Column 1 does not include any time and country fixed effects. Column 2 adds time fixed effects and column 3 adds time fixed effects, host country fixed effects, and home country fixed effects. Visa refusal rate explains about 19 percent of the variation in the dependent variable in column 1, 13 percent in column 2, and 92 percent of the variation in column 3. Visa refusal rate has a positive and statistically significant coefficient in column 1-3. 
Column 4-7 present the estimation results for visa refusal rate, as the main explanatory variable, and include other control variables in the model. The explanatory power of this model is in the range of 11 to 21 percent. The main explanatory variable, visa refusal rate, has a positive and statistically significant coefficient with an elasticity of about about 0.04 , indicating that 10 percent increase in the visa refusal rate increases bilateral TFP gap by 0.40 percent. Starting from the zero bilateral TFP gap, if visa refusal rate increases by 10 percent, the bilateral TFP gap increases from 0 to about 0.40 percent. The average visa refusal rate in the sample is about 12 percent. This indicates that the average bilateral TFP gap is increasing by about 0.48 percent due to the visa refusal rate. The average annual visa refusal rate for the top 20 most restricted countries is about 40 percent. This shows that the TFP gap is increasing by about 1.6 percent for these countries. The average TFP gap in the sample is about 14 percent. This implies that the TFP gap, on average, will increase from 14 to 14.40 percent due to visa refusal rate.

To check the robustness of the results two additional measures of barriers to mobility, visa restriction index and visa requirement index, are also used. The estimation results for these two measures of barriers to mobility are presented in table 3.4. Column 1 presents visa restriction index as the main explanatory variable. Visa restriction index is a dummy variable, where 0 implies no barriers and 1 implies barriers to mobility from the home to the host country. Visa restriction index explains about 20 percent of the variation in the dependent variable and has a positive and statistically significant coefficient with a value of 0.08. Starting from the zero bilateral TFP gap, if the host country imposes barriers to mobility on the home country, the bilateral TFP gap becomes about 0.08 percent.

Column 2 presents visa requirement index as the main explanatory variable. Visa requirement index is a dummy variable and takes the value of 1 if a visa is required to travel from the home to the host country. Visa requirement index explains about 20 percent of the variation in the dependent variable and has a positive and statistically significant coefficient with a value of 0.08 . To quantify the magnitude of visa requirement, let's start from a zero bilateral TFP gap. If the host country switches from a visa free country to visa required country, the bilateral TFP gap increases to about 0.08 percent. 


\subsubsection{Estimation}

\section{Dealing with Endogeneity}

A concern is that the visa refusal rate may be endogenous with TFP gap in the above model. A low TFP home (developing country) may face high barriers to mobility from a high TFP (advanced) host country. In this case, we have a reverse causality issue. The advanced country may impose high barriers to mobility on the citizens of the developing country to stop illegal immigration. To address this issue, this paper uses genetic distance as an instrumental variable for visa refusal rate. Genetic distance is the probability that two randomly selected individuals from two populations will be different. The genetic distance between two populations is zero if and only if the two populations are identical ${ }^{30}$ The underlying assumption is that genetic dissimilarity (a larger genetic distance between two populations) increases mistrust between population: 31 and, hence, increases barriers to international mobility. A further concern is that current genetic distance may be correlated with the TFP gap. This may be due to the factors such as migration. For example, European colonizers settled in the regions suitable to them. This migration pattern may explain not only the current TFP gap but also the genetic distance between populations today.

These issues are resolved using 3SLS model. In the first stage, this paper uses genetic distance in $1500 \mathrm{AD}$ as an instrumental variable for current genetic distance. The fitted values of current genetic distance are then used as an instrument for visa refusal rate in our main model. Genetic distance in $1500 \mathrm{AD}$ is from the period prior to industrial revolution and great migration. We can argue that genetic distance in $1500 \mathrm{AD}$ does not affect bilateral TFP gap today. More specifically, the below 3SLS model is estimated.

$$
\begin{gathered}
\text { TFP Gap } \text { G }_{i, j}=\beta_{0}+\beta_{1} \ln \left(\text { Visa Refusal Rate } e_{i, j t}\right)+X_{i, j t}^{\prime} \beta_{2}+\epsilon_{i j t} \\
\text { Visa Refusal Rate }_{i, j t}=\gamma_{0}+\gamma_{1} \text { Genetic Distance }_{i, j}+\eta_{i j t} \\
\text { Genetic Distance }_{i, j}=\lambda_{0}+\lambda_{1} \text { Genetic Distance }_{i, j}^{1500 A D}+\phi_{i j}
\end{gathered}
$$

\footnotetext{
${ }^{30}$ see Spolaore and Wacziarg (2009) for a complete exposition to genetic distance and its effect on barriers to technology transfer.

31 see for example Guiso et al. (2009).
} 


\section{First-stage Estimation}

Table 3.5 shows the correlation between endogenous variables. The correlation coefficient between current genetic distance and genetic distance in 1500 is 0.73 . Table 3.6 shows that the genetic distance in 1500 explains about 53 percent of the variation in current genetic distance among countries. The coefficient for genetic distance in 1500 is statistically significant and positive. Table 3.5 and 3.6 also show that the correlation coefficient between visa refusal rate and current genetic distance is 0.42 . Current genetic distance explains about 20 percent of the variation in the visa refusal rate and has a positive and statistically significant coefficient value. These results and F-test confirm the validity of the instruments.

\section{Estimation Results}

Table 3.7 reports 2LS and 3SLS estimates for TFP gap as a dependent variable and visa refusal rate as an independent variable. Column 1 reports 2SLS estimation results. Current genetic distance between countries is used as an instrumental variable for visa refusal rate in this model. Visa refusal rate has a positive and statistically significant coefficient. Starting from the zero bilateral TFP gap, if visa refusal rate increases by one percent, the bilateral TFP gap increases from 0 to about 0.54 percent. Column 2 reports 3SLS results for TFP gap as a dependent variable. Genetic distance in 1500 is used as an instrument for current genetic distance. The fitted values of current genetic distance are then used as an instrumental variable for visa refusal rate. Using this model, we were able to isolate the effects of European migration and industrial revolution on current TFP gap and barriers to mobility. Visa refusal rate has a positive and statistically significant coefficient in this model. The coefficient value for visa refusal rate is about 30 percent lower from the 2 SLS coefficient (0.54 vs. 0.38) and about 10 times larger than the OLS (0.04 vs. 0.38). Nevertheless, the statistical significance of visa refusal rate supports the hypothesis that barriers to international mobility slow down the process of international technology diffusion.

To quantify the magnitude of 2SLS and 3SLS coefficients, let's start from the zero bilateral TFP gap, if visa refusal rate increases by 10 percent, the bilateral TFP gap increases between 3.8 to 5.4 percent. The average visa refusal rate in the sample is about 12 percent. This 
indicates that the average bilateral TFP gap increases in the range of 4 to 5 percent due to the visa refusal rate. The average TFP gap in the sample is about 14 percent. This implies that the TFP gap, on average, will increase from 14 to 19 percent due to visa refusal rate.

Controlling for Other Factors: Other control variables in the model show expected and robust coefficients across all three measures of barriers to mobility and across different estimation methods: OLS, 2SLS, and 3SLS. Variable institution gap, showing bilateral difference in the institutional arrangements, has a positive and statistically significant effect on the TFP gap. This indicates the important role of institutions in the diffusion of technologies. Capital intensity gap has a positive and statistically significant coefficient value. Distance between the home and the host country has a positive effect on the TFP gap. This indicates that geographic location is very important for technology diffusion; countries located near the technology hubs have a higher technology adoption rate. Finally, common spoken language and common WTO status have negative coefficient values. Common language shows the ease of communication which facilitates the diffusion of technologies. Common WTO status captures the effect of international trade and foreign direct investment. The results show that countries with a high volume of bilateral trade and foreign direct investment, on average, have lower TFP gap.

\subsubsection{Logit Model Estimation}

To further test the robustness of the results, the dependent variable is turned into a dummy variable. This variable takes the value of 1 whenever host country has a higher TFP than the home country, and 0 otherwise i.e.

$$
\text { TFP Gap }= \begin{cases}1, & \text { if } T F P_{j t}>T F P_{i t} \\ 0, & \text { otherwise }\end{cases}
$$

As the dependent variable is a binary variable, the logit model can estimate this model. The results, in table 3.8, indicate that if the visa refusal rate increases by one percent, there is 12 percent more chance that the home country has lower TFP relative to the partner country (a high TFP gap). The results for the other two measures of barriers to mobility indicate that 
if the home country faces barriers to mobility from the partner country, it is 30 percent more likely to have lower TFP relative to the partner country. Similarly, if the visa is required to travel to the partner country there is a 30 percent more chance that home country has lower TFP relative to the partner country.

A country is 40 percent more likely to have a lower TFP relative to its partner, if its institutions are weak relative to the partner country. A country is about 8 percent less likely to have a TFP gap if it shares common WTO status with the partner country. A one percent increase in the capital intensity difference between a country pair implies 5 percent more likelihood of a bilateral TFP gap. A one percent increase in the distance between a country pair implies 9 percent more likelihood of a bilateral TFP gap.

To summarize the above results, overall evidence suggests that there is a strong relationship between barriers to international mobility and technology diffusion. The international TFP gap increases as the barrier to international mobility increases. The results are robust across three measures of barriers to mobility as well as across different estimation techniques. Hence, this paper sheds light on the slow diffusion of international technologies ${ }^{32}$

\subsection{Concluding Remarks}

International mobility plays a key role in exposing societies to superior technologies and production processes outside their national borders and, hence, facilitates the diffusion of technologies. On the other hand, any barriers to international mobility can slow down the spread of technologies across countries. This paper uses bilateral visa restrictions data of 30 host countries and 198 home countries between 2001-2012 to investigate the implications of barriers to mobility on international technology diffusion. The results indicate that barriers to international mobility impede the spread of technologies across countries. Barriers to international mobility have a statistically significant and positive effect on bilateral TFP gap. The visa refusal rate shows that the TFP gap among countries increases as the visa refusal rate increases. Hence, this paper builds a case that the international TFP gap

\footnotetext{
${ }^{32}$ Although this paper does not study TFP convergence directly, I checked the robustness of the results by using the system GMM. The results show that visa refusal rate has a statistically significant effect on the growth of TFP gap. The results are available on request.
} 
increases as the barrier to international mobility increases. These results are robust across all three measures of barriers to mobility.

Important policy implications include initiating visa facilitation programs with advanced countries. These visa facilitation program will promote cultural and scientific exchange and stimulate technology diffusion across countries. The present paper focuses on the one-way effects of barriers to mobility - technology diffusion from the host to the home country. The future research could incorporate two-way effects to explore, how the bilateral barriers to mobility affect bilateral technology diffusion.

\subsection{Appendix}


Figure 3.1: Relationship between Visa Refusal Rate and TFP Gap

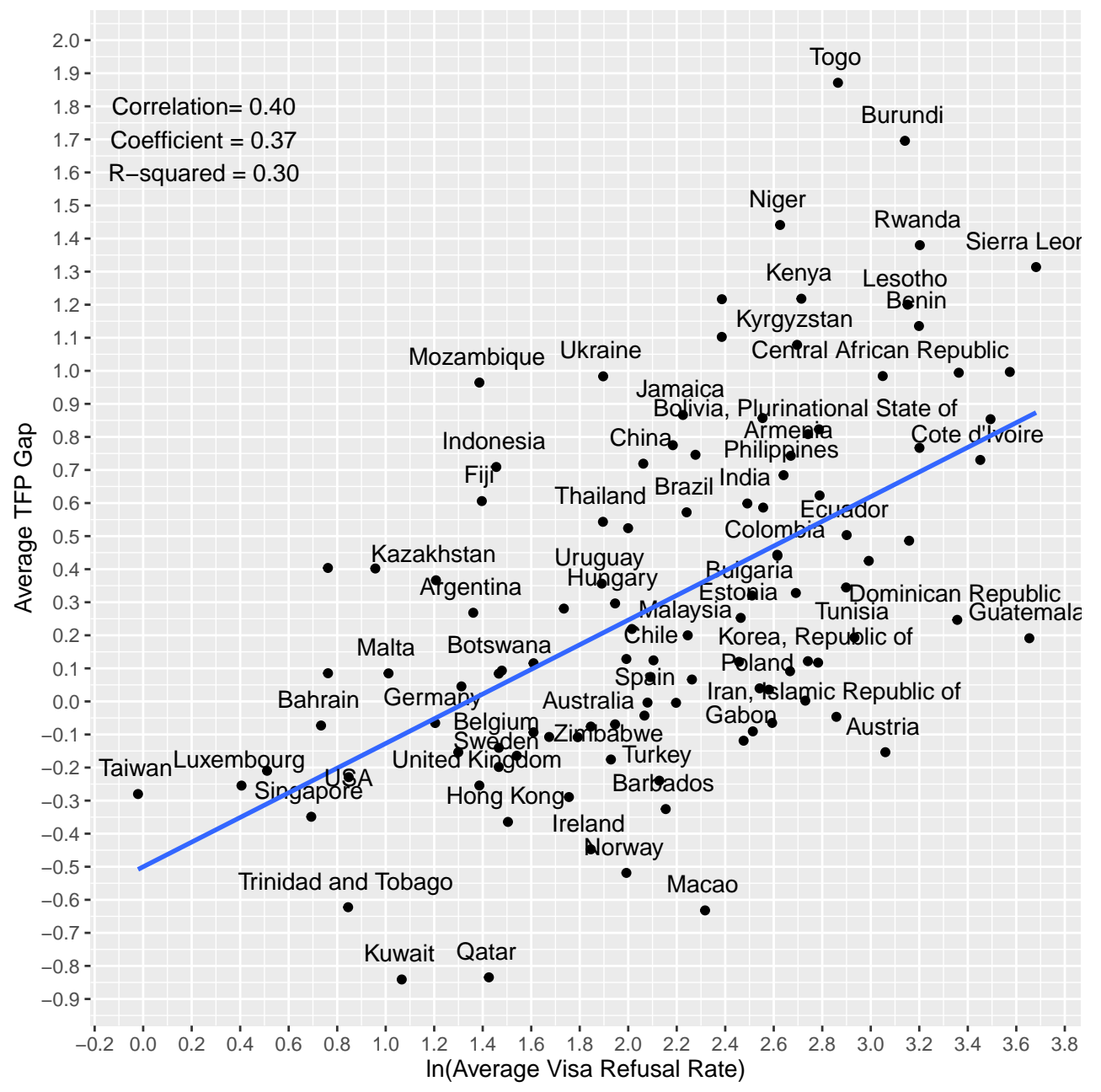

Notes: Average visa refusal rate and average TFP gap refer to the averages during the sample period across all host countries i.e. $\bar{X}_{i}=\sum_{j=1}^{J} \sum_{t=1}^{T} X_{j t}$. 
Figure 3.2: Most Restricted Countries of the World

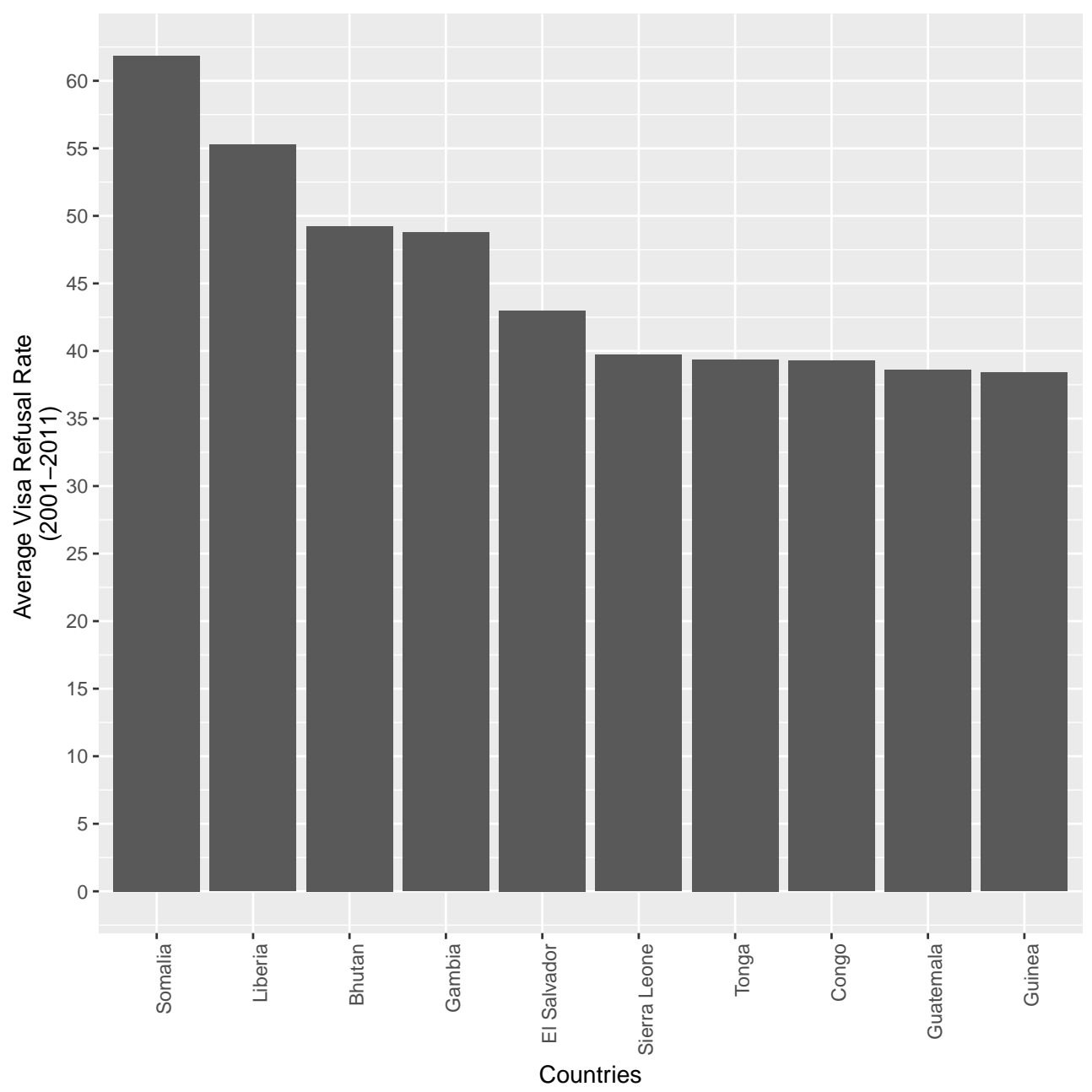

Notes: Averages are based on the visa refusal rate data from Hobolth (2012). 
Figure 3.3: South Africa

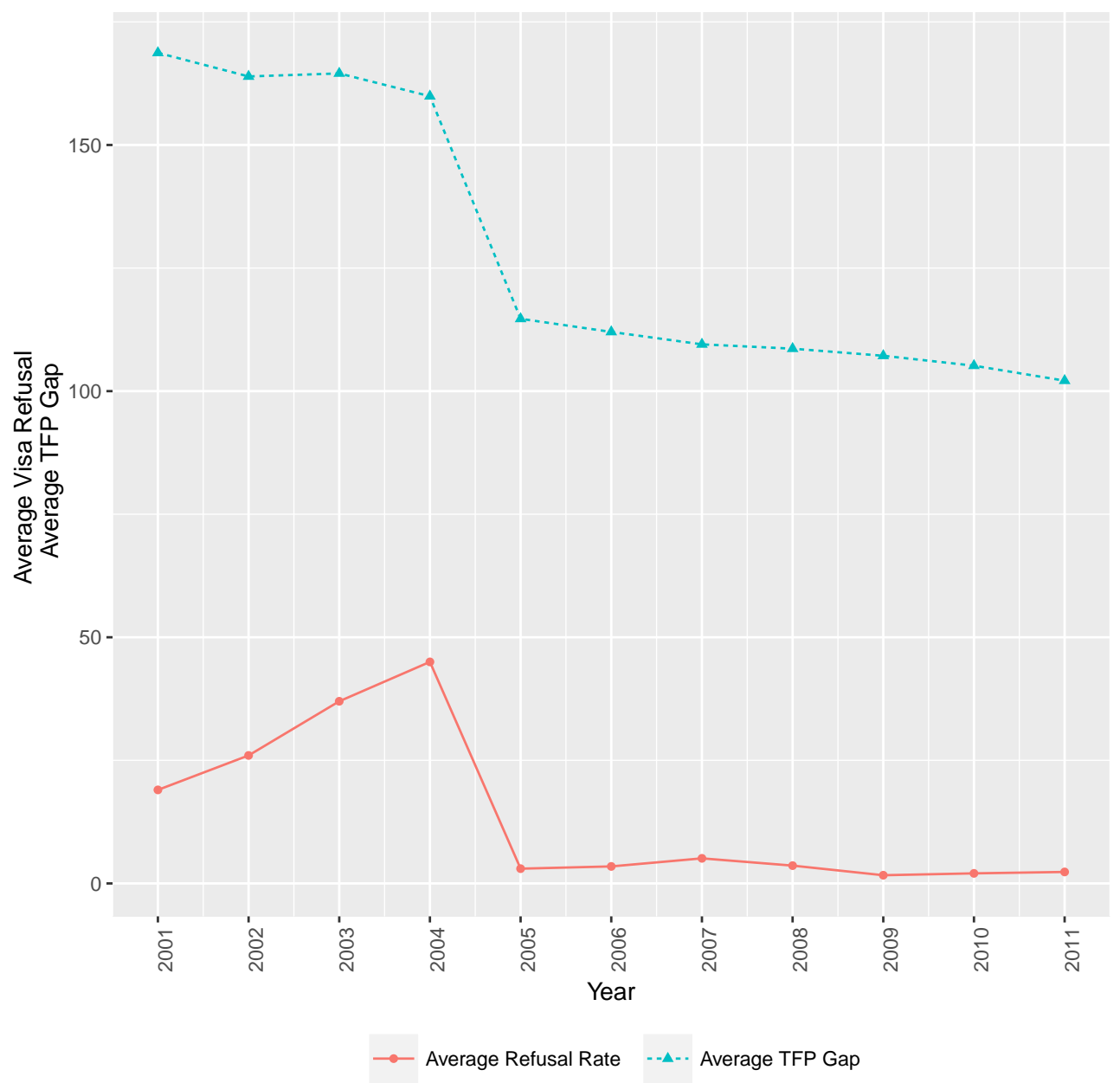

Notes: Averages are based on the visa refusal rate data from Hobolth (2012) and TFP data from PWT 8.1. 
Table 3.1: Descriptive Statistics

\begin{tabular}{|c|c|c|c|c|c|}
\hline Statistic & $\mathrm{N}$ & Mean & St. Dev. & Min & $\operatorname{Max}$ \\
\hline $\ln \left(\%\right.$ TFP $\left.\operatorname{Gap}_{i, j t}\right)$ & $21,956.00$ & 1.33 & 0.67 & 0.31 & 7.47 \\
\hline $\ln \left(\right.$ Visa Refusal Rate $\left._{i, j t}\right)$ & $17,357.00$ & 1.01 & 1.32 & 0.00 & 4.62 \\
\hline Visa Restriction Index ${ }_{i, j t}$ & $13,453.00$ & 0.61 & 0.49 & 0.00 & 1.00 \\
\hline Visa Requirement Index $x_{i, j t}$ & $13,453.00$ & 0.61 & 0.49 & 0.00 & 1.00 \\
\hline Institution $\operatorname{Gap}_{i, j t}$ & $19,551.00$ & 0.78 & 0.28 & -0.10 & 1.00 \\
\hline $\ln \left(\right.$ Capital Intensity $\left.\operatorname{Gap}_{i, j t}\right)$ & $21,956.00$ & 2.23 & 1.63 & 0.00 & 8.65 \\
\hline $\ln \left(\right.$ Income Difference $\left._{i, j t}\right)$ & $21,956.00$ & 2.15 & 1.56 & 0.00 & 8.47 \\
\hline $\ln \left(\right.$ Distance $\left._{i, j}\right)$ & $20,796.00$ & 8.29 & 0.95 & 5.08 & 9.88 \\
\hline Common Spoken Language $_{i, j}$ & $21,018.00$ & 0.22 & 0.25 & 0.00 & 1.00 \\
\hline Common WTO Status $_{i, j t}$ & $21,956.00$ & 0.93 & 0.25 & 0.00 & 1.00 \\
\hline Genetic Distance $_{i, j}$ & $61,661.00$ & 0.03 & 0.02 & 0.00 & 0.07 \\
\hline Genetic Distance in $1500 \mathrm{AD}_{i, j}$ & $61,661.00$ & 0.04 & 0.02 & 0.00 & 0.08 \\
\hline
\end{tabular}


Table 3.2: Correlation Matrix

\begin{tabular}{|c|c|c|c|c|c|c|c|c|c|c|c|c|}
\hline $\ln \left(\%\right.$ TFP $\left.\operatorname{Gap}_{i, j t}\right)$ & 1.00 & & & & & & & & & & & \\
\hline $\ln \left(\right.$ Visa Refusal Rate Rijt $\left._{i}\right)$ & 0.43 & 1.00 & & & & & & & & & & \\
\hline Visa Requirement Index ${ }_{i, j t}$ & 0.38 & 0.82 & 1.00 & & & & & & & & & \\
\hline Visa Restriction Index ${ }_{i, j t}$ & 0.38 & 0.82 & 1.00 & 1.00 & & & & & & & & \\
\hline Institution $\operatorname{Gap}_{i, j t}$ & -0.14 & -0.48 & -0.56 & -0.56 & 1.00 & & & & & & & \\
\hline $\ln \left(\right.$ Capital Intensity $\left.\mathrm{Gap}_{i, j t}\right)$ & 0.32 & 0.26 & 0.20 & 0.20 & -0.13 & 1.00 & & & & & & \\
\hline $\ln \left(\right.$ Income Difference $\left._{i, j t}\right)$ & 0.28 & 0.21 & 0.16 & 0.16 & -0.10 & 0.95 & 1.00 & & & & & \\
\hline $\ln \left(\right.$ Distance $\left._{i, j}\right)$ & 0.23 & 0.20 & 0.34 & 0.34 & -0.17 & 0.17 & 0.15 & 1.00 & & & & \\
\hline Common Spoken Language $_{i, j}$ & -0.20 & -0.31 & -0.46 & -0.46 & 0.37 & -0.01 & 0.04 & -0.37 & 1.00 & & & \\
\hline Common WTO Status ${ }_{i, j t}$ & -0.06 & -0.18 & -0.26 & -0.26 & 0.34 & 0.04 & 0.03 & 0.03 & 0.16 & 1.00 & & \\
\hline $\ln \left(\right.$ Genetic Distance $\left._{i, j}\right)$ & 0.42 & 0.42 & 0.48 & 0.48 & -0.25 & 0.26 & 0.22 & 0.63 & -0.35 & 0.09 & 1.00 & \\
\hline $\ln \left(\right.$ Genetic Distance in $\left.1500 \mathrm{AD}_{i, j}\right)$ & 0.27 & 0.18 & 0.25 & 0.25 & -0.04 & 0.22 & 0.20 & 0.83 & -0.28 & 0.13 & 0.73 & 1.00 \\
\hline
\end{tabular}


Table 3.3: Dependent Variable: Bilateral TFP Gap (percent)

\begin{tabular}{|c|c|c|c|c|c|c|c|}
\hline & $(1)$ & $(2)$ & $(3)$ & $(4)$ & $(5)$ & $(6)$ & $(7)$ \\
\hline VARIABLES & OLS & OLS & OLS & OLS & OLS & OLS & OLS \\
\hline \multirow[t]{2}{*}{$\ln \left(\right.$ Visa Refusal Rate $\left._{i, j t}\right)$} & $0.057 * * *$ & $0.042^{* * *}$ & $0.016^{* * *}$ & $0.045^{* * *}$ & $0.037^{* * *}$ & $0.036^{* * *}$ & $0.036^{* * *}$ \\
\hline & $(0.007)$ & $(0.006)$ & $(0.005)$ & $(0.006)$ & $(0.006)$ & $(0.006)$ & $(0.006)$ \\
\hline \multirow[t]{2}{*}{ 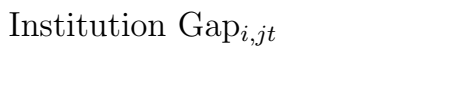 } & & & & $0.167^{* * *}$ & & & $0.247^{* * *}$ \\
\hline & & & & $(0.034)$ & & & $(0.035)$ \\
\hline \multirow[t]{2}{*}{$\ln \left(\right.$ Capital Intensity $\left.\operatorname{Gap}_{i, j t}\right)$} & & & & & $0.133^{* * *}$ & & 0.001 \\
\hline & & & & & $(0.012)$ & & $(0.045)$ \\
\hline \multirow[t]{2}{*}{$\ln \left(\right.$ Income Difference $\left._{i, j t}\right)$} & & & & & & $0.147^{* * *}$ & $0.143^{* * *}$ \\
\hline & & & & & & $(0.018)$ & $(0.053)$ \\
\hline \multirow[t]{2}{*}{$\ln \left(\right.$ Distance $\left._{i, j}\right)$} & & & & & & & $0.082^{* * *}$ \\
\hline & & & & & & & $(0.010)$ \\
\hline \multirow[t]{2}{*}{ Common Spoken Language $_{i, j}$} & & & & & & & $-0.424^{* * *}$ \\
\hline & & & & & & & $(0.055)$ \\
\hline \multirow[t]{2}{*}{ Common WTO Status $_{i, j t}$} & & & & & & & $-0.077^{* *}$ \\
\hline & & & & & & & $(0.037)$ \\
\hline Observations & 17,357 & 17,357 & 17,357 & 17,357 & 17,357 & 17,357 & 17,357 \\
\hline R-squared & 0.19 & 0.13 & 0.92 & 0.11 & 0.20 & 0.17 & 0.21 \\
\hline Number of countries & 2,454 & 2,454 & 2,454 & 2,454 & 2,454 & 2,454 & 2,454 \\
\hline Time Fixed Effect & $\times$ & $\checkmark$ & $\checkmark$ & $\checkmark$ & $\checkmark$ & $\checkmark$ & $\checkmark$ \\
\hline Host Country Fixed Effect & $\times$ & $\times$ & $\checkmark$ & $\times$ & $\times$ & $\times$ & $\times$ \\
\hline Home Country Fixed Effect & $x$ & $x$ & $\checkmark$ & $x$ & $x$ & $x$ & $\times$ \\
\hline
\end{tabular}

Notes: ${ }^{* * *} \mathrm{p}<0.01,{ }^{* *} \mathrm{p}<0.05,{ }^{*} \mathrm{p}<0.1$. Robust standard errors in parentheses. Ordinary least squares estimates. The dependent variable is the bilateral total factor productivity gap between the host and the home country. Visa refusal rate is the number of visa applications denied as a share of total applications. The sample is an unbalanced panel, comprising annual bilateral data between 2001-2012. 
Table 3.4: Dependent Variable: Bilateral TFP Gap (percent)

\begin{tabular}{|c|c|c|}
\hline & (1) & $(2)$ \\
\hline VARIABLES & OLS & OLS \\
\hline Visa Restriction Index ${ }_{i, j t}$ & $\begin{array}{c}0.082^{* * *} \\
(0.020)\end{array}$ & \\
\hline Visa Requirement Index ${ }_{i, j t}$ & & $\begin{array}{c}0.080^{* * *} \\
(0.020)\end{array}$ \\
\hline Institution $\operatorname{Gap}_{i, j t}$ & $\begin{array}{c}0.282^{* * *} \\
(0.039)\end{array}$ & $\begin{array}{c}0.282^{* * *} \\
(0.039)\end{array}$ \\
\hline $\ln \left(\right.$ Capital Intensity $\left.\operatorname{Gap}_{i, j t}\right)$ & $\begin{array}{l}-0.015 \\
(0.053)\end{array}$ & $\begin{array}{l}-0.015 \\
(0.053)\end{array}$ \\
\hline $\ln \left(\right.$ Income Difference $\left.{ }_{i, j t}\right)$ & $\begin{array}{c}0.171^{* * *} \\
(0.061)\end{array}$ & $\begin{array}{c}0.171^{* * *} \\
(0.062)\end{array}$ \\
\hline $\ln \left(\right.$ Distance $\left._{i, j}\right)$ & $\begin{array}{c}0.111^{* * *} \\
(0.012)\end{array}$ & $\begin{array}{c}0.111^{* * *} \\
(0.012)\end{array}$ \\
\hline Common Spoken Language $_{i, j}$ & $\begin{array}{c}-0.529 * * * \\
(0.065)\end{array}$ & $\begin{array}{c}-0.530 * * * \\
(0.065)\end{array}$ \\
\hline Common WTO Status $_{i, j t}$ & $\begin{array}{l}-0.045 \\
(0.034)\end{array}$ & $\begin{array}{l}-0.045 \\
(0.034)\end{array}$ \\
\hline Observations & 13,453 & 13,453 \\
\hline R-squared & 0.20 & 0.20 \\
\hline Number of countries & 2,177 & 2,177 \\
\hline Time Fixed Effect & $\checkmark$ & $\checkmark$ \\
\hline Host Country Fixed Effect & $\times$ & $\times$ \\
\hline Home Country Fixed Effect & $x$ & $x$ \\
\hline
\end{tabular}

Notes: ${ }^{* * *} \mathrm{p}<0.01,{ }^{* *} \mathrm{p}<0.05, * \mathrm{p}<0.1$. Robust standard errors in parentheses. Ordinary least squares estimates. The dependent variable is the bilateral total factor productivity gap between the host and the home country. Visa restriction index is a dummy variable and take the value of 0 if there are no barriers to mobility from the home to the host country. Visa Requirement index is a dummy variable and take the value 1 if visa is required to travel from the home country to the host country. The sample is an unbalanced panel, comprising annual bilateral data between 2001-2012. 
Table 3.5: Correlation between Endogenous Variables

$\ln \left(\right.$ Visa Refusal Rate $\left._{i, j t}\right) \quad \ln \left(\right.$ Genetic Distance $\left._{i, j}\right) \quad \ln \left(\right.$ Genetic Distance in $\left.1500 \mathrm{AD}_{i, j}\right)$

\begin{tabular}{llll}
\hline $\ln \left(\right.$ Visa Refusal Rate $\left._{i, j t}\right)$ & 1.00 & & \\
$\ln ($ Genetic Distance & & \\
$i, j$ & 0.42 & 00 & 1.00 \\
$\ln \left(\right.$ Genetic Distance in $\left.1500 \mathrm{AD}_{i, j}\right)$ & 0.18 & 0.73 & 1.00 \\
\hline
\end{tabular}

Table 3.6: Dependent Variable: $\ln ($ Visa Refusal Rate)

VARIABLES

Visa Refusal Rate Genetic Distance

$\ln ($ Genetic Distance $i, j)$

$\ln \left(\right.$ Genetic Distance in $\left.1500 \mathrm{AD}_{i, j}\right)$

\begin{tabular}{lcc}
\hline Observations & 17,357 & 17,357 \\
R-squared & 0.20 & 0.53 \\
F First Stage & 420.92 & 1659 \\
\hline Time Fixed Effect & $\checkmark$ & $\checkmark$ \\
\hline
\end{tabular}

Notes: $* * * \mathrm{p}<0.01,{ }^{* *} \mathrm{p}<0.05, * \mathrm{p}<0.1$. Robust standard errors in parentheses. Ordinary least squares estimates. The dependent variable in column 1 is visa refusal rate and column 2 is current genetic distance. Visa refusal rate is the number of visa applications denied as a share of total applications. Genetic distance is the probability that two randomly selected individuals from two populations will be different. The sample is an unbalanced panel comprising annual bilateral data between 2001-2012. 
Table 3.7: IV Estimation

\begin{tabular}{lcc}
\hline & $(1)$ & $(2)$ \\
VARIABLES & 2 SLS & 3 SLS \\
\hline \multirow{2}{l}{$\left(\right.$ Visa Refusal Rate $\left._{i, j t}\right)$} & $0.536^{* * *}$ & $0.378^{* * *}$ \\
& $(0.014)$ & $(0.045)$ \\
Institution Gap $_{i, j t}$ & $1.022^{* * *}$ & $0.145^{*}$ \\
& $(0.032)$ & $(0.079)$ \\
$\ln \left(\right.$ Capital Intensity Gap $\left._{i, j t}\right)$ & $0.063^{* * *}$ & $0.183^{* * *}$ \\
& $(0.011)$ & $(0.015)$ \\
$\ln \left(\right.$ Income Difference $\left._{i, j t}\right)$ & -0.008 & $-0.059^{* * *}$ \\
& $(0.010)$ & $(0.011)$ \\
$\ln \left(\right.$ Distance $\left._{i, j}\right)$ & $0.055^{* * *}$ & $-0.032^{* * *}$ \\
& $(0.006)$ & $(0.006)$ \\
Common Spoken Language & $0.060^{* *}$ & $-0.235^{* * *}$ \\
& $(0.026)$ & $(0.037)$ \\
Common WTO Status $i, j t$ & $-0.158^{* * *}$ & $-0.395^{* * *}$ \\
& $(0.022)$ & $(0.022)$ \\
\hline Time Fixed Effect & & \\
\hline Observations & 17,357 & 17,357 \\
\hline
\end{tabular}

Notes: ${ }^{* * *} \mathrm{p}<0.01,{ }^{* *} \mathrm{p}<0.05, * \mathrm{p}<0.1$. Robust standard errors in parentheses. Two-stage least squares estimates in column 1. Three-stage least squares estimates in column 2. The dependent variable is the bilateral total factor productivity gap between the host and the home country. Visa refusal rate is the number of visa applications denied as a share of total applications. Current genetic distance between a country pair is used as an instrument for visa refusal rate in column 1. For 3SLS, genetic distance in 1500 $\mathrm{AD}$ is used as an instrument for current genetic distance. The fitted values of current genetic distance are then used as an instrument for visa refusal rate in column 3. Genetic distance is the probability that two randomly selected individuals from two populations will be different. The sample is an unbalanced panel comprising annual bilateral data between 2001-2012. 
Table 3.8: Dependent Variable: Does TFP Gap between Country $i$ and Country $j$ Exist? (Yes=1, $\mathrm{No}=0$ )

\begin{tabular}{|c|c|c|c|}
\hline VARIABLES & Logit Model & Logit Model & Logit Model \\
\hline $\ln \left(\right.$ Visa Refusal Rate $\left._{i, j t}\right)$ & $\begin{array}{c}0.116^{* * *} \\
(0.004)\end{array}$ & & \\
\hline Visa Restriction Index ${ }_{i, j t}$ & & $\begin{array}{c}0.307^{* * *} \\
(0.012)\end{array}$ & \\
\hline Visa Requirement Index $_{i, j t}$ & & & $\begin{array}{c}0.306^{* * *} \\
(0.012)\end{array}$ \\
\hline Institution $\operatorname{Gap}_{i, j t}$ & $\begin{array}{c}0.392^{* * *} \\
(0.016)\end{array}$ & $\begin{array}{c}0.428^{* * *} \\
(0.017)\end{array}$ & $\begin{array}{c}0.427^{* * *} \\
(0.017)\end{array}$ \\
\hline $\ln \left(\right.$ Capital Intensity $\left.\operatorname{Gap}_{i, j t}\right)$ & $\begin{array}{c}0.045^{* * *} \\
(0.003)\end{array}$ & $\begin{array}{c}0.047^{* * *} \\
(0.003)\end{array}$ & $\begin{array}{c}0.047^{* * *} \\
(0.003)\end{array}$ \\
\hline $\ln \left(\right.$ Distance $\left._{i, j}\right)$ & $\begin{array}{c}0.092^{* * *} \\
(0.005)\end{array}$ & $\begin{array}{c}0.086^{* * *} \\
(0.005)\end{array}$ & $\begin{array}{c}0.086^{* * *} \\
(0.005)\end{array}$ \\
\hline Common Spoken Language ${ }_{i, j}$ & $\begin{array}{c}0.014 \\
(0.020)\end{array}$ & $\begin{array}{c}0.041^{* *} \\
(0.021)\end{array}$ & $\begin{array}{c}0.041^{* *} \\
(0.021)\end{array}$ \\
\hline Common WTO Status $_{i, j t}$ & $\begin{array}{c}-0.080^{* * *} \\
(0.015)\end{array}$ & $\begin{array}{c}-0.034^{* *} \\
(0.015)\end{array}$ & $\begin{array}{c}-0.034^{* *} \\
(0.015)\end{array}$ \\
\hline Observations & 12,631 & 12,631 & 12,631 \\
\hline
\end{tabular}

Notes: ${ }^{* * *} \mathrm{p}<0.01,{ }^{* *} \mathrm{p}<0.05,{ }^{*} \mathrm{p}<0.1$. Standard errors in parentheses. Logit model marginal effects at the means. The dependent variable is a binary variable and indicates whether the bilateral TFP gap exists. Visa refusal rate is the number of visa applications denied as a share of total applications. Visa restriction index is a dummy variable and take the value of 0 if there are no barriers to mobility from the home to the host country. Visa Requirement index is a dummy variable and take the value 1 if visa is required to travel from the home country to the host country. The sample is an unbalanced panel, comprising annual bilateral data between 2001-2012. 
Table A1: Country-wise Average Visa Refusal Rates (2001-2012)

\begin{tabular}{|c|c|c|c|c|c|c|c|c|c|c|c|}
\hline Afghanistan & 21.18 & Central African Republic & 29.54 & Greece & 9.85 & Lesotho & 24.78 & Norway & 7.42 & Spain & 7.66 \\
\hline Albania & 16.41 & Chad & 22.62 & Grenada & 26.83 & Liberia & 56.83 & Oman & 2.97 & Sri Lanka & 22.43 \\
\hline Algeria & 27.57 & Chile & 11.70 & Guatemala & 8.60 & Libya & 9.74 & Pakistan & 34.09 & Sudan & 18.00 \\
\hline Andorra & 15.05 & China & 8.06 & Guinea & 43.00 & Liechtenstein & 5.33 & Palau & 35.17 & Suriname & 11.25 \\
\hline Antigua and Barbuda & 18.17 & Comoros & 30.15 & Guyana & 33.31 & Luxembourg & 5.69 & Panama & 6.76 & Sweden & 8.19 \\
\hline Argentina & 13.31 & Congo & 25.85 & Haiti & 27.10 & Macao SAR & 7.92 & Papua New Guinea & 2.86 & Switzerland & 3.50 \\
\hline Armenia & 16.11 & Congo & 39.30 & Holy See & 5.70 & Macedonia & 12.52 & Paraguay & 15.14 & Syria & 23.62 \\
\hline Australia & 5.39 & Costa Rica & 7.94 & Honduras & 10.40 & Madagascar & 12.09 & Peru & 14.54 & Taiwan & 1.04 \\
\hline Austria & 6.97 & Cote d'Ivoire & 30.50 & Hong Kong SAR & 3.96 & Malawi & 12.38 & Philippines & 14.82 & Tajikistan & 14.75 \\
\hline Azerbaijan & 6.35 & Croatia & 5.62 & Hungary & 4.38 & Malaysia & 15.97 & Poland & 6.37 & Tanzania & 11.22 \\
\hline Bahamas & 5.75 & Cuba & 14.17 & Iceland & 5.17 & Maldives & 12.67 & Portugal & 6.67 & Thailand & 6.77 \\
\hline Bahrain & 2.00 & Cyprus & 12.60 & India & 13.10 & Mali & 33.69 & Qatar & 4.57 & Timor-Leste & 18.67 \\
\hline Bangladesh & 24.85 & Czech Republic & 6.34 & Indonesia & 4.78 & Malta & 7.63 & Romania & 12.71 & Togo & 28.60 \\
\hline Barbados & 8.43 & Denmark & 6.59 & Iran & 16.65 & Marshall Islands & 9.50 & Russia & 2.17 & Tonga & 35.73 \\
\hline Belarus & 3.22 & Djibouti & 28.23 & Iraq & 15.06 & Mauritania & 24.81 & Rwanda & 24.28 & Trinidad and Tobago & 5.29 \\
\hline Belgium & 7.08 & Dominica & 28.17 & Ireland & 5.20 & Mauritius & 9.67 & Saint Kitts and Nevis & 21.83 & Tunisia & 16.94 \\
\hline Benin & 26.07 & Ecuador & 17.50 & Italy & 8.21 & Micronesia & 47.17 & Saint Vincent and the Grenadines & 24.17 & Turkmenistan & 12.26 \\
\hline Bhutan & 48.86 & Egypt & 14.90 & Jamaica & 18.41 & Moldova & 13.61 & Samoa & 30.67 & Tuvalu & 22.83 \\
\hline Bolivia & 14.28 & El Salvador & 13.09 & Japan & 4.18 & Monaco & 11.31 & San Marino & 8.92 & Uganda & 17.66 \\
\hline Bosnia and Herzegovina & 5.18 & Equatorial Guinea & 8.10 & Jordan & 12.82 & Mongolia & 21.91 & Sao Tome and Principe & 14.62 & Ukraine & 6.69 \\
\hline Botswana & 7.91 & Eritrea & 27.62 & Kazakhstan & 3.52 & Montenegro & 6.37 & Saudi Arabia & 5.82 & United Arab Emirates & 8.62 \\
\hline Brazil & 10.21 & Estonia & 3.22 & Kenya & 15.08 & Morocco & 23.90 & Senegal & 33.15 & United Kingdom & 4.66 \\
\hline Brunei Darussalam & 6.74 & Ethiopia & 22.35 & Kiribati & 19.33 & Mozambique & 4.28 & Serbia & 7.03 & United States of America & 3.34 \\
\hline Bulgaria & 10.27 & Fiji & 14.86 & Korea (North) & 8.97 & Namibia & 5.42 & Seychelles & 7.95 & Uruguay & 11.05 \\
\hline Burkina Faso & 21.70 & Finland & 5.86 & Korea (South) & 15.15 & Nauru & 32.67 & Sierra Leone & 37.29 & Uzbekistan & 11.80 \\
\hline Burma & 12.29 & France & 8.79 & Kosovo & 24.25 & Nepal & 25.41 & Singapore & 4.89 & Vanuatu & 9.88 \\
\hline Burundi & 28.37 & Gabon & 12.04 & Kuwait & 2.83 & Netherlands & 8.66 & Slovakia & 4.20 & Venezuela & 12.41 \\
\hline Cambodia & 20.11 & Gambia & 44.79 & Kyrgyzstan & 20.38 & New Zealand & 5.00 & Slovenia & 3.85 & Vietnam & 11.82 \\
\hline Cameroon & 32.82 & Georgia & 14.48 & Laos & 22.19 & Nicaragua & 10.63 & Solomon Islands & 7.20 & Yemen & 17.18 \\
\hline Canada & 5.53 & Germany & 6.91 & Latvia & 5.87 & Niger & 26.13 & Somalia & 61.83 & Zambia & 7.80 \\
\hline Cape Verde & 25.67 & Ghana & 37.24 & Lebanon & 10.52 & Nigeria & 37.01 & South Africa & 3.80 & Zimbabwe & 9.06 \\
\hline
\end{tabular}


Table A2: World Passport Ranking

\begin{tabular}{|c|c|c|c|}
\hline \multicolumn{2}{|c|}{ Most Powerful Passports in the World } & \multicolumn{2}{|c|}{ Weakest Passports in the World } \\
\hline Country & Number of visa free entries & Country & Number of visa free entries \\
\hline Germany & 158 & Afghanistan & 24 \\
\hline Sweden & 158 & Pakistan & 27 \\
\hline Finland & 157 & Iraq & 30 \\
\hline France & 157 & Somalia & 31 \\
\hline Switzerland & 157 & Syria & 32 \\
\hline Spain & 157 & Bangladesh & 35 \\
\hline United Kingdom & 157 & Iran & 35 \\
\hline Denmark & 156 & Libya & 35 \\
\hline Italy & 156 & South Sudan & 36 \\
\hline Netherlands & 156 & Ethiopia & 36 \\
\hline Belgium & 156 & Sudan & 36 \\
\hline South Korea & 156 & Palestinian Territories & 38 \\
\hline Norway & 156 & Eritrea & 38 \\
\hline Singapore & 155 & Sri Lanka & 39 \\
\hline Luxembourg & 155 & Congo (Dem. Rep.) & 39 \\
\hline Austria & 155 & Nepal & 40 \\
\hline Portugal & 155 & Lebanon & 40 \\
\hline United States of America & 155 & Kosovo & 41 \\
\hline Greece & 154 & North Korea & 41 \\
\hline Ireland & 154 & Yemen & 42 \\
\hline
\end{tabular}

Notes: Number of visa free entries indicates the number of countries a passport holder can visit without requiring a visa, or can obtain a visa on arrival. Data for passport power rank are taken from https://www.passportindex.org 
Table A3: List of Host Countries in the Sample

\begin{tabular}{llll}
\hline Austria & Lithuania & Belgium & Luxembourg \\
Bulgaria & Malta & Cyprus & Netherlands \\
Czech Rep. & Norway & Denmark & Poland \\
Estonia & Portugal & Finland & Romania \\
France & Slovakia & Germany & Slovenia \\
Greece & Spain & Hungary & Sweden \\
Iceland & Switzerland & Italy & U.K. \\
Latvia & U.S. & & \\
\hline
\end{tabular}


Table A4: List of Origin Countries in the Sample

\begin{tabular}{|c|c|c|c|c|c|}
\hline Afghanistan & CAR & Greece & Lesotho & Norway & Spain \\
\hline Albania & Chad & Grenada & Liberia & Oman & Sri Lanka \\
\hline Algeria & Chile & Guatemala & Libya & Pakistan & Sudan \\
\hline Andorra & China & Guinea & Liechtenstein & Palau & Suriname \\
\hline Angola & Colombia & Guinea-Bissau & Lithuania & Palestinian & Swaziland \\
\hline Antigua and Barbuda & Comoros & Guyana & Luxembourg & Panama & Sweden \\
\hline Argentina & Congo & Haiti & Macao SAR & Papua New Guinea & Switzerland \\
\hline Armenia & Congo (DR) & Holy See & Macedonia & Paraguay & Syria \\
\hline Australia & Costa Rica & Honduras & Madagascar & Peru & Taiwan \\
\hline Austria & Cote d'Ivoire & Hong Kong SAR & Malawi & Philippines & Tajikistan \\
\hline Azerbaijan & Croatia & Hungary & Malaysia & Poland & Tanzania \\
\hline Bahamas & Cuba & Iceland & Maldives & Portugal & Thailand \\
\hline Bahrain & Cyprus & India & Mali & Qatar & Timor-Leste \\
\hline Bangladesh & Czech Republic & Indonesia & Malta & Romania & Togo \\
\hline Barbados & Denmark & Iran & Marshall Islands & Russia & Tonga \\
\hline Belarus & Djibouti & Iraq & Mauritania & Rwanda & Trinidad and Tobago \\
\hline Belgium & Dominica & Ireland & Mauritius & Saint Kitts and Nevis & Tunisia \\
\hline Belize & Dominican Republic & Israel & Mexico & Saint Lucia & Turkey \\
\hline Benin & Ecuador & Italy & Micronesia & Saint Vincent & Turkmenistan \\
\hline Bhutan & Egypt & Jamaica & Moldova & Samoa & Tuvalu \\
\hline Bolivia & El Salvador & Japan & Monaco & San Marino & Uganda \\
\hline Bosnia and Herzegovina & Equatorial Guinea & Jordan & Mongolia & Sao Tome and Principe & Ukraine \\
\hline Botswana & Eritrea & Kazakhstan & Montenegro & Saudi Arabia & UAE \\
\hline Brazil & Estonia & Kenya & Morocco & Senegal & UK \\
\hline Brunei Darussalam & Ethiopia & Kiribati & Mozambique & Serbia & USA \\
\hline Bulgaria & Fiji & Korea (North) & Namibia & Seychelles & Uruguay \\
\hline Burkina Faso & Finland & Korea (South) & Nauru & Sierra Leone & Uzbekistan \\
\hline Burma & France & Kosovo & Nepal & Singapore & Vanuatu \\
\hline Burundi & Gabon & Kuwait & Netherlands & Slovakia & Venezuela \\
\hline Cambodia & Gambia & Kyrgyzstan & New Zealand & Slovenia & Vietnam \\
\hline Cameroon & Georgia & Laos & Nicaragua & Solomon Islands & Yemen \\
\hline Canada & Germany & Latvia & Niger & Somalia & Zambia \\
\hline Cape Verde & Ghana & Lebanon & Nigeria & South Africa & Zimbabwe \\
\hline
\end{tabular}




\section{References}

Acemoglu, D. and Cantoni, D. (2011). The consequences of radical reform: The french revolution. American Economic Review, 101:3286-3307.

Acemoglu, D. and Johnson, S. (2005). Unbundling institutions. Journal of Political Economy, 113(5):949-995.

Acemoglu, D., Johnson, S., and Robinson, J. A. (2002). Reversal of fortune: Geography and institutions in the making of the modern world income distribution. Quarterly journal of economics, pages 1231-1294.

Acemoglu, D., Johnson, S., Robinson, J. A., and Yared, P. (2005). From education to democracy? American Economic Review, pages 44-49.

Acemoglu, D. and Robinson, A. (2001). The colonial origins of comparative development: An empirical investigation. The American Economic Review, 91(5):1369-1401.

Acemoglu, D. and Robinson, J. A. (2000). Political losers as a barrier to economic development. The American Economic Review, 90(2):126-130.

Agrawal, A., Cockburn, I., and McHale, J. (2006). Gone but not forgotten: knowledge flows, labor mobility, and enduring social relationships. Journal of Economic Geography, 6(5):571-591.

Almeida, P. and Kogut, B. (1999). Localization of knowledge and the mobility of engineers in regional networks. Management science, 45(7):905-917.

Andersen, T. B. and Dalgaard, C.-J. (2011). Flows of people, flows of ideas, and the inequality of nations. Journal of Economic Growth, 16(1):1-32.

Arellano, M. and Bond, S. (1991). Some tests of specification for panel data: Monte carlo evidence and an application to employment equations. The review of economic studies, $58(2): 277-297$. 
Arrow, K. J. (1969). Classificatory notes on the production and transmission of technological knowledge. The American Economic Review, 59(2):29-35.

Barnett, G. A. and Wu, R. Y. (1995). The international student exchange network: 1970 \& 1989. Higher Education, 30(4):353-368.

Barro, R. J. (1999). Determinants of democracy. Journal of Political economy, 107(S6):S158S183.

Batista, C. and Vicente, P. C. (2011). Do migrants improve governance at home? evidence from a voting experiment. The World Bank Economic Review, page lhr009.

Beine, M., Docquier, F., and Rapoport, H. (2001). Brain drain and economic growth: theory and evidence. Journal of development economics, 64(1):275-289.

Bergerhoff, J., Borghans, L., Seegers, P. K., and Van Veen, T. (2013). International education and economic growth. IZA Journal of European Labor Studies, 2(1):1-13.

Bergh, A., Mirkina, I., and Nilsson, T. (2014). Globalization and institutional quality a panel data analysis. Oxford Development Studies, 42(3):365-394.

Caselli, F. (2005). Accounting for cross-country income differences. Handbook of economic growth, 1:679-741.

Caselli, F., Esquivel, G., and Lefort, F. (1996). Reopening the convergence debate: a new look at cross-country growth empirics. Journal of economic growth, 1(3):363-389.

Coe, D. T. and Helpman, E. (1995). International r\&d spillovers. European economic review, $39(5): 859-887$.

Cristea, A. D. (2011). Buyer-seller relationships in international trade: Evidence from us states' exports and business-class travel. Journal of International Economics, 84(2):207220.

Dawson, J. W. (1998). Institutions, investment, and growth: New cross-country and panel data evidence. Economic inquiry, 36(4):603-619. 
De La Potterie, B. V. P. and Lichtenberg, F. (2001). Does foreign direct investment transfer technology across borders? Review of Economics and Statistics, 83(3):490-497.

Demsetz, H. (1967). Toward a theory of property rights. American Economic Review, $57(2): 347-359$.

Diamond, J. (1999). Guns, germs, and steel: The fates of human societies. WW Norton and Company, New York.

Docquier, F., Lodigiani, E., Rapoport, H., Schiff, M., et al. (2010). Emigration and the quality of home country institutions. Catholic University of Louvain, University of Luxembourg, Harvard University, and World Bank.

Docquier, F. and Rapoport, H. (2012). Globalization, brain drain, and development. Journal of Economic Literature, 50(3):681-730.

Dos Santos, M. D. and Postel-Vinay, F. (2003). Migration as a source of growth: the perspective of a developing country. Journal of Population Economics, 16(1):161-175.

Dowrick, S. and Tani, M. (2011). International business visits and the technology frontier. Economics Letters, 110(3):209-212.

Durand, J., Parrado, E. A., and Massey, D. S. (1996). Migradollars and development: A reconsideration of the mexican case. International Migration Review, pages 423-444.

Dustmann, C., Fadlon, I., and Weiss, Y. (2011). Return migration, human capital accumulation and the brain drain. Journal of Development Economics, 95(1):58-67.

Dutta, N., Leeson, P. T., and Williamson, C. R. (2013). The amplification effect: Foreign aid's impact on political institutions. Kyklos, 66(2):208-228.

Easterly, W. and Levine, R. (2003). Tropics, germs, and crops: how endowments influence economic development. Journal of monetary economics, 50(1):3-39.

Eaton, J. and Kortum, S. (2002). Technology, geography, and trade. Econometrica, 70(5):1741-1779. 
Edmond, C. (2001). Some panel cointegration models of international r\&d spillovers. Journal of Macroeconomics, 23(2):241-260.

Elert, N. and Halvarsson, D. (2012). Economic freedom and institutional convergence. Ratio Institute Working Paper No. 196.

Engelbrecht, H.-J. (1997). International r\&d spillovers, human capital and productivity in oecd economies: An empirical investigation. European Economic Review, 41(8):1479-1488.

Feenstra, R. C., Inklaar, R., and Timmer, M. P. (2015). The next generation of the penn world table. The American Economic Review, 105(10):3150-3182.

Foster, A. D. and Rosenzweig, M. R. (1995). Learning by doing and learning from others: Human capital and technical change in agriculture. Journal of political Economy, pages 1176-1209.

Frankel, J. A. and Romer, D. (1999). Does trade cause growth? American economic review, pages 379-399.

Gallup, J. L., Sachs, J. D., and Mellinger, A. D. (1999). Geography and economic development. International regional science review, 22(2):179-232.

Glaeser, E. L., La Porta, R., Lopez-de Silanes, F., and Shleifer, A. (2004). Do institutions cause growth? Journal of economic Growth, 9(3):271-303.

Glaeser, E. L., Ponzetto, G. A., and Shleifer, A. (2007). Why does democracy need education? Journal of economic growth, 12(2):77-99.

Guild, E. (2009). Security and Migration in the 21st Century. Polity.

Guiso, L., Sapienza, P., and Zingales, L. (2009). Cultural biases in economic exchange? The Quarterly Journal of Economics, 124(3):1095-1131.

Hall, J. (2016). Institutional convergence: Exit or voice? Journal of Economics and Finance, 40(4):829-840. 
Hall, R. E. and Jones, C. I. (1999). Why do some countries produce so much more output per worker than others? The Quarterly Journal of Economics, 114(1):83-116.

Heckelman, J. C. and Young, A. T. (2014). How global is globalization? West Virginia Working Paper No. 14-08.

Hildebrandt, N., McKenzie, D. J., Esquivel, G., and Schargrodsky, E. (2005). The effects of migration on child health in mexico [with comments]. Economia, pages 257-289.

Hobolth, M. (2012). Researching mobility barriers: The european visa database. Technical report, LSE Migration Studies Unit Working Paper Series. No. 3/2012. London: London School of Economics and Political Science.

Hovhannisyan, N. and Keller, W. (2015). International business travel: an engine of innovation? Journal of Economic Growth, 20(1):75-104.

Howitt, P. (2000). Endogenous growth and cross-country income differences. American Economic Review, pages 829-846.

Inklaar, R. and Timmer, M. (2013). Capital, labor and tfp in pwt8. 0.

Irwin, D. A. and Klenow, P. J. (1994). Learning-by-doing spillovers in the semiconductor industry. Journal of political Economy, pages 1200-1227.

Jones, B. F., Olken, B. A., et al. (2005). Do leaders matter? national leadership and growth since world war ii. The Quarterly Journal of Economics, 120(3):835-864.

Keller, W. (1998). Are international r\&d spillovers trade-related?: Analyzing spillovers among randomly matched trade partners. European Economic Review, 42(8):1469-1481.

Keller, W. (2004). International technology diffusion. Journal of Economic Literature, 42:752-782.

Kim, J. (1998). Economic analysis of foreign education and students abroad. Journal of Development Economics, 56(2):337-365. 
Kim, J., Lee, S. J., and Marschke, G. (2009). International knowledge flows: evidence from an inventor-firm matched data set. In Science and Engineering Careers in the United States: An Analysis of Markets and Employment, pages 321-348. University of Chicago Press.

Klenow, P. and Rodriguez-Clare, A. (1997). The neoclassical revival in growth economics: Has it gone too far? In NBER Macroeconomics Annual 1997, Volume 12, pages 73-114. MIT Press.

Klenow, P. J. and Rodriguez-Clare, A. (2005). Externalities and growth. Handbook of economic growth, 1:817-861.

Knack, S. and Keefer, P. (1995). Institutions and economic performance: Cross-country tests using alternative institutional measures. Economics $\&$ Politics, 7(3):207-227.

La Porta, R., Lopez-de Silanes, F., Shleifer, A., and Vishny, R. (1999). The quality of government. Journal of Law, Economics, and organization, 15(1):222-279.

La Porta, R., Lopez-de Silanes, F., Shleifer, A., and Vishny, R. W. (1998). Law and finance. Journal of Political Economy, 106(6).

Lawson, R. A. and Lemke, J. S. (2012). Travel visas. Public Choice, 153(1-2):17-36.

Lawson, R. A. and Roychoudhury, S. (2013). Do travel visa requirements impede tourist travel? Journal of Economics and Finance, pages 1-12.

Le, T. (2008). Brain drain or brain circulation: Evidence from oecd's international migration and r\&d spillovers. Scottish Journal of Political Economy, 55(5):618-636.

Le, T. (2010). Are student flows a significant channel of r\&d spillovers from the north to the south? Economics Letters, 107(3):315-317.

Le, T. (2012). R\&d spillovers through student flows, institutions, and economic growth: What can we learn from african countries? Scottish Journal of Political Economy, $59(1): 115-130$. 
Lee, G. (2006). The effectiveness of international knowledge spillover channels. European Economic Review, 50(8):2075-2088.

Leeson, P. T. (2008). Media freedom, political knowledge, and participation. Journal of Economic Perspectives, 22(2):155-155.

Leeson, P. T. and Dean, A. M. (2009). The democratic domino theory: An empirical investigation. American Journal of Political Science, 53(3):533-551.

Li, X., McHale, J., and Zhou, X. (2016). Does brain drain lead to institutional gain? The World Economy.

Lucas, Robert E., J. (1988). On the mechanics of economic development. Journal of Monetary Economics, 22(1):3 - 42 .

Melitz, J. and Toubal, F. (2014). Native language, spoken language, translation and trade. Journal of International Economics, 93(2):351-363.

Mountford, A. (1997). Can a brain drain be good for growth in the source economy? Journal of development economics, 53(2):287-303.

Neumayer, E. (2010). Visa restrictions and bilateral travel. The professional geographer, $62(2): 171-181$.

Neumayer, E. (2011). On the detrimental impact of visa restrictions on bilateral trade and foreign direct investment. Applied geography, 31(3):901-907.

North, D. C. (1990). Institutions, institutional change and economic performance. Cambridge university press.

Oettl, A. and Agrawal, A. (2008). International labor mobility and knowledge flow externalities. Journal of International Business Studies, 39(8):1242-1260.

Parente, S. L. and Prescott, E. C. (1999). Monopoly rights: A barrier to riches. American Economic Review, pages 1216-1233. 
Park, J. (2004). International student flows and r\&d spillovers. Economics Letters, 82(3):315320.

Pfutze, T. (2012). Does migration promote democratization? evidence from the mexican transition. Journal of Comparative Economics, 40(2):159-175.

Power, P. F. (1969). Gandhi in south africa. The Journal of Modern African Studies, $7(03): 441-455$.

Przeworski, A. (2005). Democracy as an equilibrium. Public Choice, 123(3-4):253-273.

Rodrik, D., Subramanian, A., and Trebbi, F. (2004). Institutions rule: The primacy of institutions over geography and integration in economic development. Journal of Economic Growth, 9(2):131-165.

Sheehan, K. M. and Young, A. T. (2015). It's a small world after all: Internet access and institutional quality. Contemporary Economic Policy, 33(4):649-667.

Sobel, R. S. and Coyne, C. J. (2011). Cointegrating institutions: The time-series properties of country institutional measures. Journal of Law and Economics, 54(1):111-134.

Spilimbergo, A. (2009). Democracy and foreign education. The American Economic Review, pages $528-543$.

Spolaore, E. and Wacziarg, R. (2009). The diffusion of development. The Quarterly Journal of Economics, 124(2):469-529.

Tani, M. and Joyeux, R. (2013). Do business visits cause productivity growth? IZA Discussion Paper No. $782 \%$.

World Tourism Organization (2014). UNWTO Tourism Highlights: 2013 Edition. World Tourism Organization, Madrid. 